\title{
Laboratório de geração de classificadores de seqüências
}

\author{
ARIANE Machado Lima de Oliveira
}

\author{
DISSERTAÇÃO APRESENTADA \\ $A O$ \\ INSTITUTO DE MATEMÁTICA E ESTATÍSTICA \\ DA \\ UNIVERSIDADE DE SÃO PAULO \\ PARA \\ OBTENÇÃO DO GRAU DE MESTRE \\ EM \\ CIÊNCIA DA COMPUTAÇÃO
}

Curso: Mestrado em Ciência da Computação

Área de Concentração: Ciência da Computação

Orientador: Prof. Dr. Alan Mitchell Durham

Durante a elaboração deste trabalho a autora recebeu apoio financeiro do CNPq

— São Paulo, SP — Julho de 2002 - 


\section{Laboratório de geração \\ de classificadores de seqüências}

Este exemplar corresponde à redação final da dissertação devidamente corrigida e defendida por Ariane Machado Lima de Oliveira e aprovada pela comissão julgadora.

São Paulo, Julho de 2002

\section{Banca examinadora:}

Prof. Dr. Alan Mitchell Durham (orientador) IME-USP

Prof. Dr. Paulo José da Silva e Silva IME-USP

Prof. Dr. João José Neto POLI-USP 
Aos meus pais

João e Yolanda. 



\section{Agradecimentos}

Em primeiro lugar, gostaria de agradecer a Deus, sem o qual trabalho nenhum teria importância para mim. Paizão, obrigada pela paz que o Senhor tem me dado, principalmente durante momentos muito difíceis que enfrentei neste mestrado.

Um agradecimento especial ao meu orientador, professor Alan Mitchell Durham, pela disposição em discutir dúvidas e certezas, pelo tempo gasto em correções de textos, pelo apoio dado quando faltam as forças, pelo relacionamento descontraído, e principalmente por ter me influenciado a trabalhar com bioinformática.

Agradeço ao professor Júnior Barrera, que concebeu a idéia deste trabalho e tornou possível sua realização. Também ao Caetano, seu aluno, que implementou um dos programas utilizados neste trabalho.

Agradecimentos aos meus pais João e Yolanda, que me deram sempre o amor e apoio necessários para eu chegar até aqui. Amo vocês!

Aos meus irmãos Áquila (Caiá) e Marcus Vinicius (Bão, Gão, Vini, Negão, Vini Bandana, ...), que sempre torcem pelo meu sucesso... e pelo meu descanso!

Ao meu querido Fernando, que tem me dado o privilégio de tê-lo sempre ao meu lado apoiando, inspirando e compartilhando cansaços e alegrias. Te amo Fê!

Às minhas cunhadas Cibele e Andréa, que não viam a hora de eu terminar essa "trabalheira". Déia: "KBEI!!!"

Aos amigos do IME, que são muitos, ou seja, o IME inteiro! Para citar alguns representantes, o Daniel que trabalha comigo, o Said que cedeu gentilmente uma figura sua para este trabalho, Kátia, o pessoal do BioInfo que passam o dia ouvindo minhas "perguntas que só eu faço"e ainda me ajudam a responder, amigos antigos como Jorge (meu consultor Java e C++), Bob (consultor latex), Lucy, Marcelo Brito, Bianka (consultora financeira), Sandro (meu irmão do coração, que me dava bombinha energética para terminar o texto), seu João, professor Kunio e muitos e muitos outros. Também àqueles que não estão mais no IME, como Ricardo e Marquinhos. Aos funcionários que sempre me ajudaram no que podiam, como o pessoal dos Serviços Gerais, do áudio visual (aí Nilsão!), da secretaria da CPG, Carlão da gráfica, etc. 
À minha amigona Selma, que nunca sai do meu lado, rindo ou chorando, animando-me sempre! Valeu, Selminha!!!

Ao professor Alfredo, que foi meu chefe e amigo no CEC, e que me deu um grande apoio durante o tempo em que trabalhei lá.

Ao professor Hernando, que tive a oportunidade de conhecer e admirar, e que tem tido paciência de esperar eu terminar meus trabalhos... Também à galera do ICB, que tem me recebido de braços abertos.

Ap professor Arthur Gruber, da FMVZ, que colocou à disposição o servidor de seu laboratório para execução de testes contidos neste trabalho.

Aos amigos "normais"(extra-IME), como Ivone, Sílvia e Júlio, Simone... (que saudades de vocês!!!).

Puxa, realmente é bom ter tantos amigos assim. Isso sim é minha maior conquista...

BEIJOS A TODOS!!!

Ariane Machado Lima 


\title{
Resumo
}

Esta dissertação apresenta um arcabouço para implementação de algoritmos de inferência de gramáticas estocásticas. Este arcabouço inclui suporte de software para a geração automática de classificadores de seqüências. O objetivo final do sistema é ser usado no desenvolvimento de novos classificadores para seqüências genéticas.

\begin{abstract}
This thesis presents a framework for the implementation of inference algorithms for stochastic grammars. This framework includes supporting software for the automatic generation of classifiers for sequences. The final goal of the system is to be used in the development of new classifiers for genetic sequences.
\end{abstract}





\section{Índice}

1 Introdução 1

1.1 Contexto do trabalho . . . . . . . . . . . . . . . . . 1

1.2 Organização deste documento . . . . . . . . . . . . . . . . 2

2 Conceitos Preliminares 3

2.1 Um pouco de biologia molecular . . . . . . . . . . . . . . . . 3

2.1 .1 A molécula de DNA . . . . . . . . . . . . . . . . 3

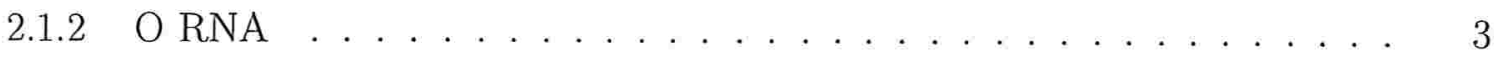

2.1.3 A síntese de proteínas . . . . . . . . . . . . . . 5 5

2.1.4 Similaridades entre seqüências . . . . . . . . . . . . . . 5

2.1 .5 Mutações ......................... 5

2.2 Aprendizado computacional . . . . . . . . . . . . . . . 6

2.3 Noções preliminares de linguagens formais . . . . . . . . . . . . . 8

2.4 Aplicações em bioseqüências . . . . . . . . . . . . . . . . . . . . 13

2.4.1 Gramáticas estocásticas podem ser utilizadas . . . . . . . . . . 14

2.4.2 Gramáticas regulares podem ser utilizadas . . . . . . . . . . . . 15

2.4.3 A linguagem do DNA e do RNA é no mínimo livre de contexto . . . . 15

2.4.4 A linguagem do DNA e do RNA é sensível ao contexto . . . . . . . . 19

2.5 Classificação de Bayes . . . . . . . . . . . . . . . . . . . . 20

2.6 Aprendizado de classificadores . . . . . . . . . . . . . . . . . . . . . . 21 
3.1 Identificação no limite . . . . . . . . . . . . . . . . . . . 24

3.2 Métodos de busca . . . . . . . . . . . . . . . . . . . 25

3.3 Estratégias de inferência de GLCs . . . . . . . . . . . . . . . . . 25

3.3.1 Auxílio de oráculos . . . . . . . . . . . . . . . . . 26

3.3.2 Inferência a partir de exemplos estruturais . . . . . . . . . . . . 26

3.3.3 Inferência de subclasses de GLCs . . . . . . . . . . . . . . . . . 28

3.4 Algoritmos implementados para o módulo de inferência . . . . . . . . . . . . 31

3.4 .1 Algoritmo para inferência de gramáticas reversíveis . . . . . . . . . 32

3.4.2 Algoritmo para inferência de gramáticas tipo-inversíveis . . . . . . . . 35

4 Estimação de parâmetros de GLCEs $\quad 39$

4.1 Estimação de passo único . . . . . . . . . . . . . . . . . . . 40

4.2 Tree Grammar Reestimator . . . . . . . . . . . . . . . . . . . . . . 41

$4.2 .1 \quad$ Algoritmos EM . . . . . . . . . . . . . . . . 41

4.2 .2 O algoritmo TGR . . . . . . . . . . . . . . 42

4.3 Observações sobre os estimadores . . . . . . . . . . . . . . 47

5 Implementação do arcabouço $\quad 49$

5.1 Arquitetura básica . . . . . . . . . . . . . . . . . . . . 49

5.2 Algoritmos de aprendizado . . . . . . . . . . . . . . . . 52

5.2 .1 Inferidor de Gramáticas (IG) . . . . . . . . . . . . . . . . 53

5.2 .2 Estimador de Probabilidades (EP) . . . . . . . . . . . . . . 59

5.3 Módulo de suporte a implementações . . . . . . . . . . . . . . . . . . 60

5.3 .1 Streams ............................ 62

5.3 .2 Grammar ......................... 66

5.3 .3 TreeAutomaton ...................... 69

5.3 .4 Trie ............................. 71

5.3.5 EarleyParser. . . . . . . . . . . . . . . . . 72

5.3.6 Gerador de Analisadores Sintáticos (GAna) . . . . . . . . . . . . 73

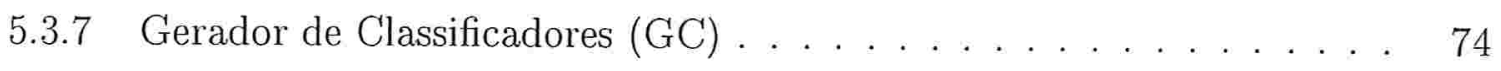

5.4 Módulo de suporte à composição e testes dos algoritmos . . . . . . . . . . . 75 
6 Avaliação preliminar dos algoritmos $\quad 79$

6.1 Metodologia de testes . . . . . . . . . . . . . . . . . . 80

6.1 .1 Informações avaliadas . . . . . . . . . . . . . . . . . . . . 80

6.1 .2 Utilização de dados simulados . . . . . . . . . . . . . . . . . 81

6.1 .3 Escolha das gramáticas . . . . . . . . . . . . . . . . . 83

6.1 .4 Repetição de testes . . . . . . . . . . . . . . . . . . . 84

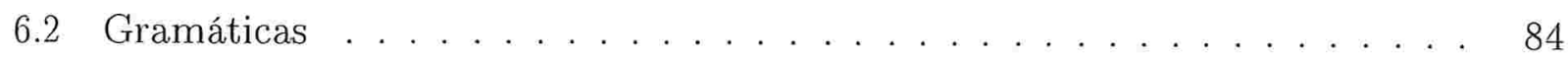

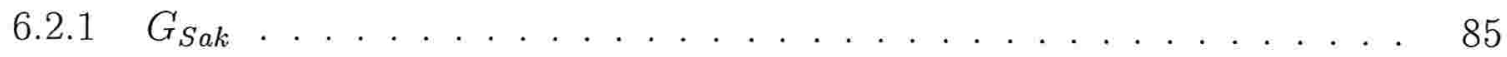

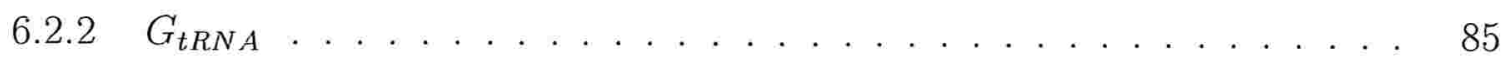

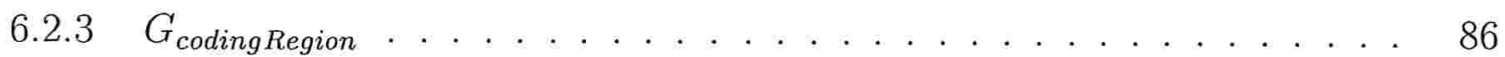

$6.2 .4 G_{\text {stem-loop } \ldots \ldots \ldots \ldots \ldots \ldots \ldots} . \ldots \ldots \ldots$

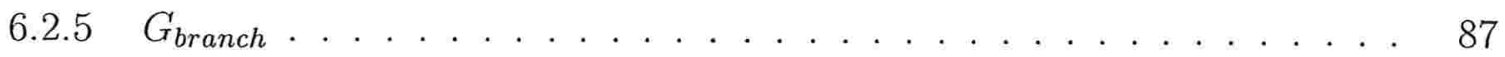

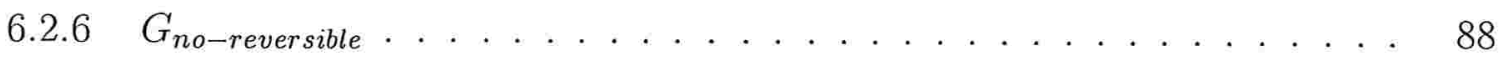

6.3 Análise dos inferidores gramaticais . . . . . . . . . . . . . . . 88

6.3.1 Análise dos resultados de $G_{S a k}$ e $G_{\text {codingRegion }}$. . . . . . . . . . . . . . 89

6.3.2 Análise dos resultados das demais gramáticas . . . . . . . . . . . . . 94

6.4 Análise dos estimadores de probabilidades . . . . . . . . . . . . . . . . 98

7 Conclusão 103

7.1 Principais resultados obtidos . . . . . . . . . . . . . . . 103

7.2 Trabalhos futuros . . . . . . . . . . . . . . . . . . . 104

$\begin{array}{lr}\text { A Gramática } g_{t R N A} & 109\end{array}$ 



\section{Lista de Figuras}

2.1 Molécula de DNA . . . . . . . . . . . . . . . . . . . . 4

2.2 Alguns tipos de mutações $\ldots \ldots \ldots \ldots \ldots$

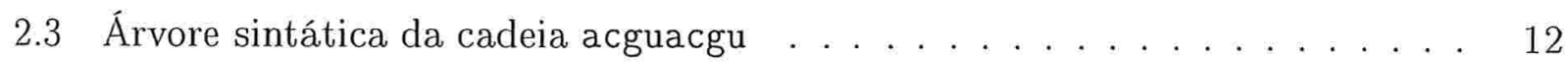

2.4 Segunda árvore sintática da cadeia acguacgu . . . . . . . . . . . . . . . 13

2.5 Estrutura hairpin descrita por $G_{\text {hairpin }} \ldots \ldots \ldots \ldots \ldots \ldots$

2.6 Estrutura de laço descrita por $G_{\text {stem-loop }} \ldots \ldots \ldots \ldots \ldots \ldots$

2.7 Estrutura de ramificação descrita por $G_{\text {branch }} \ldots \ldots \ldots \ldots \ldots$

2.8 À esquerda a estrutura secundária segundo a derivação 1. À direita a a estrutura secundária segundo a derivação $2 \ldots \ldots \ldots \ldots \ldots$

2.9 Dependências cruzadas de uma repetição . . . . . . . . . . . . . . . . . 19

2.10 Estrutura de um pseudo-nó . . . . . . . . . . . . . . . . . . . . . 19

2.11 Dependências cruzadas de um pseudo-nó "esticado" . . . . . . . . . . . . . 20

2.12 Curvas de probabilidade . . . . . . . . . . . . . . . . . . . 21

2.13 Gerando classificadores . . . . . . . . . . . . . . . . . . . . . . 22

3.1 Esqueleto de uma frase . . . . . . . . . . . . . . . . 27

3.2 Ramificação em uma estrutura secundária de RNA . . . . . . . . . . . . 29

3.3 Laço em uma estrutura secundária de RNA . . . . . . . . . . . . . 30

3.4 À esquerda um autômato a árvore com partição inicial. À direita o mesmo autômato a árvore após o agrupamento dos blocos $b_{1}$ e $b_{2} \ldots \ldots \ldots 32$

3.5 Correspondência entre um estado $s$ de um autômato a árvore e um caminho da raiz ao nó $n$ em uma trie equivalente . . . . . . . . . . 35

3.6 Um autômato, sua trie correspondente e sua trie com nova rotulação . . . . . 37 
4.1 Árvore da cadeia $((\mathrm{a}(\mathrm{cg}) \mathrm{u})(\mathrm{a}(\mathrm{cg}) \mathrm{u})) \ldots \ldots . \ldots . \ldots . \ldots 42$

$4.2 \AA \grave{A}$ esquerda $t / 3$ e à direita $t \backslash 3 \ldots \ldots \ldots \ldots \ldots$

5.1 Processo de aprendizado de uma gramática estocástica . . . . . . . . . . . 53

5.2 UML simplificada de IG . . . . . . . . . . . . . . . . . . . . 53

5.3 UML simplificada de EP . . . . . . . . . . . . . . . . . . . . . . . . 59

5.4 UML de IG com os componentes de suporte . . . . . . . . . . . . . . . . . 61

5.5 UML de EP com os componentes de suporte . . . . . . . . . . . . . . . . 62

5.6 Modelagem de InputStream . . . . . . . . . . . . . . . . . . . 63

5.7 Modelagem de OutputStream . . . . . . . . . . . . . . . 65

5.8 Modelagem de Grammar . . . . . . . . . . . . . . . . . . . . . 66

5.9 UML simplificada de TreeAutomaton . . . . . . . . . . . . . . . . . 70

5.10 Classes envolvidas na modelagem de Trie . . . . . . . . . . . . . . . 71

5.11 UML simplificada de EarleyParser . . . . . . . . . . . . . . . . . . . 73

5.12 Classes do componente GAna . . . . . . . . . . . . . . . . 75

6.1 Quatro modelos de classificadores . . . . . . . . . . . . . . 82

6.2 Falsos negativos de $G_{S a k}$ utilizando $I G_{R T}$ e $I G_{\text {Makinen }} \ldots \ldots \ldots \ldots$. . . . . . . 89

6.3 Número de produções de $G_{S a k}$ utilizando $I G_{R T}$ e $I G_{\text {Makinen }} \quad \ldots \ldots$. . . . . . 90

6.4 Número de produções de $G_{\text {Sak }}$ utilizando $I G_{\text {Makinen }} \ldots \ldots$. . . . . . . . . 90

6.5 Falsos negativos de $G_{\text {codingRegion }}$ utilizando $I G_{R T}$ e $I G_{\text {Makinen }} \ldots \ldots$. . . . . . 91

6.6 Falsos negativos de $G_{\text {codingRegion }}$ utilizando $I G_{\text {Makinen }} \ldots \ldots \ldots$. . . . . . . 91

6.7 Número de produções de $G_{\text {codingRegion }}$ utilizando $I G_{R T}$ e $I G_{\text {Makinen }} \ldots \ldots$. . . 92

6.8 Número de produções de $G_{\text {codingRegion }}$ utilizando $I G_{\text {Makinen }}$. . . . . . . . . . . 92

6.9 Número de produções de $G_{\text {stem-loop }}$ utilizando $I G_{R T}$ e $I G_{\text {Makinen }}$. . . . . . . . 94

6.10 Número de produções de $G_{\text {stem-loop }}$ utilizando $I G_{\text {Makinen }} \ldots \ldots$. . . . . . . . . 94

6.11 Número de produções de $G_{n o-\text { reversible }}$ utilizando $I G_{R T}$ e $I G_{\text {Makinen }} \ldots \ldots 5$

6.12 Número de produções de $G_{n o-\text { reversible }}$ utilizando $I G_{\text {Makinen }} \ldots \ldots$. . . . . . 95

6.13 Número de produções de $G_{\text {branch }}$ utilizando $I G_{R T}$ e $I G_{\text {Makinen }} \ldots \ldots$. . . . . . 96

6.14 Número de produções de $G_{b r a n c h}$ utilizando $I G_{\text {Makinen }} \ldots \ldots$. . . . . . . . . 96

6.15 Número de produções de $G_{t R N A}$ utilizando $I G_{R T}$ e $I G_{\text {Makinen }} \ldots \ldots$. . . . . . 97

6.16 Número de produções de $G_{t R N A}$ utilizando $I G_{\text {Makinen }} \ldots \ldots$. . . . . . . . 97

6.17 Erro médio relativo das probabilidades de $G_{\text {Sak }} \quad \ldots \ldots$. . . . . . . . . . 99 
6.18 Erro médio relativo das probabilidades de $G_{\text {codingRegion }} \quad \ldots \ldots$. . . . . . . . 99

6.19 Erro médio relativo das probabilidades de $G_{S a k} \ldots \ldots$. . . . . . . . . . 100

6.20 Erro médio relativo das probabilidades de $G_{\text {codingRegion }} \ldots \ldots$. . . . . . . 100 



\section{Lista de Tabelas}

5.1 Primeira fase de execuções de $I G_{R T}$ para $G_{t R N A} \ldots \ldots \ldots \ldots$

5.2 Segunda fase de execuções de $I G_{R T}$ para $G_{t R N A} \ldots \ldots \ldots \ldots \ldots$

5.3 Terceira fase de execuções de $I G_{R T}$ para $G_{t R N A} \ldots \ldots \ldots \ldots$ 



\section{Introdução}

\subsection{Contexto do trabalho}

Durante os últimos anos, uma das grandes preocupações dos biólogos tem sido conseguir seqüenciar códigos genéticos. Atualmente, há uma grande quantidade de genomas já seqüenciados [Mou00], incluindo o próprio genoma humano. De posse dessas novas informações, o foco científico está se voltando também para a análise dessas sequiências. Como o volume de dados é gigantesco (o genoma humano completo, por exemplo, é formado por uma seqüência de aproximadamente 3 bilhões de caracteres [DOE92]), faz-se necessário um apoio computacional que auxilie seu gerenciamento e análise. Dessa relação entre os problemas biológicos e a demanda de ferramentas computacionais que auxiliem suas resoluções, nasceu a área interdisciplinar conhecida como biologia molecular computacional, na qual este trabalho se insere.

Este trabalho está vinculado ao projeto $\mathrm{CAGE}^{1}$ (Cooperation for Analysis of Gene Expression), que une esforços do Instituto de Química e do Instituto de Matemática e Estatística da Universidade de São Paulo com o objetivo de estudar os mecanismos de expressão gênica. Uma das linhas de pesquisa é a classificação de seqüências, que visa analisar trechos de DNA e RNA seqüenciados e armazenados em bases de dados. Essa análise será feita através de métodos que agregam esses trechos seqüenciados em famílias (clustering). Partindo de conjuntos de seqüências que conhecidamente são semelhantes deseja-se caracterizar cada conjunto como uma família de seqüências. Essa caracterização poderá então ser usada para

\footnotetext{
${ }^{1}$ Para mais informações sobre o projeto CAGE, consulte sua página internet no endereço http://www.vision.ime.usp.br/ cage
} 
buscar nas bases de dados outras seqüências similares. Os resultados dessas buscas poderão levantar hipóteses sobre seqüências de classificação desconhecida, chamando a atenção para uma investigação bioquímica.

A fim de realizar tal tarefa, deseja-se gerar classificadores de seqüências biológicas a partir de grupos de seqüências similares. Este trabalho sugere a aplicação da teoria de linguagens formais para caracterizar essas famílias de seqüências através de gramáticas e a aplicação da teoria de aprendizado computacional para produzir os classificadores.

A fim de buscar classificadores eficientes, é necessário realizar pesquisas sobre a aplicação dos algoritmos de aprendizado de gramáticas no processo de geração. Visando facilitar essa pesquisa, este trabalho desenvolve um arcabouço ${ }^{2}$ modular para geração automática desses classificadores, proporcionando um laboratório de implementação e testes.

A fim de realizar uma avaliação preliminar da aplicabilidade do aprendizado de gramáticas na classificação de seqüências biológicas, foram implementados e testados alguns algoritmos relacionados com esta área. Durante a implementação de um deles, encontramos erros em sua descrição: erro algorítmico, consumo excessivo de memória e alto tempo de execução. Corrigidas essas falhas, o tempo de execução da nova implementação chegou a diminuir em $0.04 \%$ do tempo gasto pela implementação original.

\subsection{Organização deste documento}

O capítulo 2 apresenta conceitos preliminares de aprendizado computacional, biologia molecular e linguagens formais. Mostra também como diferentes classes gramaticais podem modelar famílias de seqüências genéticas. O capítulo 3 apresenta algumas técnicas de aprendizado de gramáticas. O capítulo 4 trata da aplicação de métodos estatísticos no aprendizado dessas gramáticas. O capítulo 5 descreve a arquitetura do arcabouço. O capítulo 6 traz os resultados de testes dos classificadores gerados a partir dos algoritmos implementados. Por último, o capítulo 7 apresenta as conclusões deste trabalho e trabalhos futuros.

\footnotetext{
${ }^{2}$ Um outro termo para arcabouço é framework. Apesar do último ser mais comum, foi empregado o termo em português.
} 


\section{Conceitos Preliminares}

\subsection{Um pouco de biologia molecular}

\subsubsection{A molécula de DNA}

O DNA, ácido desoxirribonucleico, é uma macromolécula formada de várias unidades menores chamadas nucleotídeos. Os nucleotídeos diferenciam-se pelo tipo de base nitrogenada que possuem: adenina, guanina, citosina ou timina [Lop91, JS90].

A estrutura da molécula de DNA é formada por duas fitas enroladas ao longo de um eixo, como mostra a figura ${ }^{1} 2.1$. Cada fita é composta por uma seqüência linear de nucleotídeos. As duas fitas dispõem-se de modo invertido ${ }^{2}$, havendo ligações (chamadas pontes de hidrogênio) entre bases específicas: a (adenina) liga-se com $t$ (timina) e g (guanina) liga-se com c (citosina).

O comprimento de uma molécula de DNA é medido pelo número de bases de uma fita. O genoma humano possui aproximadamente 3 bilhões de bases.

\subsubsection{O RNA}

Outra macromécula com importantes funções genéticas é o ácido ribonucleico, o RNA. Suas bases nitrogenadas são a adenina, a guanina e a citosina encontradas também no DNA, e a uracila.

\footnotetext{
${ }^{1}$ Figura extraída de [Adi00].

${ }^{2}$ Cada fita de DNA tem duas extremidades livres, uma chamada de 3' e a outra de 5', numa alusão aos átomos de carbono que ficam livres no açúcar que compõe cada nucleotídeo. A convenção adotada é escrever a seqüência do DNA no sentido $5^{\prime} \rightarrow$ 3'. A fita oposta estará no sentido inverso. [MS94]
} 

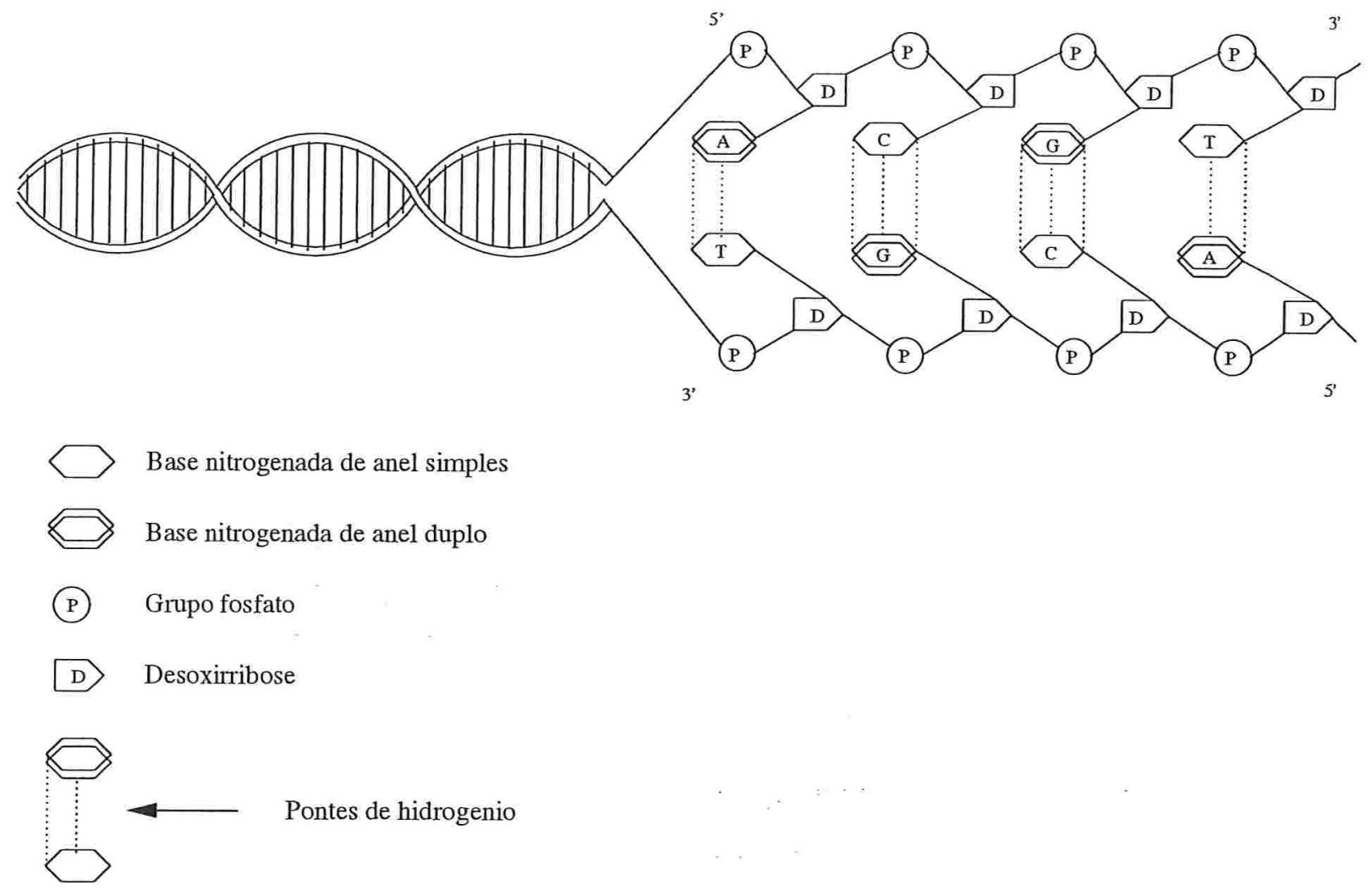

Figura 2.1: Molécula de DNA

O RNA é também uma longa fita de nucleotídeos ligados entre si. Contrariamente ao DNA, porém, a molécula de RNA é sempre constituída por uma fita única.

Há três tipos de RNAs que exercem diferentes funções:

- RNA mensageiro (mRNA): exerce o papel de cópia das informações do DNA;

- RNA transportador (tRNA): responsável pelo transporte de aminoácidos até o local de síntese proteica;

- RNA ribossômico (rRNA): possui um papel estrutural, formando os ribossomos.

O fato da molécula de RNA ser formada por uma fita única permite que bases complementares, em certos trechos dessa fita, se liguem. Isso causa dobras na molécula, concedendo a ela uma estrutura tridimensional. Essa estrutura é conhecida como estrutura secundária. 


\subsubsection{A síntese de proteínas}

Assim como o DNA, proteínas são também macromoléculas, formadas por moléculas menores, chamadas aminoácidos. Há vinte tipos de aminoácidos diferentes, e é a seqüência dessas moléculas que define cada tipo de proteína. Essa seqüência é codificada a partir da sequiência do DNA, onde cada aminoácido é codificado por uma região de três nucleotídeos, denominada códon. Isso faz com que o DNA seja visto como um molde para a síntese de proteínas.

\subsubsection{Similaridades entre seqüências}

A importância de encontrar similaridades entre seqüências vem da estreita relação entre estrutura e função. Trechos de DNA com seqüências semelhantes possuem geralmente funcionalidades semelhantes. Utilizando essa noção, são procuradas em bases de dados seqüências similares a de um gene cuja função seja conhecida. A busca dessas similaridades é uma estratégia utilizada, por exemplo, na caracterização de genes de parasitas que sejam vitais a ele $\left[B L B^{+} 01\right]$. Essa caracterização pode fornecer informações importantes para a pesquisa de drogas de combate a esse parasita.

Seqüências similares podem ser agrupadas em famílias, das quais pode ser extraído algum modelo que as caracterize. Esse modelo permite a busca de outras seqüências similares armazenadas em bases de dados, proporcionando uma checagem cruzada entre suas anotações [TO00].

\subsubsection{Mutações}

Em um processo evolutivo as moléculas de DNA e RNA sofrem um processo de mutações. Essas mutações genéticas são causadas por quebras e rearranjos das seqüências de nucleotídeos.

Alguns exemplos de mutação podem ser vistos na figura 2.2, onde são mostradas uma mutação pontual (afetando um único nucleotídeo), uma mutação causada por deleção e uma mutação causada por inversão de uma seqüência $\left[\mathrm{ABL}^{+} 94 \mathrm{a}\right]$.

Uma mutação na seqüência de um gene pode levar à sintese de uma proteína diferente da que seria sintetizada pela seqüência original ${ }^{3}$. Essa proteína mutante, por sua vez, pode

\footnotetext{
${ }^{3}$ Uma mutação pontual, por exemplo, pode não implicar na síntese de uma proteína mutante. Alguns
} 


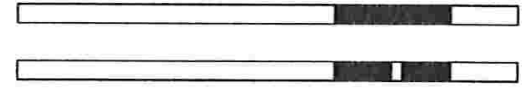

Pontual

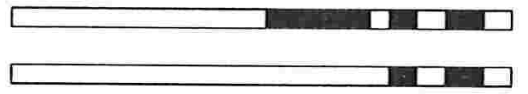

Deleçao

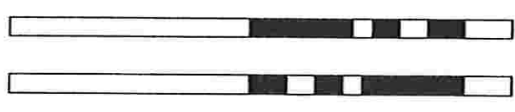

Inversao

Figura 2.2: Alguns tipos de mutações

desempenhar uma função diferenciada em relação à da proteína que seria produzida normalmente ${ }^{4}$. Essas mutações podem ser a causa de doenças ou de resistência a drogas em organismos patógenos $\left[\mathrm{CFS}^{+} 02\right]$.

Mutações podem ocorrer de forma aleatória ${ }^{5}$. O processo de mutações pode ser modelado através de um processo estocástico. Na seção 2.4 é apresentado como é possível aplicar essa abordagem na modelagem de seqüências genômicas.

\subsection{Aprendizado computacional}

O problema de caracterizar famílias de seqüências a partir de conjuntos de exemplos pode ser visto como um problema de aprendizado computacional. Nesta seção é apresentada a definição matemática de aprendizado e como essa abordagem pode ser aplicada na construção de um classificador de seqüências.

aminoácidos podem ser produzidos a partir de códons diferentes, chamados códons sinônimos. Assim, se a mutação ocorreu em um nucleotídeo de forma a produzir um códon sinônimo, não haverá mutação na seqüência da proteína.

${ }^{4}$ Uma alteração na seqüência de uma proteína pode não interferir em sua função. Isto ocorre porque não é simplesmente a seqüência de uma proteína que determina sua funcionalidade, mas principalmente seu formato tridimensional.

${ }^{5}$ Apesar da ocorrência de mutações poder ser aleatória, estas podem ser propagadas ou não. Dizemos que uma mutação ocorrida em um organismo foi propagada se esta ocorrer nos descendentes desse organismo. Um dos motivos de não propagação é por se tratar de uma mutação prejudicial ao organismo que a possui a ponto deste organismo ser eliminado de sua população por um processo de seleção natural [ABL $\left.{ }^{+} 94 \mathrm{~b}\right]$. 
Valiant [Val84] define aprendizado como sendo o fenômeno de aquisição de conhecimento na ausência de programação explícita. Na tentativa de inspecionar esse fenômeno, buscando metodologias que possam ser aplicadas no treinamento de computadores para tomada de decisões, nasceu a área de pesquisa conhecida como aprendizado computacional[AB92] [Tom96].

O alvo de um processo de aprendizado é um conceito. Um conceito é um predicado capaz de dizer se um dado é verdadeiro ou falso [Val84]. Por exemplo, um conceito de gene de câncer é capaz de, dada um gene, reponder se ele é de câncer ou não.

A seguir serão apresentadas algumas definições formais que ajudam a modelar um processo de aprendizado. Estas definições foram extraídas de [AB92] [Tom96].

Modelagem matemática de aprendizado Seja $\Sigma$ um conjunto de elementos usados para descrever exemplos, chamado de alfabeto de descriçẫo. Representa-se como $\Sigma^{*}$ o conjunto de todas as cadeias de tamanho finito formadas a partir da concatenação de elementos de $\Sigma$.

Definição 1 : Um exemplo x é um elemento de $\Sigma^{*}$ que pode ou não representar o conceito que se quer aprender ${ }^{6}$. O conjunto de todos os exemplos é chamado de espaço de exemplos e denotado por $X$.

Definição 2 : Um exemplo é dito ser um exemplo positivo se ele representa o conceito. Caso contrário, ele é dito ser um exemplo negativo.

Definição 3 : Um conceito $c$ é uma função $c: X \mapsto\{0,1\}$, ou seja, é uma função que, dado um exemplo $x \in X$, determina se o exemplo é verdadeiro $(c(x)=1)$ ou não $(c(x)=0)$ em relação ao conceito $c$. O conjunto de conceitos a serem aprendidos é chamado de espaço de conceitos $\mathrm{C}$

Definição 4 : Uma hipótese de um conceito c é uma função $h: X \mapsto\{0,1\}$ que aproxima c. O conjunto de possíveis hipóteses é chamado de espaço de hipóteses $H$.

Definição 5 : Uma amostra é um subconjunto de X. O tamanho de uma amostra é dado pelo número de exemplos que ela possui.

\footnotetext{
${ }^{6} \mathrm{O}$ termo conceito será logo definido formalmente, bastando no momento pensá-lo como sendo "o que" se quer aprender.
} 
Definição 6 : Uma amostra s é dita ser uma amostra de treinamento quando cada exemplo $x_{i}$ de s está rotulado por $b_{i}$, informando se $x_{i}$ é um exemplo positivo $\left(b_{i}=1\right)$ ou negativo $\left(b_{i}=0\right)$. Assim, uma amostra de treinamento de tamanho $m$ seria da forma:

$$
s=\left(\left(x_{1}, b_{1}\right),\left(x_{2}, b_{2}\right),\left(x_{3}, b_{3}\right), \ldots,\left(x_{m}, b_{m}\right)\right) .
$$

Definição 7 : $O$ conjunto $S_{X}$ é o conjunto de todas as amostras de treinamento $s$ sobre o conjunto de exemplos $X$.

Definição 8 : Um algoritmo de aprendizado $L$ para um espaço de conceitos $C$ e um espaço de hipóteses $H$ é uma função $L: S_{X} \rightarrow H$ que, dada uma amostra de treinamento $s \in S_{X}$ de um conceito $c \in C$, constrói uma hipótese $h \in H$ que seja uma aproximação de $c$.

\subsection{Noções preliminares de linguagens formais}

Nesta seção serão apresentados alguns conceitos da teoria de linguagens formais que serão utilizados neste trabalho. Esses conceitos foram extraídos de [AU72, Sal73, HU79], onde é apresentada a teoria de linguagens formais.

Para definir uma linguagem é preciso um alfabeto. Um alfabeto $\Sigma$ é qualquer conjunto finito de símbolos que podem ser, por exemplo, letras ou dígitos. Uma cadeia é uma seqüência de símbolos do alfabeto concatenados. A cadeia vazia, denotada $\varepsilon$, é uma cadeia com número de símbolos igual a zero.

Definição 1 : Uma linguagem sobre um alfabeto $\Sigma$ é um conjunto de cadeias sobre $\Sigma$.

Definição 2 : Uma gramática é uma quádrupla $G=\left(V_{n}, V_{t}, S, P\right)$ onde:

- $V_{n}$ é um conjunto finito de símbolos não terminais;

- $V_{t}$ é um conjunto finito de símbolos terminais;

- $S \in V_{n}$ é o símbolo inicial;

- $P \subset\{\alpha \rightarrow \beta\}$, onde $\alpha \in\left(V_{n} \cup V_{t}\right)^{*} V_{n}\left(V_{n} \cup V_{t}\right)^{*} \quad e \quad \beta \in\left(V_{n} \cup V_{t}\right)^{*}$, é um conjunto finito de produções. 
Uma gramática descreve uma linguagem onde:

- o conjunto de símbolos terminais de uma gramática corresponde ao alfabeto da linguagem a ser descrita;

- as regras sintáticas são descritas em forma de produções;

- os símbolos não terminais são símbolos que auxiliam a elaboração de regras sintáticas.

Exemplo: a gramática $G=\left(V_{n}, V_{t}, S, P\right)$, onde:

- $V_{n}=\{\mathrm{A}, \mathrm{B}\}$

- $V_{t}=\{\mathrm{a}, \mathrm{u}\}$

- $S=\mathrm{A}$

- $P=\{\mathrm{A} \rightarrow \mathrm{aA}, \mathrm{A} \rightarrow \mathrm{B}, \mathrm{B} \rightarrow \mathrm{uB}, \mathrm{B} \rightarrow \mathrm{u}\}$

gera a linguagem composta pelas cadeias formadas por um número arbitrário de símbolos a seguidos de um número arbitrário de símbolos u $\left(a^{n} u^{m}\right), n, m \geq 1$

Definição 3 : Notação BNF é um padrão formal para descrever produções, onde:

- símbolos não terminais são descritos entre os símbolos $\langle e\rangle$;

- | equivale a "ou";

- $:=$ equivale a "é definido por".

As produções descritas no exemplo anterior, são descritas na notação BNF como ${ }^{7}$ :

$\langle\mathrm{A}\rangle::=\mathrm{a}\langle\mathrm{A}\rangle \mid\langle\mathrm{B}\rangle$

$\langle\mathrm{B}\rangle::=\mathrm{u}\langle\mathrm{B}\rangle \mid \mathrm{u}$

\footnotetext{
${ }^{7}$ Apesar do arcabouço tratar gramáticas em formato BNF, utilizaremos neste texto, com o intuito de facilitar a leitura, uma notação onde os símbolos terminais são descritos por letras minúsculas, os símbolos não terminais por letras maiúsculas, e as produções contêm o símbolo $\rightarrow$ para separar o lado esquerdo e o lado direito.
} 
Em 1959 Chomsky classificou as gramáticas em quatro categorias baseadas no formato de suas produções [Cho59]. Essas categorias estão ordenadas em ordem crescente de generalidade e complexidade de reconhecimento.

Definição $4: G$ é uma gramática regular (GR) se suas produções são de uma das duas formas abaixo:

- $A \rightarrow b, \quad A \in V_{n}, b \in V_{t}$

- $A \rightarrow b C, \quad A \in V_{n}, b \in V_{t}, C \in V_{n}$

Definição 5 : G é uma gramática livre de contexto (GLC) se suas produções são da forma:

$$
A \rightarrow \beta, \quad A \in V_{n}, \quad \beta \in\left(V_{t} \cup V_{n}\right)^{*}
$$

Definição 6 : G é uma gramática sensível ao contexto (GSC) se suas produções são da forma:

$$
\begin{gathered}
\alpha \rightarrow \beta, \quad \alpha \in\left(V_{t} \cup V_{n}\right)^{*} V_{n}\left(V_{t} \cup V_{n}\right)^{*}, \quad \beta \in\left(V_{t} \cup V_{n}\right)^{*}, \quad|\alpha| \leq|\beta|, \text { onde }|T| \text { denota } o \\
\text { número de símbolos da cadeia } T \text {. }
\end{gathered}
$$

Definição 7 : G é uma gramática irrestrita (GI) se suas produções são da forma:

$$
\alpha \rightarrow \beta, \quad \alpha \in\left(V_{t} \cup V_{n}\right)^{*} V_{n}\left(V_{t} \cup V_{n}\right)^{*}, \quad \beta \in\left(V_{t} \cup V_{n}\right)^{*}, \quad \alpha \neq \varepsilon
$$

Definição 8 : Dadas duas cadeias $c_{1}$ e $c_{2}$, $c_{2}$ é uma derivação direta de $c_{1}$, denotada por $c_{1} \Rightarrow c_{2}$ se existem quatro cadeias $f_{1}, f_{2}, \alpha$ e $\beta$ (vazias ou não), tais que:

- $c_{1}=f_{1} \alpha f_{2}$

- $c_{2}=f_{1} \beta f_{2}$

- $\alpha \rightarrow \beta \in P$ 
Definição 9 : Uma cadeia $c_{2}$ é uma derivação de uma cadeia $c_{1}$, denotada por $c_{1} \stackrel{*}{\Rightarrow} c_{2}$ se existem cadeias $c_{11}, c_{12}, \ldots, c_{1 n}$, onde $c_{1} \Rightarrow c_{11} \Rightarrow c_{12} \Rightarrow \ldots \Rightarrow c_{1 n}=c_{2}$.

Definição 10 : Uma cadeia $c_{1}$ é uma sentença de uma gramática $G=\left(V_{n}, V_{t}, S, P\right)$ se

$$
c_{1} \in\left\{c \in V_{t}^{*} \mid S \stackrel{*}{\Rightarrow} c\right\}
$$

Ou seja, uma sentença é uma cadeia composta apenas de símbolos terminais que seja derivação do símbolo inicial.

Definição 11 : Dada uma gramática $G$, a linguagem gerada por $G$, denotada por $L(G)$, é o conjunto de todas as sentenças de $G$.

Definição 12 : Duas gramáticas são equivalentes se elas geram a mesma linguagem.

O processo de derivação de uma cadeia segundo uma gramática pode ser descrito graficamente em forma de uma árvore. Esta árvore é chamada árvore sintática ou árvore de derivação.

Definição 13 : Dada uma gramática $G=\left(V_{n}, V_{t}, S, P\right)$ livre de contexto e uma cadeia $c$ da linguagem gerada por $G$, uma árvore é uma árvore sintática ou árvore de derivação segundo $G$ se:

- cada nó possui um rótulo, que é um símbolo do conjunto $\left(V_{t} \cup V_{n}\right)$;

- o rótulo do nó raiz é $S$;

- se o nó $n$ tem rótulo $A$ e os nós $n_{1}, n_{2}, \ldots, n_{k}$ são filhos do nó $n$, na ordem da esquerda para a direita, com rótulos $X_{1}, X_{2}, \ldots, X_{k}$, respectivamente, então $A \in V_{n} e$

$$
A \rightarrow X_{1} X_{2} \ldots X_{k}
$$

é uma produção de P; 
Para exemplificar uma árvore de derivação, considere a gramática abaixo.

$G_{\text {branch }}$ :

$\mathrm{S} \quad \rightarrow \quad \mathrm{SS}|\mathrm{aSu}| \mathrm{uSa}|\mathrm{cSg}| \mathrm{gSc}$

| au $|\mathrm{ua}| \mathrm{cg} \mid \mathrm{gc}$

A cadeia agcuagcu é uma cadeia aceita por essa gramática, onde uma possível derivação é:

$\mathrm{S} \rightarrow \mathrm{SS} \rightarrow \mathrm{aSuS} \rightarrow$ agcuS $\rightarrow$ agcuaSu $\rightarrow$ agcuagcu

Construindo cada nível da árvore segundo cada derivação direta, partindo do símbolo inicial como raiz, produz-se a árvore de derivação para a cadeia agcuagcu mostrada na figura $^{8} 2.3$.

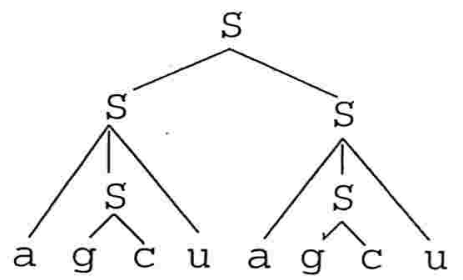

Figura 2.3: Árvore sintática da cadeia acguacgu

Definição 14 : Uma gramática $G$ é ambígua se existe uma cadeia $c \in L(G)$ que possui duas árvores sintáticas distintas.

A gramática $G_{b r a n c h}$ é ambígüa, pois a cadeia agcuagcu possui uma segunda derivação, cuja árvore sintática é mostrada na figura 2.4.

Derivação 2:

$$
\mathrm{S} \rightarrow \mathrm{aSu} \rightarrow \text { agScu } \rightarrow \text { agcSgcu } \rightarrow \text { agcuagcu }
$$

\footnotetext{
${ }^{8}$ Foram omitidos os símbolo $<>$ dos não terminais para não sobrecarregar a figura.
} 


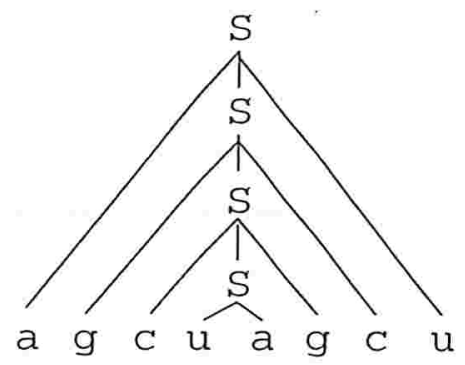

Figura 2.4: Segunda árvore sintática da cadeia acguacgu

Definição 15 : Uma gramática estocástica é uma quádrupla $G_{s}=\left\{V_{n}, V_{t}, P_{s}, S\right\}$ onde:

- $V_{n}, V_{t}, S$, possuem o mesmo significado que em gramáticas não estocásticas,

- $P \subset\{\alpha \rightarrow \beta, \quad p\}$, onde $\alpha \in\left(V_{n} \cup V_{t}\right)^{*} V_{n}\left(V_{n} \cup V_{t}\right)^{*} \quad e \quad \beta \in\left(V_{n} \cup V_{t}\right)^{*}$, é o conjunto de produções. A cada produção está associada uma probablidade $p, 0 \leq p \leq 1$.

- para cada $\alpha \in\left(V_{t} \cup V_{n}\right)^{*} V_{n}\left(V_{t} \cup V_{n}\right)^{*}$, considerando as produções $\left\{\alpha \rightarrow \beta_{i}, \quad p_{i}\right\} \in$ $P_{s}, \quad \beta_{i} \in\left(V_{n} \cup V_{t}\right)^{*}$, temos que $\sum_{i} p_{i}=1$

Definição 16 : Um analisador sintático para uma gramática $G$ é um programa que, dada uma cadeia $c$, fornece uma árvore sintática ${ }^{9}$ de $c$, se c for uma sentença de $G$, ou uma mensagem de erro indicando que c não é uma sentença de $G$ no caso contrário.

Definição 17 : Um analisador sintático para uma gramática estocástica $G_{s}$ é um analisador sintático que dada uma cadeia c, se esta for uma sentença de $G$, além de fornecer uma árvore sintática de $c$, fornece a probabilidade ${ }^{10}$ de $c$ segundo a gramática $G_{s}$. Caso contrário, fornece uma mensagem de erro indicando que c não é uma sentença de $G$.

\subsection{Aplicações em bioseqüências}

Como apresentado na seção 2.1, uma molécula de DNA ou RNA é composta por uma seqüência de nucleotídeos: adenina (a), guanina (g), citosina (c) e, timina ( $\mathrm{t}$ ) no DNA

\footnotetext{
${ }^{9}$ Se a gramática for ambígüa, a cadeia $c$ pode ter mais de uma árvore de derivação. Neste caso, o analisador sintático pode fornecer todas ou uma delas, dependendo de seu algoritmo.

${ }^{10}$ No caso de um analisador sintático que forneça todas as árvores sintáticas de uma cadeia, a probabilidade da cadeia é a soma das probabilidades de cada árvore sintática.
} 
ou uracila (u) no RNA. Representar as moléculas de DNA e RNA através de cadeias formadas por essas letras permite a formalização de seqüências biológicas utilizando a teoria de linguagens formais.

Nessa abordagem, a linguagem do DNA e do RNA é formada por um conjunto de cadeias cujo alfabeto é composto pelos símbolos a,g, c,t e a,g, c, u, respectivamente. Foi visto que linguagens podem ser descritas por gramáticas, e que há diferentes classes gramaticais que modelam diferentes classes de linguagens. Duas perguntas a serem feitas então seriam: qual classe gramatical é capaz de descrever toda a linguagem do DNA e do RNA? Que estruturas genéticas podem ser modeladas com cada tipo de gramática? A pertinência dessas questões neste trabalho deve-se ao objetivo de desenvolvimento de um arcabouço geral o suficiente para permitir o uso de vários tipos de gramáticas que possam modelar o DNA e o RNA.

\subsubsection{Gramáticas estocásticas podem ser utilizadas}

Em uma família de seqüências de DNA ou RNA, algumas estruturas são mais características que outras. Isso define uma distribuição probabilística das sequiências sobre a linguagem genômica. Essa linguagem não é conhecida, nem tampouco a distribuição das seqüências sobre ela. Para modelar uma família de seqüências, pretende-se realizar uma generalização de conjuntos incompletos de exemplos. Acreditando que esses conjuntos, as amostras, possuem uma distribuição semelhante da linguagem desconhecida, essa distribuição será utilizada para modelar as estruturas mais características. Com a utilização de gramáticas estocásticas, é possível estimar uma distribuição de probabilidades sobre as produções, associando probabilidades a elas.

Essa noção pode ser aplicada na modelagem de qualquer estrutura biólogica. Um exemplo é a modelagem de estruturas secundárias de RNA. Será mostrado ainda neste capítulo que a gramática que descreve essas estruturas pode ser ambígua, pois aparentemente poderiam ocorrer vários dobramentos de uma mesma molécula de RNA, porém alguns são mais prováveis que outros. Gramáticas livres de contexto estocásticas podem modelar essa distribuição de estruturas.

Outro fenômeno que poderia ser descrito por gramáticas estocásticas são as mutações. O processo de mutação genética, onde as mutações são causadas por quebras e rearranjos aleatórios de pedaços do genoma, pode ser visto como um processo estocástico. É possível inserir em uma gramática algumas produções associadas a baixas probabilidades, conheci- 
das como produções de erro, que modelam uma inserção, deleção ou substituição de um nucleotídeo. Desta maneira, acredita-se que gramáticas estocásticas apresentem um modelo melhor que os apresentados por gramáticas não-estocásticas para caracterizar a estrutura do genoma.

\subsubsection{Gramáticas regulares podem ser utilizadas}

A classe de gramáticas regulares é a classe gramatical mais limitada, ocupando a base da hierarquia de Chomsky [Cho59]. As linguagens que podem ser modeladas por esse tipo de gramática são aquelas que podem ser descritas por expressões regulares.

O DNA e o RNA são cadeias lineares de nucleotídeos. Dessa forma, é possível escrever uma gramática regular que modele sua seqüência. A aplicação de gramáticas regulares estocásticas na modelagem de seqüências biológicas está sendo estudada por Daniel Vieira [Vie02]. Um das aplicações poderia ser a caracterização de fronteiras entre éxons e íntrons ${ }^{11}$.

Gramáticas regulares estocásticas podem ser vistas como cadeias de Markov ocultas [BB01]. Estas também têm sido aplicadas em problemas biológicos como, por exemplo, de identificação de genes [Fic96, HSF97].

\subsubsection{A linguagem do DNA e do RNA é no mínimo livre de contexto}

DNAs e RNAs podem ser modelados com gramáticas regulares. Porém, essa modelagem fornece uma visão simplista dessas moléculas como sendo lineares e unidimensionais. Algumas moléculas, como RNAs, apresentam estrutura secundária. Essa estrutura está relacionada com o papel biológico que desempenham [Sea92].

A estrutura secundária de um RNA confere a ele uma característica bidimensional. Os dobramentos dessa molécula são caracterizados por dependências entre bases pareadas. Essas dependências possuem distâncias arbitrárias, o que não pode ser descrito por gramáticas regulares. Porém, a maioria dessas estruturas podem descritas por GLCs. Além dessa capacidade de modelagem, a árvore de derivação de uma cadeia de RNA segundo uma GLC pode descrever a estrutura secundária dessa cadeia.

$$
G_{\text {hairpin: }}
$$

$\mathrm{S} \rightarrow \mathrm{aSu}|\mathrm{uSa}| \mathrm{cSg} \mid \mathrm{gSc}$

\footnotetext{
${ }^{11}$ Éxons e íntrons são, respectivamente, regiões codificantes e não codificantes de genes.
} 


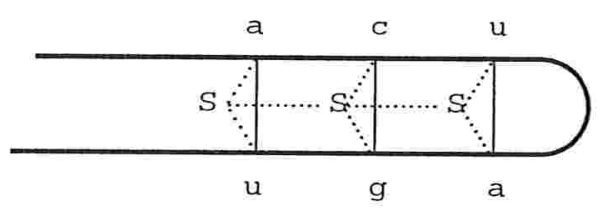

Figura 2.5: Estrutura hairpin descrita por $G_{\text {hairpin }}$

| au | ua $|\mathrm{cg}| \mathrm{gc}$

A estrutura hairpin, mostrada na figura 2.5, é formada a partir de uma dobra simples do RNA causada pela ligação de suas bases complementares. A gramática $G_{\text {hairpin }}$ é um exemplo de GLC que modela essa estrutura. A ligação entre as bases complementares é descrita pelas dependências entre os terminais de cada produção. Assim, quando uma produção é da forma "S $\rightarrow$ aSu", impõe-se a dependência entre a e u. O restante da seqüência entre essas bases deve ser gerado por uma nova aplicação do não terminal $S$, e assim sucessivamente até que $\mathrm{S}$ seja substituído por cadeia contendo apenas terminais.

Laços também podem ser descritos por GLCs. A estrutura da figura 2.6 é conhecida como stem-loop (caule e laço). O caule seria um trecho de bases ligadas, como na estrutura hairpin, e o laço um trecho de bases não pareadas, formando assim um bolsão de bases "soltas". Essas bases não pareadas são descritas, na gramática $G_{\text {stem-loop }}$, pelas produções em que aparece apenas um terminal e um não terminal no lado direito, como por exemplo "A $\rightarrow \mathrm{aA} "$.

$$
\begin{aligned}
& \text { Gstem-loop: } \\
& \mathrm{S} \rightarrow \quad \mathrm{aSu}|\mathrm{uSa}| \mathrm{cSg} \mid \mathrm{gSc} \\
& \\
& |\mathrm{A}| \mathrm{aAa}|\mathrm{aAc}| \mathrm{aAg}|\mathrm{cAa}| \mathrm{cAc}|\mathrm{cAu}| \mathrm{gAa} \\
& |\mathrm{gAg}| \mathrm{gAu}|\mathrm{uAu}| \mathrm{uAc} \mid \mathrm{uAg} \\
& |\mathrm{a}| \mathrm{g}|\mathrm{c}| \mathrm{u} \mid \\
& \mathrm{A} \rightarrow \quad \mathrm{aA}|\mathrm{cA}| \mathrm{gA}|\mathrm{uA}| \\
& |\mathrm{a}| \mathrm{g}|\mathrm{c}| \mathrm{u} \mid
\end{aligned}
$$




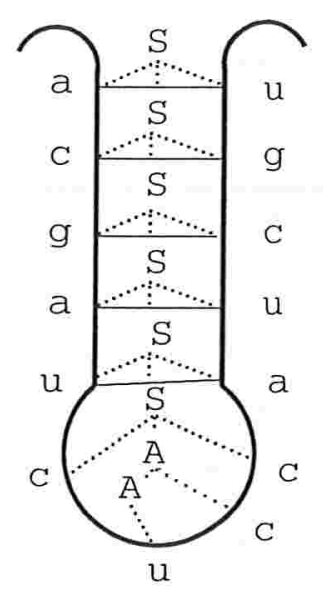

Figura 2.6: Estrutura de laço descrita por $G_{\text {stem-loop }}$

A figura 2.7 mostra ramificações na estrutura secundária do RNA. Essas estruturas são descritas na gramática $G_{\text {branch }}$ através da produção "S $\rightarrow$ SS".

\footnotetext{
$G_{\text {branch }}$ :

$\mathrm{S} \quad \rightarrow \quad \mathrm{SS}|\mathrm{aSu}| \mathrm{uSa}|\mathrm{cSg}| \mathrm{gSc} \mid$

| au | ua | cg $\mid \mathrm{gc}$
}

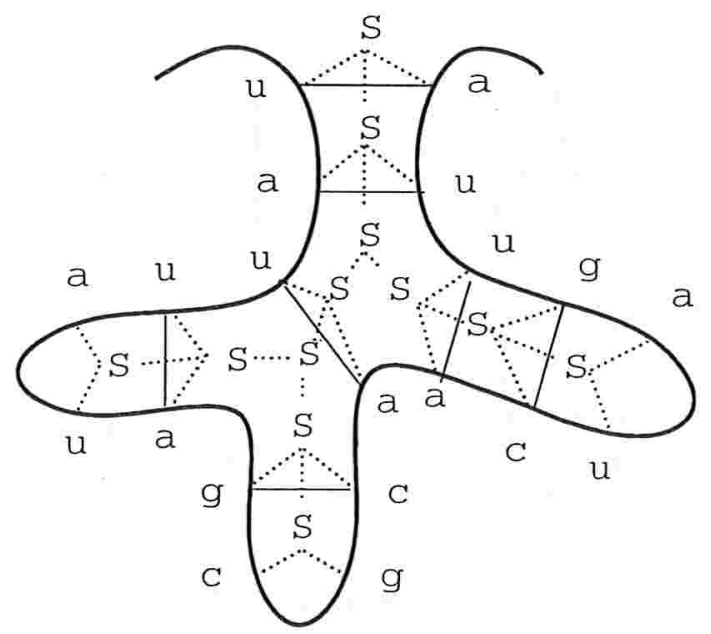

Figura 2.7: Estrutura de ramificação descrita por $G_{\text {branch }}$ 
Como ramificações são estruturas comuns em RNAs, a gramática $G_{\text {branch }}$ foi utilizada como uma das gramáticas dos testes descritos no capítulo 6.

Ambigüidade Cada RNA apresenta uma estrutura secundária específica. No entanto, observando apenas sua seqüência linear, é possível notar várias possibilidades de dobramentos diferentes. Essa característica pode ser descrita por gramáticas ambíguas, segundo as quais uma mesma cadeia pode apresentar diferentes derivações, mudando a ordem em que as produções são utilizadas. Veja o exemplo da gramática $G_{\text {branch }}$ e da cadeia agcuagcu que possui duas diferentes derivações, originando duas possíveis estruturas secundárias mostradas na figura 2.8:

Derivação 1:

$\mathrm{S} \rightarrow \mathrm{SS} \rightarrow \mathrm{aSuS} \rightarrow$ agcuS $\rightarrow$ agcuaSu $\rightarrow$ agcuagcu

Derivação 2:

$$
\mathrm{S} \rightarrow \mathrm{aSu} \rightarrow \text { agScu } \rightarrow \text { agcSgcu } \rightarrow \text { agcuagcu }
$$
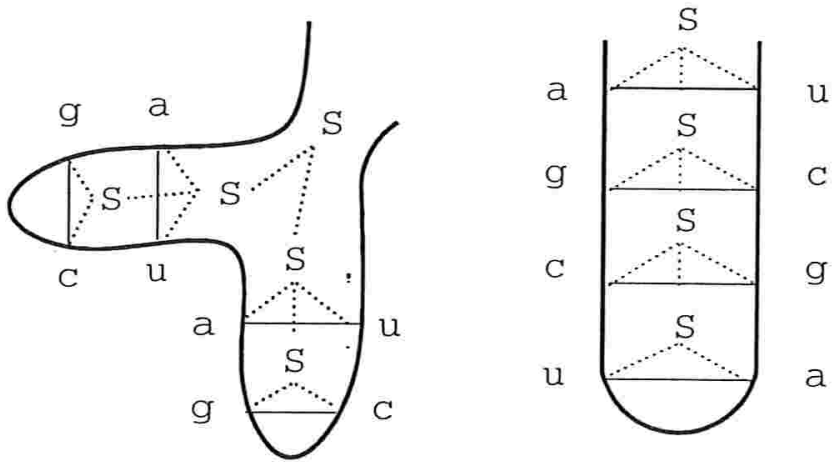

Figura 2.8: À esquerda a estrutura secundária segundo a derivação 1. À direita a a estrutura secundária segundo a derivação 2 . 


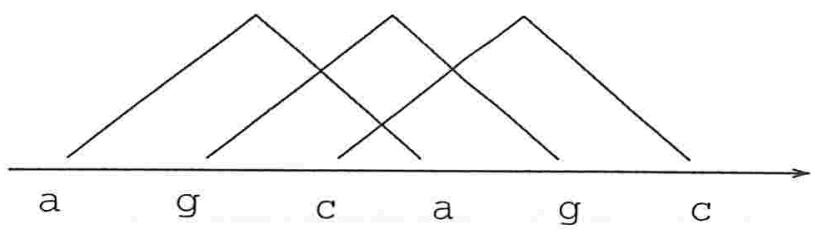

Figura 2.9: Dependências cruzadas de uma repetição

\subsubsection{A linguagem do DNA e do RNA é sensível ao contexto}

Searls [Sea92, SD93, Sea97, Sea99] apresenta ainda outras estruturas presentes na linguagem dos ácidos nucleicos, como pseudo-nós, que indicam que essa linguagem deva pertencer a uma classe ainda maior que a das GLCs.

Observando as figuras 2.9 a 2.11 notamos que as relações de dependência entre as bases das seqüências de uma repetição e de um pseudo-nó (quando "esticado") se cruzam, sendo por isso chamadas de dependências cruzadas [Sea97]. Dependências cruzadas não podem ser descritas por GLCs, e sim por gramáticas sensíveis ao contexto [Sea92].

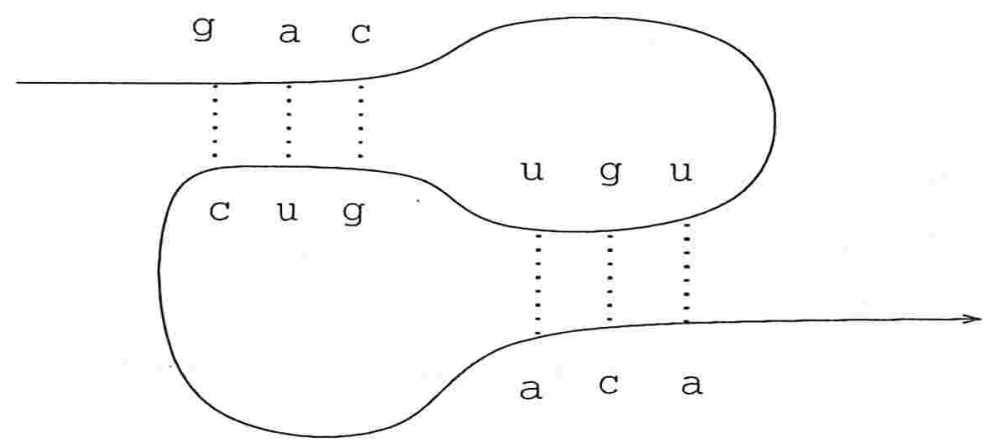

Figura 2.10: Estrutura de um pseudo-nó

Um problema, porém, que envolve as GSCs é que o problema de análise sintática de linguagens sensíveis ao contexto é NP-completo. Como essa classe de linguagens é muito complexa, Searls defende que a linguagem do DNA e do RNA pode pertencer a uma classe intermediária. Seus trabalhos têm se dirigido ao estudo de uma classe de gramáticas, chamada gramática de variáveis de strings [Sea93, SD93, Sea97]. Porém, na pesquisa realizada neste 


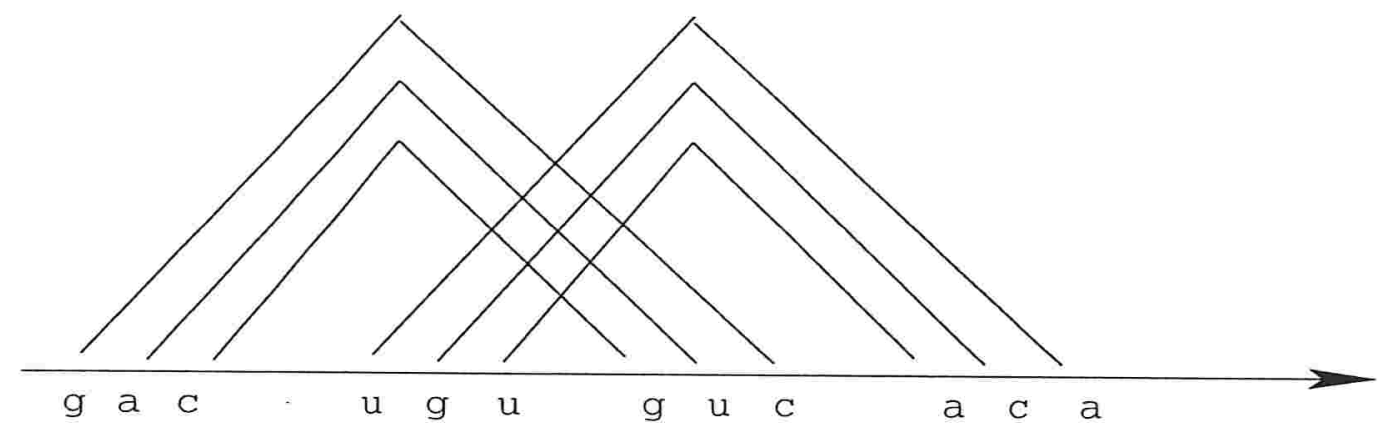

Figura 2.11: Dependências cruzadas de um pseudo-nó "esticado"

trabalho ${ }^{12}$, não foi encontrada nenhuma publicação sobre como inferir esse tipo de gramática a partir de seqüências de treinamento, que é o interesse deste trabalho.

\subsection{Classificação de Bayes}

O problema de classificação tratado neste trabalho pode ser representado através de um Classificador de Bayes [Fu82]. Um classificador bayesiano é um procedimento que recebe uma entrada $x$ e classifica-a segundo um conjunto de famílias $\omega_{j}, j=1, \ldots, n$. Para decidir a qual família $x$ deve pertencer, o classificador de Bayes utiliza curvas de distribuição de probabilidades, cada curva correspondente a uma família.

A entrada do classificador é modelada como uma variável aleatória $X$. Para cada família $\omega_{j}$, denota-se por $P\left(X \mid \omega_{j}\right)$ a função de distribuição de probabilidade de $X$ dada a família $\omega_{j}$, e por $P\left(\omega_{j}\right)$ a probabilidade de $\omega_{j}$ ocorrer. Assume-se que $P\left(X \mid \omega_{j}\right)$ e $P\left(\omega_{j}\right)$ são conhecidas. Para classificar uma entrada, o classificador bayesiano utiliza a regra de decisão de Bayes, que é:

$$
X \sim \omega_{i} \quad \text { se } P\left(\omega_{i}\right) P\left(X \mid \omega_{i}\right) \geq P\left(\omega_{j}\right) P\left(X \mid \omega_{j}\right) \quad \text { para todo } j=1, \ldots, n
$$

Ou seja, uma entrada $x$ é classificada como pertencente à família $\omega_{i}$ se, dentre todas as

\footnotetext{
${ }^{12} \mathrm{~A}$ pesquisa realizada neste trabalho foi baseada em buscas pela Internet e em referências bibliográficas de artigos sobre o tópico pesquisado.
} 
famílias, $\omega_{i}$ é a que apresenta a maior probabilidade de conter $x$.

Essa decisão é ilustrada na figura 2.12, que considera três famílias. Cada família fornece uma curva de probabilidade das seqüências. Cada seqüência será classificada segundo a curva que atinge sua maior probabilidade. Assim a seqüência $x_{i}$ é classificada como pertencente à família $\omega_{1}$ e a seqüência $x_{k}$ é classificada como pertencente à família $\omega_{2}$.

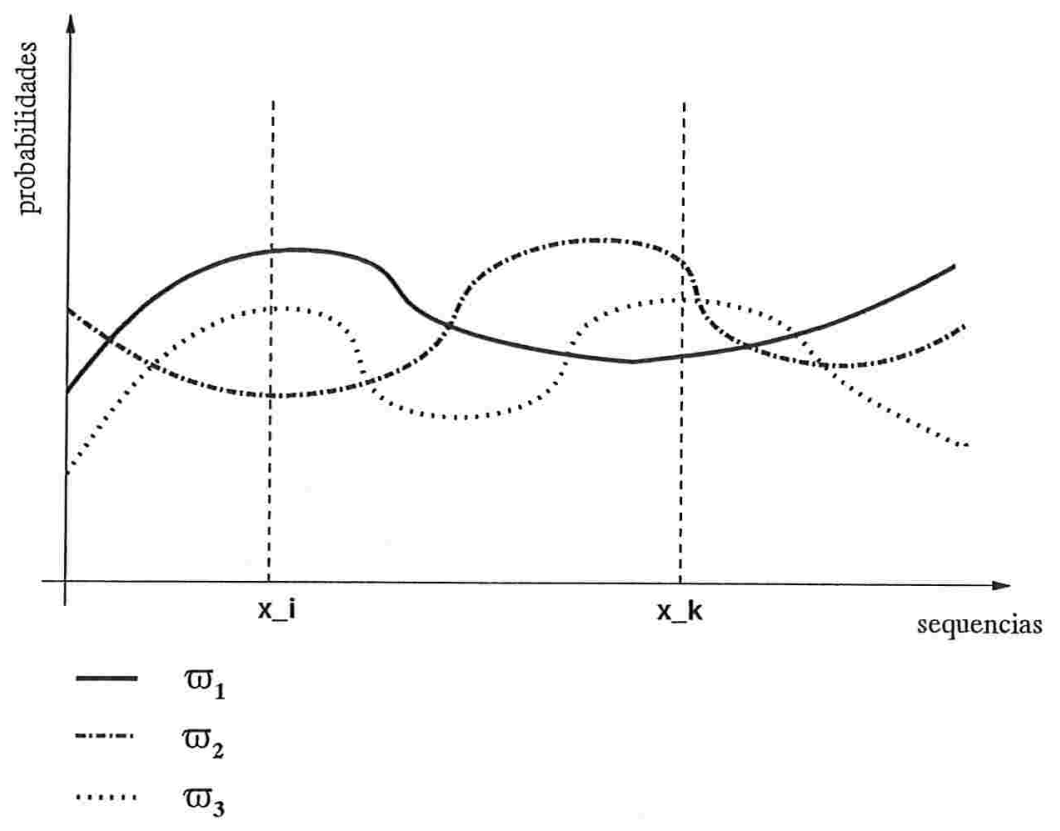

Figura 2.12: Curvas de probabilidade

\subsection{Aprendizado de classificadores}

O objetivo do sistema desenvolvido neste trabalho é gerar classificadores bayesianos pelos quais as famílias consideradas sejam representadas por gramáticas estocásticas. A construção desse classificador envolve uma fase de aprendizado das gramáticas estocáticas. Para isso serão utilizadas técnicas de inferência gramatical, que deduzem uma gramática a partir de um conjunto de exemplos. Para cada gramática aprendida será gerado um analisador sintático estocástico, como mostra a figura 2.13. Este analisador associará a cada sequência $x$ um valor de probabilidade $P\left(x \mid G_{i}\right)$, ou seja a probabilidade da seqüência $x$ ser gerada pela 
gramática $G_{i}$. Dessa forma, cada gramática estocástica pode ser vista como uma distribuição de probabilidades no domínio de seqüências. O classificador utiliza os valores fornecidos pelos analisadores para determinar qual a gramática que melhor representa uma seqüência $x$, utilizando a regra de decisão de Bayes.

\begin{tabular}{|c|c|c|c|c|}
\hline Amostra 1 & \multirow{3}{*}{$\begin{array}{c}\text { Aprendizado } \\
\text { gramatical }\end{array}$} & Analisador de Ge1 & & \multirow[b]{2}{*}{ Classificador } \\
\hline Amostra 2 & & Analisador de Ge2 & \multirow{2}{*}{$\begin{array}{c}\text { Gerador de } \\
\text { classificadores }\end{array}$} & \\
\hline $\begin{array}{l}\ldots \\
\text { Amostra n }\end{array}$ & & $\begin{array}{l}\ldots \\
\text { Analisador de Gen }\end{array}$ & & \\
\hline
\end{tabular}

Figura 2.13: Gerando classificadores

Em nosso contexto, porém, não temos informações para definir quais gramáticas são mais prováveis que as demais. Por isso consideraremos que as gramáticas são igualmente prováveis. Portanto, a regra de decisão pode ser simplificada para:

$$
X \sim G_{i} \text { se } P\left(X \mid G_{i}\right) \geq P\left(X \mid G_{j}\right) \quad \text { para todo } j=1, \ldots, n
$$

Ou seja seja, a seqüência x é classificada como sendo gerada pela gramática que maximiza a probabilidade $P\left(x \mid G_{i}\right)$. 


\section{Inferência gramatical}

No capítulo 2.2 foi visto que aprendizado computacional pode ser utilizado para gerar classificadores de seqüências a partir de exemplos de cada família. Foi visto também que essas famílias podem ser caracterizadas por gramáticas. Resta saber agora se essas gramáticas podem ser aprendidas, visando sua utilização na geração dos classificadores. A fim de tentar responder essa pergunta, este capítulo trata a teoria que estuda processos de aprendizado de gramáticas, conhecida como inferência gramatical.

Pode-se definir inferência gramatical como sendo um problema de aprendizado de linguagens formais a partir de exemplos de cadeias dessas linguagens, para o qual o espaço de hipóteses é uma família de gramáticas.

A seção 2.4.4 mostra que a linguagem do DNA e do RNA é sensível ao contexto. Porém não foram encontrados trabalhos publicados nesse assunto durante a pesquisa realizada neste trabalho. Mesmo que fosse implementado um algoritmo eficiente de inferência de GSCs, não seria possível implementar uma analisador sintático eficiente para a gramática inferida, pois a análise sintática de linguagens sensíveis ao contexto é um problema NP-completo [AU72].

Analisadores sintáticos de gramáticas livres de contexto são de ordem polinomial ${ }^{1}$. Gramáticas livres de contexto não são capazes de descrever todas as estruturas secundárias do genoma. Todavia, pode ser desejável modelar apenas parte dessa linguagem. Um objetivo pode ser, por exemplo, caracterizar diferentes famílias de RNAs. Como as GLCs impõem uma estrutura sintática sobre as seqüências, é possível utilizar essas estruturas para descrever estruturas secundárias desses RNAs e modelar o restante da seqüência sem a descrição das estruturas, apenas com dados estatísticos.

\footnotetext{
${ }^{1}$ Analisadores sintáticos de gramáticas regulares, além de polinomiais, são lineares.
} 
O objetivo deste trabalho é o desenvolvimento de um arcabouço genérico de geração de classificadores. Por esse motivo buscou-se considerar o problema de inferência da classe gramatical mais geral possível visando a caracterização das famílias de seqüências biológicas. Dessa maneira pretende-se viabilizar a utilização de classes gramaticais mais simples aproveitando a mesma estrutura do arcabouço. Por causa da inviabilidade do uso de analisadores sensíveis ao contexto e da característica estocástica do DNA e do RNA (seção 2.4.1), optamos por limitar essa pesquisa de inferência a gramáticas livres de contexto estocásticas.

Este capítulo apresenta brevemente alguns aspectos do problema de inferência gramatical. São eles: identificação no limite, métodos de busca e estratégias ${ }^{2}$ de inferência. Esses aspectos foram utilizados para limitar a escolha e implementação dos dois algoritmos de inferência a serem utilizados na avaliação preliminar da aplicação de GLCs na construção de classificadores de seqüências biológicas.

\subsection{Identificação no limite}

Dado um problema de inferência e um algoritmo a ser aplicado em sua resolução, um critério de parada define quando o algoritmo deve encerrar sua execução por ter encontrado a solução da inferência. Gold introduz em [Gol67] o critério de parada chamado identificação no limite.

O critério de parada de identificação no limite considera o processo de inferência como um processo potencialmente infinito. Assume a disponibilidade de um número infinito de exemplos de uma linguagem $L$ onde, a cada instante $t_{i}$, um exemplo é fornecido e uma gramática $g_{i}$ é inferida pelo algoritmo $M$. Estes exemplos podem ser todos positivos (apresentação positiva) ou conter também exemplos negativos (apresentação completa). O critério de parada do processo é quando, após um tempo $t_{k}$ finito, as gramáticas inferidas $g_{k}, g_{k+1}, g_{k+2}, \ldots$ são todas iguais a $g_{k}$. Neste caso, a linguagem $L$ é dita ser identificável no limite pelo algoritmo $M$.

Embora o critério de identificação no limite considere um processo infinito (e por isso impraticável), ele é muito utilizado para avaliações teóricas do sucesso e complexidade de métodos de inferência [Sak92, Sak97, Ang82, Yok91]. A noção de complexidade está rela-

\footnotetext{
${ }^{2}$ Os aspectos de critério de parada e métodos de busca aplicam-se a toda a área de inferência indutiva. Nesta seção consideramos apenas o problema de inferência gramatical.
} 
cionada com o tempo gasto pelo método na identificação de uma linguagem. Neste capítulo são citados alguns resultados baseados nesse critério.

\subsection{Métodos de busca}

Um método de busca pode ser entendido como sendo a forma utilizada para encontrar a gramática desejada dentro do espaço de busca. Sakakibara [Sak95] cita dois métodos de inferência gramatical: enumeração e construção.

- Método de enumeração:

Consiste em determinar uma enumeração do espaço de busca, ou seja, uma enumeração de gramáticas do domínio considerado. Após a construção de uma enumeração, iniciase a fase de análise da amostra de treinamento. A cada exemplo analisado da amostra, as gramáticas inconsistentes com o exemplo são eliminadas. Ao término da análise dos exemplos, todas as gramáticas restantes (caso exista mais que uma) são candidatas à resposta da inferência. Uma delas é escolhida segundo algum critério. Esse critério pode ser baseado, por exemplo, no número de produções, ou simplesmente na escolha aleatória de uma delas.

O grande problema desses algoritmos é a fase de enumeração do espaço de busca, que é tipicamente exponencial [AS83]. Por esse motivo, algoritmos que utilizam esse método não foram contemplados nesta pesquisa.

\section{- Método de construção:}

Esse método, ao invés de eliminar gramáticas inconsistentes de uma enumeração, constrói a gramática desejada com base nas cadeias da amostra. Normalmente, os algoritmos construtivos são polinomiais. Por esse motivo, a pesquisa de algoritmos a serem implementados neste trabalho centrou-se nesse método.

\subsection{Estratégias de inferência de GLCs}

Sakakibara mostra que a classe das gramáticas livres de contexto não pode ser identificada em tempo polinomial a partir simplesmente de uma apresentação positiva [Sak95]. Tornase necessário então, para inferir essas gramáticas, usar alguma estratégia que restrinja essa 
classe ou que não utilize apenas uma apresentação positiva. Serão apresentadas a seguir algumas estratégias apresentadas por Sakakibara [Sak95, Sak97] utilizadas nos processos de inferência de GLCs. Essas estratégias não são mutuamente exclusivas, podendo ser combinadas na implementação de um algoritmo.

\subsubsection{Auxílio de oráculos}

Angluin [Ang88] considerou um modelo de inferência, conhecido como query learning. Neste modelo, há a disponibilidade de um oráculo, uma entidade capaz de responder perguntas ao algoritmo de inferência. Essas perguntas normalmente são de dois tipos: de inclusão ou de equivalência.

No caso de perguntas de inclusão, é dada ao oráculo uma cadeia. Ele responde "sim" se ela for gerada pela gramática desconhecida, ou "não" caso contrário. Dessa forma obtém-se exemplos positivos e negativos.

No caso de perguntas de equivalência, é dada ao oráculo uma hipótese de gramática. Ele responde "sim" se ela for equivalente à gramática desconhecida. Caso contrário, ele responde "não" e fornece um contra-exemplo, ou seja, uma cadeia pertencente à diferença simétrica $^{3}$ entre a linguagem gerada pela gramática hipotética e a linguagem gerada pela gramática desconhecida.

Algoritmos que utilizam esta estratégia podem ser encontrados em [STSH00] e [Sak90]. No entanto, não há como assegurar a disponibilidade de um oráculo no meio biológico. Por esse motivo foi descartada a utilização neste trabalho de algoritmos que utilizam esta estratégia.

\subsubsection{Inferência a partir de exemplos estruturais}

Levi e Joshi [LJ78] desenvolveram uma forma de caracterizar sentenças através de suas descrições estruturais. No caso de gramáticas livres de contexto, essas descrições, chamadas esqueletos, seriam suas árvores de derivação sem a rotulação dos não terminais nos nós internos. Levy e Joshi sugerem que, ao agregar informações estruturais aos exemplos, há a possibilidade de desenvolvimento de algoritmos eficientes de inferência.

No caso de aplicações onde o uso de oráculos é viável, a combinação dessa estratégia com

\footnotetext{
${ }^{3} \mathrm{~A}$ diferença simétrica entre dois conjuntos $\mathrm{A}$ e $\mathrm{B}$ é definida por $(\mathrm{A} \cup \mathrm{B})-(\mathrm{A} \cap \mathrm{B})$
} 
o uso de exemplos estruturais traz um importante resultado. Sakakibara [Sak90] mostra que a classe de GLCs pode ser identificada em tempo polinomial utilizando perguntas estruturais de equivalência e de inclusão ${ }^{4}$. Serão apresentados adiante alguns outros resultados positivos envolvendo essa estratégia com e sem o uso de oráculos.

Considere a cadeia

\section{A carta do menino trouxe muitas informações relevantes}

Considerando a gramática da língua portuguesa, essa cadeia pode ser analisada segundo ítens sintáticos como sujeito, núcleo do sujeito, adjunto adnominal, predicado, objeto direto, etc. O esqueleto da árvore de derivação dessa cadeia não possui rótulos em seus nós interiores. A figura 3.1 mostra a representação gráfica desse esqueleto.

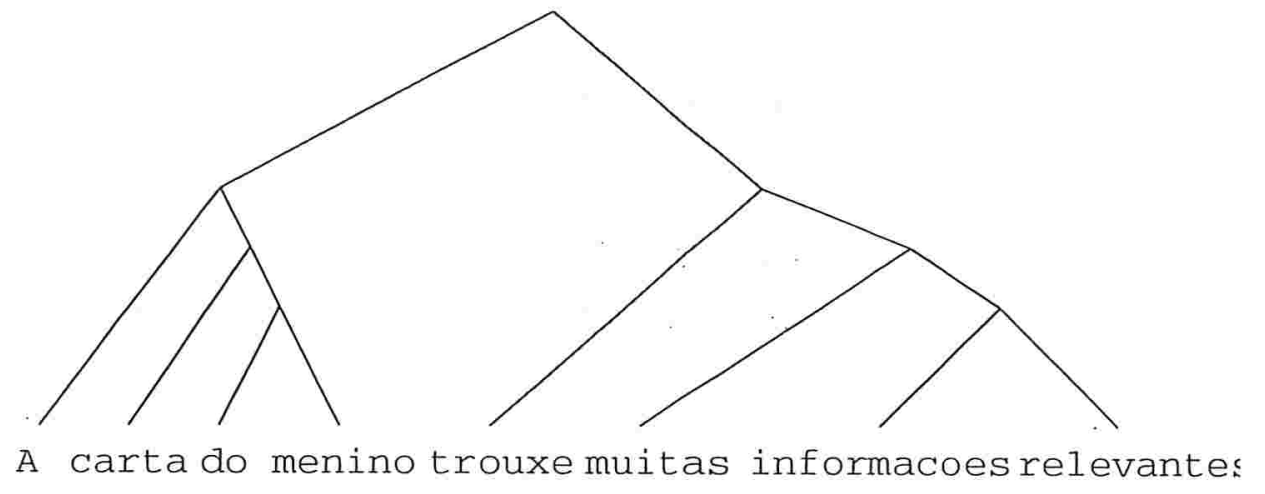

Figura 3.1: Esqueleto de uma frase

Um exemplo estrutural é uma cadeia com parêntesis de forma a indicar como seria seu esqueleto. $\mathrm{O}$ exemplo estrutural do esqueleto da figura 3.1 seria:

\section{$((A(\operatorname{carta}($ do menino))) (trouxe (muitas (informações relevantes))))}

Essa estratégia pode ser aplicada, por exemplo, quando a estrutura secundária das seqüências biológicas é conhecida.

Foram encontrados vários trabalhos que utilizam essa estratégia de apresentação de exemplos estruturais combinadas com outras estratégias [Mak92, Sak90, Sak92, SF00, SM00].

\footnotetext{
${ }^{4}$ Uma pergunta estrutural de inclusão é uma pergunta de inclusão de uma seqüência estruturada. Uma pergunta estrutural de equivalência retorna "sim" se uma gramática é estruturalmente equivalente à gramática desconhecida, e retorna "não" e um contra-exemplo caso-contrário.
} 


\subsubsection{Inferência de subclasses de GLCs}

Se for conhecido um pouco mais sobre o domínio da linguagem que se deseja caracterizar, é possível limitar o espaço de busca [Sak95]. Isso fornece a possibilidade de investigação de algoritmos mais eficientes de inferência de subclasses de GLCs. Foram pesquisadas algumas subclasses, mas a maioria delas restringe bastante o poder de expressão das gramáticas, comprometendo a descrição de muitos fenômenos biológicos.

Nesta sessão serão discutidas algumas dessas subclasses e suas restrições. Para facilitar a avaliação da capacidade de representação estrutural de cada subclasse, elas serão avaliadas quanto à possibilidade ou não de possuirem os tipos de produções descritas abaixo. Esses tipos de produções são suficientes para representar grande parte ${ }^{5}$ das estruturas secundárias de RNA[BB01].

1. Produções que representam pareamentos de bases complementares:

$$
S \rightarrow a S u \quad|u S a \quad| c S g \quad \mid g S c
$$

2. Produções que representam pareamentos de algumas bases não complementares, mas que ocorrem com uma certa freqüência:

$S \rightarrow g S u \quad \mid \quad g S a$

3. Produções que representam bases não pareadas, do lado esquerdo:

$$
S \rightarrow g S|u S| a S \mid c S
$$

4. Produções que representam bases não pareadas, do lado direito:

$$
S \rightarrow S g \quad|S u \quad| S a \quad \mid S c
$$

5. Produções que representam bases simples:

$$
S \rightarrow g|u| a \mid c
$$

6. Produções que representam ramificações:

$$
S \rightarrow S S
$$

\footnotetext{
${ }^{5}$ Não é possível representar estruturas de referência cruzada, como pseudo-nós, apenas com produções livres de contexto.
} 


\section{Gramáticas lineares}

Gramáticas livres de contexto lineares são GLCs que possuem no máximo um símbolo não terminal no lado direito das produções. Um algoritmo de inferência visando esse tipo de gramática é descrito em [SF00].

O problema desse tipo de gramática é que, apesar de descrever laços, não consegue descrever ramificações na estrutura secundária do RNA. Para descrever esse tipo de estrutura é necessário o uso de mais de um não terminal no lado direito. É o caso da ramificação vista na figura 3.2 representada pela produção de tipo $6, S \rightarrow S S$.

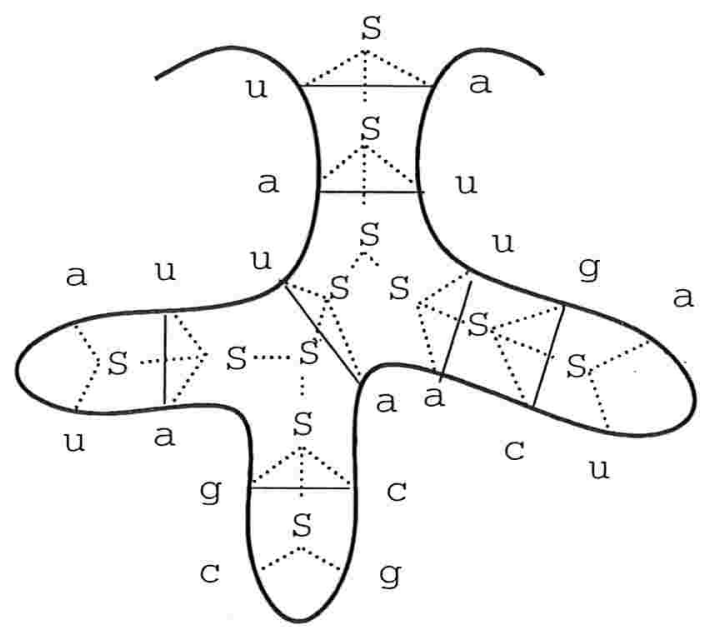

Figura 3.2: Ramificação em uma estrutura secundária de RNA

\section{Gramáticas lineares simétricas}

Gramáticas lineares simétricas possuem produções com mais restrições. As produções dessa classe de gramáticas devem ser da forma $A \rightarrow \alpha B \beta$ ou $A \rightarrow \gamma$, onde $A$ e $B$ são não terminals, $\alpha$, $\beta$ e $\gamma$ são seqüências de terminais, e $\alpha$ e $\beta$ possuem o mesmo tamanho ${ }^{6}$ [Tak88].

Um teorema em inferência gramatical afirma que o problema de identificação da classe de gramáticas lineares simétricas pode ser reduzido ao problema de identificação da classe de autômatos finitos [Tak88]. Gramáticas lineares simétricas, além de não permitir a repre-

\footnotetext{
${ }^{6} \mathrm{O}$ tamanho de uma seqüência é definido pelo número de símbolos que ela possui.
} 
sentação de ramificações, também não permitem a representação de laços como o da figura 3.3 , formados a partir de bases não pareadas?

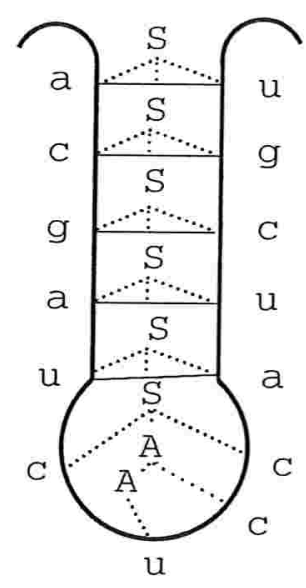

Figura 3.3: Laço em uma estrutura secundária de RNA

\section{Gramáticas reversíveis}

Uma gramática livre de contexto é reversível se e somente se $A \rightarrow \alpha$ e $B \rightarrow \alpha$ implicam que $A=B$, e $A \rightarrow \alpha B \beta$ e $A \rightarrow \alpha C \beta$ implicam que $B=C$ [Lee96]. Essas restrições não restringem o conjunto de linguagens geradas, permitindo que a classe de GLCs reversíveis gere toda a classe de linguagens livres de contexto [Sak95].

Sakakibara [Sak92] mostra que a classe de GLCs reversíveis pode ser identificada no limite a partir de uma apresentação positiva utilizando exemplos estruturais, propondo um algoritmo de inferência.

Devido à maior flexibilidade no formato das produções e ao poder de gerar todas as linguagens livres de contexto, essa classe de gramáticas foi escolhida como alvo de um dos algoritmos de inferência implementados neste trabalho para compor o gerador de classificadores. Este algoritmo é descrito na seção 3.4.1.

\footnotetext{
${ }^{7}$ Pode-se descrever alguns laços com produções cujo lado direito seja formado por todos os terminais da região não pareada. Porém o objetivo da modelagem aqui é representar regiões de laços de tamanhos arbitrários.
} 


\section{Gramáticas tipo-inversíveis}

Para definir gramáticas tipo-inversíveis são necessárias algumas definições preliminares:

- Seja uma função $h:\left(V_{n} \cup V_{t}\right)^{*} \rightarrow\{n, t\}^{*}$ onde:

Se $x \in\left(V_{n} \cup V_{t}\right)$,

$$
h(x)=n \text { se } x \in V_{n} \quad \text { e } \quad h(x)=t \text { se } x \in V_{t} .
$$

Se $x \in\left(V_{n} \cup V_{t}\right)^{*} \quad \mid \quad x=x_{1} x_{2} \ldots x_{k}, \mathrm{k}>1 \quad$ e $x_{i} \in\left(V_{n} \cup V_{t}\right), 1<i \leq \mathrm{k}$

$$
h(x)=h\left(x_{1}\right) h\left(x_{2}\right) \ldots h\left(x_{k}\right)
$$

isto é, a concatenação de $h\left(x_{1}\right), h\left(x_{2}\right) \ldots h\left(x_{k}\right)$

- Uma produção $A \rightarrow \alpha$ é terminal se e somente se $\alpha \in V_{t}^{*}$. Caso contrário a produção é dita ser não terminal.

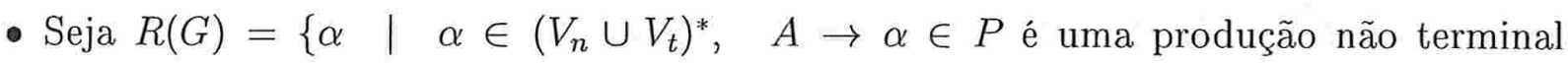
da gramática $G\}$. Uma gramática $G$ é $R$-separável se e somente se para cada $\alpha_{1}$ e $\alpha_{2} \in R(G)$ tal que $A \rightarrow \alpha_{1} \in P$ e $B \rightarrow \alpha_{2} \in P$, se $h\left(\alpha_{1}\right)=h\left(\alpha_{2}\right)$ então $A=B$. Ou seja, as produções que possuem o mesmo resultado da aplicação da função h em seu lado direito devem possuir o mesmo lado esquerdo.

- Um conjunto de produções $P$ é inversivel se $A \rightarrow \alpha \in P$ e $B \rightarrow \alpha \in P$, então $A=B$.

Uma gramática $G$ é dita tipo-inversível se ela for R-separável e se seu conjunto de produções terminais for inversível.

A classe de gramáticas tipo-inversíveis também é capaz de gerar toda a classe de linguagens livre de contexto. Mäkinen [Mak92] propõe um algoritmo de inferência para essa classe de gramáticas utilizando exemplos estruturais. Devido ao poder geração dessa classe de gramáticas esse algoritmo foi escolhido para implementação do segundo inferidor gramatical do gerador de classificadores (seção 3.4.2).

\subsection{Algoritmos implementados para o módulo de infer- ência}

Para fazer a escolha dos dois algoritmos a serem implementados, foram priorizados aqueles cuja aplicação fosse o mais geral possível em biologia molecular. Ou seja, foram considerados 
a classe de gramática inferida e a estratégia de inferência utilizada.

Em biologia molecular há informações sobre muitas seqüências, mas desconhecemos fontes de informações que possam fazer o papel de um oráculo. A utilização no processo de inferência das informações disponíveis pode ser pesquisada futuramente, mas no presente trabalho não foram pesquisados algoritmos que usam essa estratégia de oráculos.

Com relação às classes gramaticais inferidas, foram preferidas aquelas com menos restrições na estrutura, a fim do algoritmo poder ser aplicado a uma variedade maior possível de seqüências genéticas.

Baseados nesses fatores, foram implementados os algoritmos de inferência de gramáticas reversíveis [Sak92] e de gramáticas tipo-inversíveis [Mak92]. Estas classes gramaticais, como já visto, são capazes de gerar toda a classe de gramáticas livres de contexto.

\subsubsection{Algoritmo para inferência de gramáticas reversíveis}

Assim como toda gramática regular é equivalente a um autômato finito [HU79] há também uma estrutura, chamada autômato a árvore, à qual toda gramática livre de contexto é equivalente [LJ78]. Essa estrutura, mostrada na figura 3.4, consegue representar as árvores de derivação de seqüências reconhecidas por uma gramática livre de contexto. O algoritmo descrito em [Sak92] combina as estratégias de considerar uma subclasse de GLCs, GLCs reversíveis, e a de utilização de exemplos estruturais para inferir autômatos a árvore reversíveis. São definidas propriedades para caracterizar autômatos a árvore reversíveis, de forma que ele seja equivalente a uma gramática livre de contexto reversível.

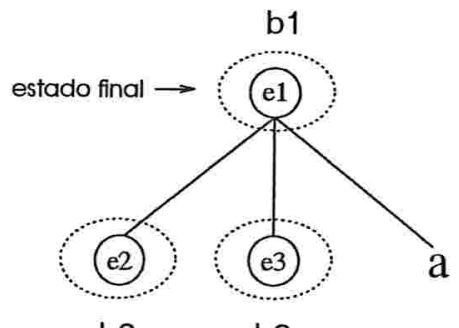

b2

b3

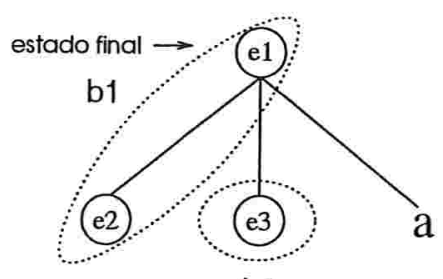

b3

Figura 3.4: À esquerda um autômato a árvore com partição inicial. À direita o mesmo autômato a árvore após o agrupamento dos blocos $b_{1}$ e $b_{2}$.

Intuitivamente, um autômato a árvore é uma árvore onde nós internos são denominados 
estados e as folhas são símbolos de um alfabeto. O nó raiz é denominado estado final. O conjunto de estados é particionado em blocos. Agrupar dois blocos $b_{1}$ e $b_{2}$ significa unir em um único bloco $b_{3}$ os estados de $b_{1}$ e $b_{2}$, e $b_{3}$ substituir $b_{1}$ e $b_{2}$ na partição. Um autômato a árvore é definido pela quádrupla $A=(Q, V, \delta, F)$, onde $Q$ é o conjunto de estados, $V$ é o alfabeto de terminais, $\delta$ é uma função $\delta:(Q \cup V)^{*} \rightarrow Q$ que associa um conjunto de estados e terminais a um estado pai, e $F$ é o conjunto de estados finais.

Quando todos os estados finais de um autômato a árvore pertencem a um único bloco, ele é equivalente a uma gramática. Neste caso, o bloco do estado final equivale ao símbolo inicial, os blocos equivalem aos símbolos não terminais, e os símbolos do alfabeto equivalem ao símbolos terminais. A relação de pai-descendentes, considerando os blocos dos estados, equivale a uma produção. Assim se o estado $e_{1}$ tem como descendentes os estados $e_{2}$ e $e_{3}$ e o símbolo $a$, com $e_{1}$ e $e_{2}$ pertencentes ao bloco $b_{1}$, e $e_{3}$ pertencente ao bloco $b_{3}$, temos a produção: $\langle\mathrm{B} 1\rangle::=\langle\mathrm{B} 1\rangle\langle\mathrm{B} 3\rangle \mathrm{a}$.

Inicialmente, é gerado um autômato a árvore para cada uma das seqüências da amostra. Para cada autômato é criada uma partição de forma que seja criado um bloco para cada estado. Os blocos dos estados finais de todos os autômatos são agrupados, resultando em um único autômato a árvore que reconhece todos os exemplos da entrada (e só eles). A partir desse ponto o algoritmo realiza sucessivos testes e agrupamentos de estados de forma a assegurar as propriedades de reversibilidade. Esses agrupamentos de estados generalizam os exemplos reconhecidos. Ao final dos testes o autômato será reversível e considerado resposta do processo de inferência. A seguir é apresentada uma breve descrição do algoritmo, conforme [Sak92].

Entrada: uma amostra positiva não vazia $S$

Saída: Um autômato reversível A 


\section{Procedimento:}

Crie o autômato a árvore $A=(Q, V, \delta, F)$ formado a partir da amostra $\mathrm{S}$ Crie uma partição trivial $\pi_{0}$ sobre $Q$

$q \leftarrow$ algum estado pertencente a $F$

lista $\leftarrow$ todos os pares $\left(q, q^{\prime}\right)$ onde $q^{\prime} \in F-\{q\}$

$i \leftarrow 0$

enquanto $($ lista $\neq \emptyset)$ faça

remova o primeiro par $\left(q_{1}, q_{2}\right)$ de lista

$\% B\left(q, \pi_{i}\right)$ retorna o bloco do estado $q$ dentro da partição $\pi_{i}$

$B_{1} \leftarrow B\left(q_{1}, \pi_{0}\right)$ e $B_{2} \leftarrow B\left(q_{2}, \pi_{0}\right)$

se $B_{1} \neq B_{2}$

$\pi_{i+1} \leftarrow \pi_{i}$ com $B_{1}$ e $B_{2}$ agrupados

VerificaPropriedade1 $\left(\pi_{i+1}\right)$

VerificaPropriedade $2\left(\pi_{i+1}, B_{1}, B_{2}\right)$

$i \leftarrow i+1$

fim

VerificaPropriedade1 $\left(\pi_{i+1}\right)$ :

para todos os pares de estados $\left(q, q^{\prime}\right) \in Q \times Q$

se $q$ e $q^{\prime}$ têm o mesmo número de descendentes

$$
\begin{aligned}
& q=\operatorname{pai}\left(u_{1}, u_{2}, \ldots, u_{k}\right) \text { e } q^{\prime}=\operatorname{pai}\left(u_{1}^{\prime}, u_{2}^{\prime}, \ldots, u_{k}^{\prime}\right) \\
& \text { se }\left(\left(u_{j}, u_{j}^{\prime} \in Q \text { e } B\left(u_{j}, \pi_{i+1}\right)=B\left(u_{j}^{\prime}, \pi_{i+1}\right)\right) \text { ou } u_{j}=u_{j}^{\prime} \in V\right) \text { para } 1 \leq j \leq \mathrm{k} \\
& \text { e } B\left(q, \pi_{i+1}\right) \neq B\left(q^{\prime}, \pi_{i+1}\right) \\
& \quad \text { adicione o par }\left(q, q^{\prime}\right) \text { à lista }
\end{aligned}
$$

\section{VerificaPropriedade $2\left(\pi_{i+1}, B_{1}, B_{2}\right)$ :}

para todos os pares de estados $\left(q, q^{\prime}\right) \in B_{1} \times B_{2}$

se $q$ e $q^{\prime}$ têm o mesmo número de descendentes

$$
\begin{aligned}
& q=\operatorname{pai}\left(u_{1}, u_{2}, \ldots, u_{k}\right) \text { e } q^{\prime}=\operatorname{pai}\left(u_{1}^{\prime}, u_{2}^{\prime}, \ldots, u_{k}^{\prime}\right) \\
& \text { se }\left(\left(u_{l}, u_{l}^{\prime} \in Q \text { e } B\left(u_{l}, \pi_{i+1}\right) \neq B\left(u_{l}^{\prime}, \pi_{i+1}\right)\right) \text { para algum } 1(1 \leq 1 \leq \mathrm{k})\right. \\
& \text { e } B\left(u_{j}, \pi_{i+1}\right)=B\left(u_{j}^{\prime}, \pi_{i+1}\right) \text { ou } u_{j}=u_{j}^{\prime} \in V, \text { para } 1 \leq j \leq \mathrm{k}, j \neq 1 \\
& \quad \text { adicione o par }\left(u_{l}, u_{l}^{\prime}\right) \text { à lista }
\end{aligned}
$$


Este algoritmo tem complexidade $O\left(n^{3}\right)$, onde $n$ é o número de parentisações sobre as seqüências da amostra de treinamento [Sak92]. Cada parentisação corresponde a um estado do autômato a árvore.

\subsubsection{Algoritmo para inferência de gramáticas tipo-inversíveis}

O algoritmo descrito em [Mak92] também combina as estratégias de considerar uma subclasse de GLCs, e a de utilização de exemplos estruturais. A subclasse considerada, porém, é a de GLCs tipo-inversíveis. Mäkinen também utiliza um autômato a árvore e uma outra estrutura chamada trie.

Definição 18 : Uma trie é uma dupla $T=(N, E)$ onde:

- $N$ é um conjunto finito de nós;

- E é um conjunto finito de arestas;

- uma aresta e $\in E$ é uma tripla $\left(n_{1}, n_{2}, r\right)$, que conecta os nós $n_{1}$ e $n_{2}, n_{1}, n_{2} \in N$, e possui rótulo $r$.
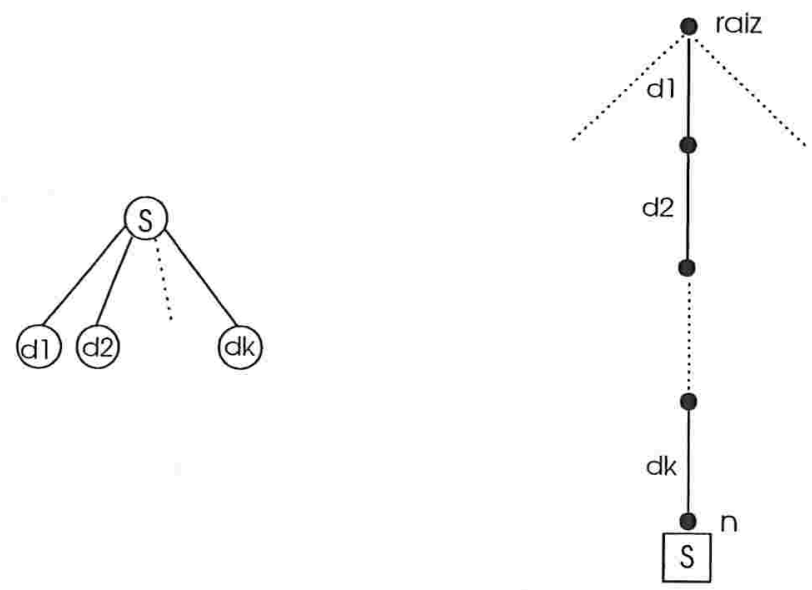

Figura 3.5: Correspondência entre um estado $s$ de um autômato a árvore e um caminho da raiz ao nó $n$ em uma trie equivalente 
Mäkinen utiliza a estrutura trie de forma que cada nó possa possuir um mais objetos ${ }^{8}$ associados. A trie é criada de forma que seja correspondente ao autômato a árvore criado a partir das seqüências de entrada. Para isso, os rótulos das arestas são rótulos de estados e terminais de um autômato a árvore. Os objetos associados aos nós são estados deste autômato. Essa associação pode ser feita da seguinte forma: para cada estado $s$ do autômato $A$ com descendentes $d_{1}, d_{2}, \ldots, d_{k}$, existe um caminho $p$ na trie $T$ que vai da raiz a um nó $n$ onde:

- o estado $s$ está associado o nó $n$;

- o caminho $p$ é formado por $k$ arestas rotuladas $d_{1}, d_{2}, \ldots, d_{k}$, nesta ordem, da raiz ao nó $n$.

Dessa forma, um estado $s$ do autômato é associado a um nó $n$ da trie se a seqüência dos rótulos dos descendentes de $s$ corresponde à seqüência dos rótulos das arestas contidas no caminho do nó raiz até o nó $n$, conforme mostra a figura 3.5.

No algoritmo, porém as arestas são rotuladas de forma diferenciada. Para efetuar a nova rotulação, basta trocar os rótulos dos estados pelo rótulo $n$ e trocar os rótulos dos terminais pelo rótulo $t$. O novo rótulo é dado pela aplicação do homomorfismo $h$ descrito na seção 3.3.3 sobre gramáticas tipo-inversíveis. De cada nó não podem partir duas arestas com o mesmo rótulo. Caso isso aconteça, estas devem ser agrupadas. Para isso basta agrupar os nós destinos das arestas. A figura 3.6 mostra como seria o processo de criação de uma trie a partir de um autômato e sua nova rotulação.

O algoritmo constrói um autômato a árvore a partir das seqüências de entrada. Uma trie é criada a partir desse autômato inicial, já com o novo procedimento de rotulação. Seguindo a mesma idéia de algoritmo de Sakakibara, algumas propriedades são definidas sobre essa trie de forma que esta corresponda a um autômato a árvore tipo-inversível. Estas propriedades são de R-separabilidade e inversibilidade de produções terminais, conforme vimos na seção 3.3.3 sobre gramáticas tipo-inversíveis. Para assegurar essas propriedades, as manipulações sobre essa trie podem levar a agrupamentos de estados do autômato a árvore. Ao final do algoritmo, a trie satisfaz todas a propriedades de tipo-inversibilidade, assim como o autômato. Esse autômato é então considerado resposta do processo de inferência.

\footnotetext{
${ }^{8} \mathrm{O}$ termo objeto é aqui utilizado para designar um dado genérico.
} 

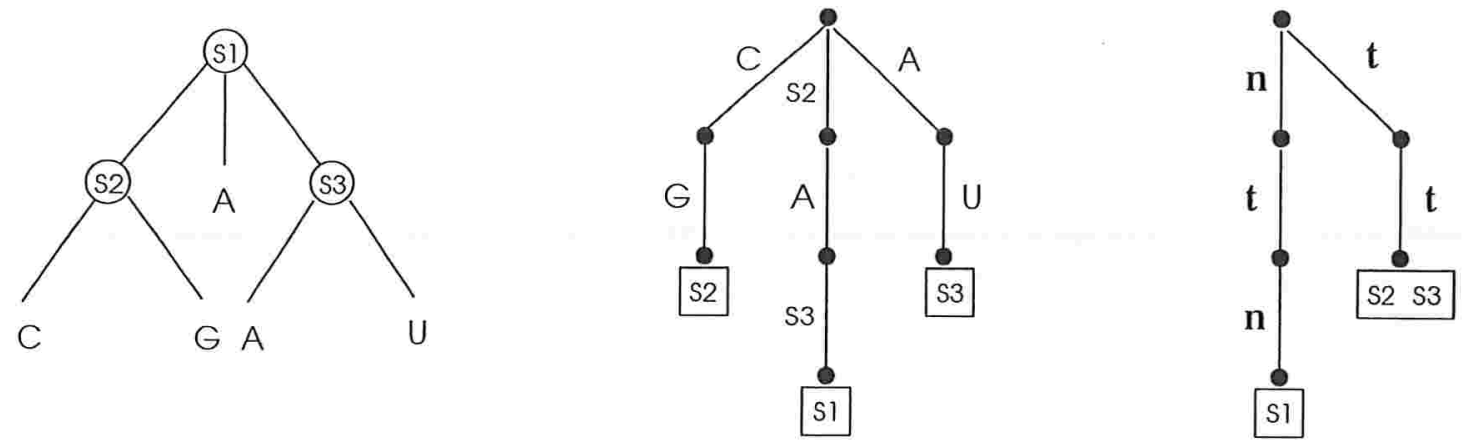

Figura 3.6: Um autômato, sua trie correspondente e sua trie com nova rotulação

A seguir é apresentada uma breve descrição do algoritmo.

Entrada: uma amostra positiva não vazia S

Saída: Um autômato reversível A

\section{Procedimento:}

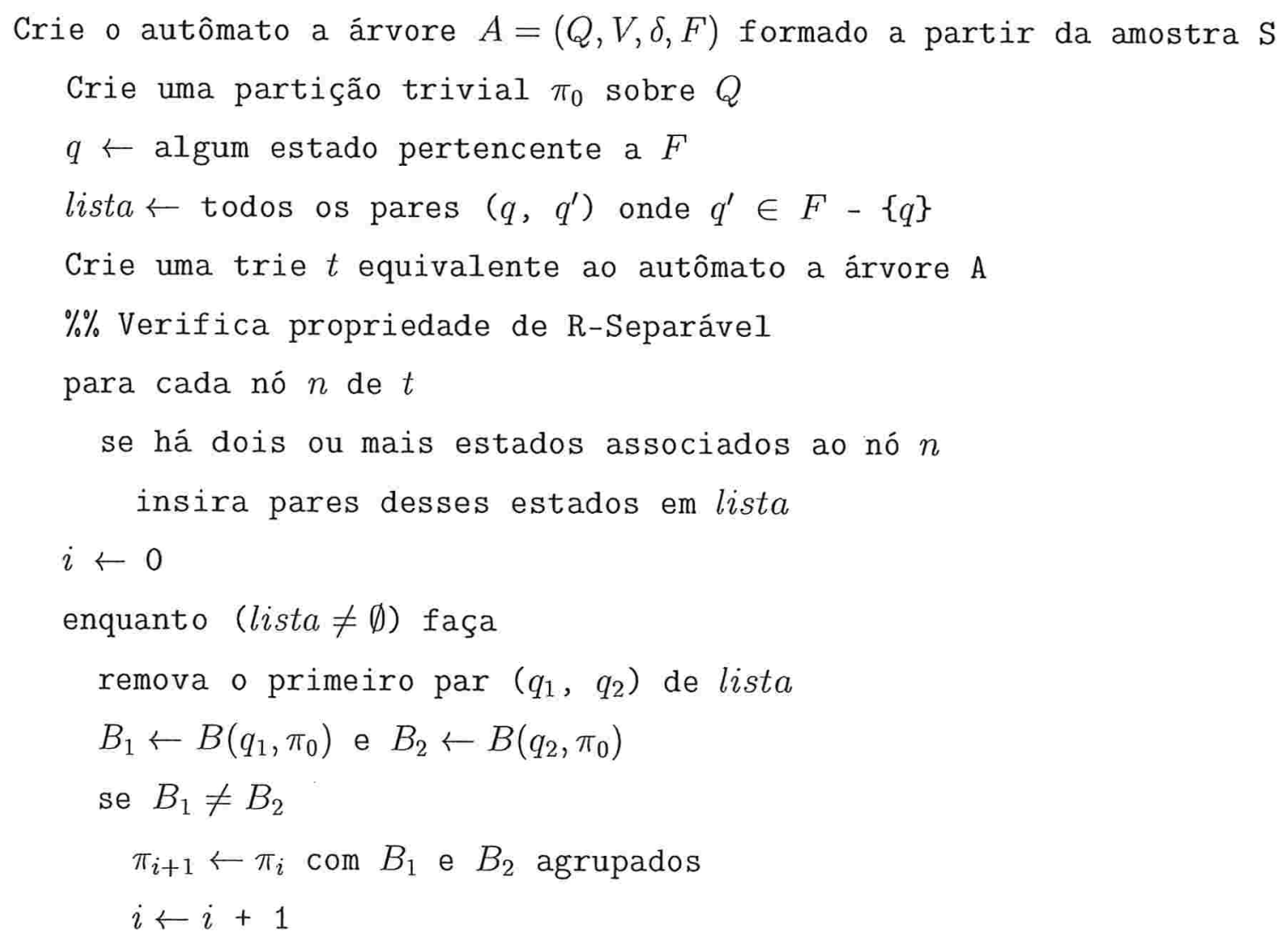


fim

Este algoritmo tem complexidade $O(n)$, onde $n$ é o número de parentisações sobre as seqüências da amostra de treinamento [Mak92]. Cada parentisação corresponde a um estado do autômato a árvore. 


\section{Estimação de parâmetros de GLCEs}

O processo de inferência de gramáticas estocásticas é normalmente dividido em duas etapas: identificação da gramática não estocástica e estimação das probabilidades de suas produções. No capítulo 3 foi tratada a etapa de identificação da gramática não estocástica. Neste capítulo será tratada a etapa de estimação das probabilidades.

Os algoritmos estudados partem da existência de uma gramática inicial, mas diferem em considerar se essa já deva ser estocástica ou não. A fim de explorar a estrutura necessária para as duas estratégias, foram selecionados para implementação um algoritmo de cada. $\mathrm{Na}$ seção 4.1 é descrito um algoritmo que será chamado $E P_{F u}$, que parte de uma gramática não estocástica, realizando a estimação em um único passo a partir da amostra de treinamento. Na seção 4.2 é descrito o algoritmo chamado $E P_{T G R}$, que assume que essa gramática inicial já possui probabilidades iniciais. Essas probabilidades são utilizadas como ponto de partida de um processo de reestimação das mesmas até alcançarem um ponto de convergência.

O algoritmo $E P_{F u}$ possui uma base teórica mais simples. Ele faz uma contagem do uso das produções durante a análise das seqüências de treinamento, considerando também as freqüências dessas seqüências na amostra. Estas seqüências de treinamento não precisam conter informação estrutural.

O algoritmo $E P_{T G R}$ baseia-se em conceitos estatísticos mais sofisticados, utilizados em aprendizado computacional. Trata-se de um processo de reestimação das probabilidades que busca alcançar uma estabilização desses valores. Utiliza como amostra de treinamento seqüências com informações estruturais.

O capítulo 5 apresenta como esses algoritmos foram modelados no arcabouço. 


\subsection{Estimação de passo único}

K. S. Fu [Fu82] propõe um algoritmo simples para estimar as probabilidades de uma gramática inicialmente não estocástica a partir de uma amostra de treinamento. Para isso o algoritmo assume que essa amostra possui a mesma distribuição de probabilidades da linguagem estocástica desconhecida ${ }^{1}$ [AS83]. Dessa forma, a freqüência das cadeias na amostra colabora na estimação de suas probabilidades dentro dessa linguagem.

Nesse algoritmo cada produção da gramática possui um contador de uso, inicialmente igual a zero. É realizada a análise sintática ${ }^{2}$ (segundo essa gramática) de cada seqüência da amostra de treinamento. Cada vez que uma produção é utilizada durante o processo de análise seu contador é incrementado. Após analisar todas as seqüências da amostra, os valores desses contadores são normalizados de forma que cada produção tenha uma probabilidade entre 0 e 1 , e que a somatória das probabilidades das produções com o mesmo lado esquerdo seja igual a 1.

Formalmente, dada uma amostra de treinamento $S=\left\{x_{1}, x_{2}, \ldots, x_{n}\right\}$ e uma gramática $G$ com produções $A_{i} \rightarrow \alpha_{j}$, onde $A_{i} \in V_{n}$ e $\alpha_{j} \in\left(V_{n} \cup V_{t}\right)^{*}$, a probabilidade estimada $\hat{p}_{i j}$ de cada produção é dada por

$$
\hat{p}_{i j}=n_{i j} / \sum_{j} n_{i j}
$$

$$
\text { onde } n_{i j}=\sum_{x_{k} \in S} n_{i j}\left(x_{k}\right)
$$

onde $n_{i j}\left(x_{k}\right)$ é o número de vezes que a produção $A_{i} \rightarrow \alpha_{j}$ foi utilizada na análise da seqüência $x_{k}$.

Assumindo que a amostra de treinamento possui a mesma distribuição de probabilidades da linguagem desconhecida, a probabilidade estimada $\hat{p}_{i j}$ aproxima $p_{i j}$ à medida que o número de seqüências $n$ que compõem a amostra de treinamento tende ao infinito.

\footnotetext{
${ }^{1}$ Note que o modelo PAC learning de aprendizado computacional também assume essa hipótese.

${ }^{2}$ Para esta implementação foi utilizado o algoritmo de Earley [Ear70].
} 


\subsection{Tree Grammar Reestimator}

Sakakibara [SBU $\left.{ }^{+} 93, \mathrm{Mic} 93, \mathrm{SBU}^{+} 94, \mathrm{SBH}^{+} 94 \mathrm{a}\right]$ propôs um algoritmo chamado Tree Grammar Reestimator. Este generaliza um algoritmo de estimação de probabilidades de uma cadeia de Markóv escondida, ou HMM (Hidden Markov Model), conhecido como forwardbackward [Bak79]. O algoritmo TGR assume que é dada uma gramática inicial com as probabilidades das produções inicializadas ${ }^{3}$. A partir de uma amostra de treinamento, essas probabilidades são reestimadas a partir de um método EM (Expectation - Maximization) [Bau72]. O algoritmo tem complexidade $O\left(n^{2}\right)$, onde $n$ é o tamanho típico de uma seqüência [Mic93]. A aplicação desse algoritmo na modelagem de RNAs pode ser encontrada em [SBU+93, Mic93, SBU $+94, \mathrm{SBH}^{+} 94 \mathrm{a}, \mathrm{SBH}^{+}$94b, Und94].

\subsubsection{Algoritmos EM}

Um algoritmo EM é um algoritmo iterativo que alterna passos de cálculo de expectativa e de maximização. Algoritmos desse tipo são muito úteis em problemas de estimação de parâmetros cujo modelo possui dados e variáveis desconhecidas, não observadas [BB01]. Essas variáveis são chamadas variáveis escondidas. Como não são conhecidas possíveis variáveis na modelagem de um grande número de fenômenos biológicos, essa estratégia é muito utilizada em biologia computacional, principalmente através da aplicação de HMM.

Algoritmos EM consideram a existência de dois conjuntos de variáveis. O conjunto $D$ é composto pelas variáveis conhecidas do modelo, enquanto o conjunto $H$ é composto pelas variáveis escondidas. O modelo possui inicialmente um conjunto de parâmetros ${ }^{4} \omega$. A cada iteração são executados os passos E (expectation) e M (maximization), resultando em uma nova estimação de $\omega$. No passo $\mathbf{E}$, é calculado $P\left(H \mid D, \omega^{t-1}\right)$, que é a distribuição de probabilidades sobre o espaço $H$ das variáveis escondidas levando em consideração as variáveis observadas e os parâmetros calculados no passo anterior. No passo M, $\omega$ é recalculado de forma a maximizar $P(H, D \mid \omega)$, aumentando a probabilidade dos dados observados com a nova parametrização.

O algoritmo executa várias iterações alternando fases E e M até que a parametrização se torne estável, ou seja, até que os valores de $\omega$ apresentem uma baixa variação em relação

\footnotetext{
${ }^{3} \mathrm{~A}$ inicialização das probabilidades pode inclusive levar em consideração algum conhecimento bioquímico.

${ }^{4}$ No caso de GLCEs, esses parâmetros são as probabilidades das produções.
} 
aos valores calculados na iteração anterior. Não encontramos na literatura maiores detalhes sobre um método de cálculo e análise dessa variação na parametrização.

\subsubsection{O algoritmo TGR}

O algoritmo Tree Grammar Reestimator [SBU+93] é um algoritmo EM que visa modelar uma família de seqüências através de uma gramática estocástica. As variáveis no modelo de gramáticas são as produções, enquanto os parâmetros são as probabilidades das produções.

As variáveis conhecidas $(D)$ estão representadas pelas produções da gramática inicial. A parametrização $\omega$ é o conjunto de probabilidades dessas produções. As variáveis escondidas representam tudo aquilo que ainda não se conhece do modelo, como produções não inseridas por falta de conhecimento.

Para compor a amostra de treinamento é utilizado um conjunto de seqüências com informações estruturais. Essas seqüências são manipuladas em formato de árvore ${ }^{5}$ de forma a descrever sua estrutura. As folhas representam os caracteres da seqüência, enquanto os nós internos, que devem ser numerados, representam a estrutura descrita pelos parêntesis. Assim a seqüiência $((\mathrm{a}(\mathrm{gc}) \mathrm{u})(\mathrm{a}(\mathrm{gc}) \mathrm{u})$ é representada pela árvore da figura 4.1.

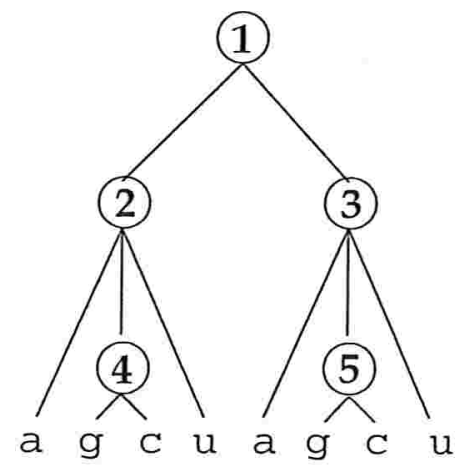

Figura 4.1: Árvore da cadeia $((\mathrm{a}(\mathrm{cg}) \mathrm{u})(\mathrm{a}(\mathrm{cg}) \mathrm{u}))$

Dada uma árvore $t$ e um nó $n$, é denotada $t / n$ a sub-árvore de $t$ com raiz em $n$ (veja o lado esquerdo da figura 4.2), e é denotada $t \backslash n$ a árvore que sobra da árvore $t$ após a remoção de $t / n$ mantendo o nó $n$ (veja o lado direito da figura 4.2).

\footnotetext{
${ }^{5} \mathrm{Da}$ mesma forma que no algoritmo de inferência RT.
} 

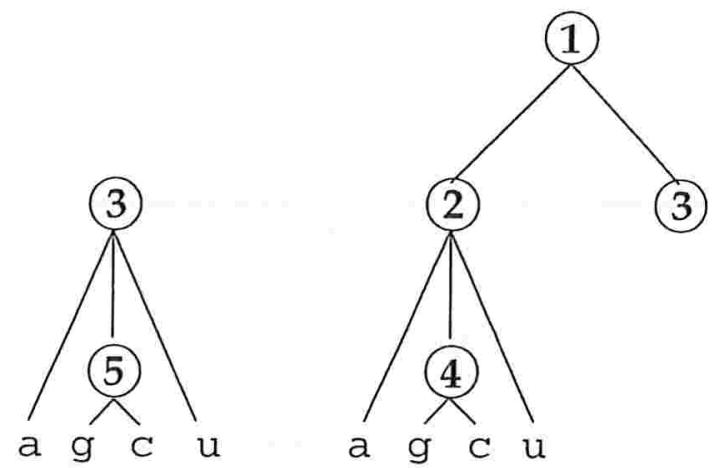

Figura 4.2: $\AA$ esquerda $t / 3$ e à direita $t \backslash 3$

Considere agora a seguinte gramática estocástica:
$\mathrm{S} \rightarrow \mathrm{AA} \quad 1$
$\mathrm{A} \rightarrow \mathrm{aBu} \quad 0.1$
$\mathrm{A} \rightarrow \mathrm{uBa} \quad 0.2$
$\mathrm{A} \rightarrow \mathrm{cBg} \quad 0.3$
$\mathrm{A} \rightarrow \mathrm{gBc} \quad 0.4$
$\mathrm{B} \rightarrow \mathrm{au} \quad 0.1$
$\mathrm{B} \rightarrow$ ua $\quad 0.2$
$\mathrm{B} \rightarrow \mathrm{cg} \quad 0.3$
$\mathrm{B} \rightarrow \mathrm{gc} \quad 0.4$

Com essa representação, a sub-árvore $t / 3$ pode ser associada ao símbolo A da gramática, pois o nó 3 possui como descendentes (a 5 u) enquanto o símbolo A deriva aBu, e recursivamente $t / 5$ pode ser associada ao símbolo B. Pode-se associar valores de probabilidade a sub-árvores utilizando as probabilidades das produções utilizadas na associação. Assim a sub-árvore $t / 3$ receberá um valor igual a 0.1 x $0.4=0.04$ (0.1 da produção $A \rightarrow a B u$, e 0.4 da produção $B \rightarrow$ gc). Note que $t / 1$ é a probabilidade da seqüência segundo a gramática considerada.

Utilizando essa noção é definido o valor $i n[n, S]$, que representa o valor de $t / n$ ao ser associada ao símbolo $S$. A intuição do cálculo é que, se $S$ está associado a um nó $n$, então cada símbolo do lado direito de $S$ deve estar associado a cada descendente de $n$, na ordem 
da esquerda para a direita na produção e na árvore, respectivamente. Portanto, os valores destas associações devem ser levados em consideração no cálculo do valor da associação do símbolo do lado esquerdo $S$ ao nó pai $n$. Este valor é calculado recursivamente por:

- $i n[n, X]=1$ para todos os nós folhas $n$ e terminais $X$ onde $n$ coincide com $X$.

- $i n[n, X]=0$ caso $n$ não coincida $\operatorname{com} X$.

- para todos os não terminais $S$, todos os nós internos $m$, e todos os nós filhos de $m$ $n_{1}, \ldots, n_{k}$

$$
\operatorname{in}[m, S]=\sum_{S \rightarrow Y_{1} \ldots Y_{k} \in P_{S}} i n\left[n_{1}, Y_{1}\right] * \ldots * i n\left[n_{k}, Y_{k}\right] * P\left(S \rightarrow Y_{1} \ldots Y_{k}\right)
$$

onde $P_{S}$ é o conjunto de produções contendo o símbolo $S$ como lado esquerdo.

Da mesma forma é possível associar $t \backslash n$ a um não terminal. No exemplo acima, $t \backslash 3$ pode também ser associado ao símbolo $\mathrm{A}$, pois os descendentes do nó pai do nó 3 são (2 3), A aparece em uma produção $\mathrm{S} \rightarrow \mathrm{AA}, \quad t / 2$ pode ser associado a $\mathrm{A}$ (ao primeiro A do lado direito da produção) e recursivamente $t \backslash 1$ pode ser associado ao símbolo $\mathbf{S}$.

É definido então o valor out $[n, S]$, que representa o valor de $t \backslash n$ ao ser associada ao símbolo $S$. Da mesma forma que no cálculo de in, se um símbolo $S$ está associado a um nó $n$, então os demais símbolos do lado direito da produção onde $S$ aparece devem estar associados aos nós irmãos de $n$. Além disso, o símbolo do lado esquerdo da produção que contém $S, S^{\prime}$, deve estar associado ao nó $l$, pai de $n$. Este valor é calculado recursivamente por:

- para o nó raiz $n$, out $[n, S]=1$ se $S$ for o símbolo inicial out $[n, S]=0$ caso contrário

- para todos os não terminais $S$, todos os nós internos $l$ e $m$ onde $l$ é pai de $m$, e todos os nós irmãos de $m n_{1}, \ldots, n_{k}$

$$
\operatorname{out}[m, S]=\sum_{S \rightarrow Y_{1} \ldots Y_{k} \in W_{S}, S^{\prime} \in V_{n}} i n\left[n_{1}, Y_{1}\right] * \ldots * i n\left[n_{k}, Y_{k}\right] * P\left(S^{\prime} \rightarrow Y_{1} \ldots S \ldots Y_{k}\right) * \text { out }\left[l, S^{\prime}\right]
$$

onde $W_{S}$ é o conjunto de produções contendo o símbolo $S$ no lado direito. 
Este estimador recebe uma amostra de seqüências que serão representadas por árvores. Assim, para cada árvore, é mantida uma matriz in para armazenar seus valores de $i n[n, S]$, e uma matriz out para armazenar seus valores de out $[n, S]$.

Como já foi dito, o algoritmo Tree Grammar Reestimator é um algoritmo EM. No passo E são calculadas as probabilidades de todas as seqüências da amostra de treinamento. Para isso é utilizada a gramática conhecida $G$ e os parâmetros (probabilidades das produções) calculados na iteração anterior. Durante esse processo os valores das tabelas in e out são recalculados. Isso é feito utilizando os cálculos indutivos descritos acima.

No passo M são recalculadas as probabilidades de todas as produções da gramática $G$ de forma a ajustarem-se aos novos valores das tabelas in e out. Para cada produção $S \rightarrow Y_{1} \ldots Y_{k}$, sua nova probabilidade deve ser baseada nos valores in e out das possíveis associações do símbolo $S$ a todos os nós $m$ de todas as seqüências $t$. Devem ser consideradas também a probabilidade atual da produção e a probabilidade das seqüências. Trata-se de uma medida de quanto essa produção é usada na análise das seqüências de treinamento. Essa nova probabilidade é calculada com base em todos os nós $m$ de todas as seqüências $t$ :

$$
\left.\left(\sum_{t}\left(\sum_{n \text { os } m} \operatorname{out}[m, S] * P\left(S \rightarrow Y_{1} \ldots Y_{k}\right) * i n\left[n_{1}, Y_{1}\right] * \ldots * i n\left[n_{k}, Y_{k}\right] / P(t \mid G)\right)\right)\right) / \text { norm }
$$

onde $P(t \mid G)=i n[n, S]$ sendo $n$ o nó raiz da seqüência $t$ e $S$ o símbolo inicial da gramática $G$, e norm um fator de normalização ${ }^{6}$.

Os passos E e $M$ devem ser repetidos até que as probabilidades das produções não apresentem variação de um passo para outro.

A seguir é apresentado um esquema geral do algoritmo que utiliza os cálculos apresentados.

\footnotetext{
${ }^{6}$ Esta normalização deve fazer com que cada produção tenha uma probabilidade entre 0 e 1 , e que a somatória das probabilidades das produções de um mesmo não terminal seja igual a 1. Para isso, a cada não terminal $S$, norm deve ser a soma dos valores atribuídos às probabilidades das produções de $S$.
} 
Entrada: uma amostra positiva com informações estruturais e uma gramática $g$ com probabilidades iniciais

Saída: Uma gramática estocástica

Procedimento:

TGR()

faça

para cada produção $r$

novaP $\leftarrow 0 \quad \%$ nova probabilidade da produção $r$

para cada sequencia $s$ da amostra

$p s \leftarrow$ in (raiz $(s)$, simboloInicial $(g))$ probabilidade da sequiência

parcial $\leftarrow 0$

para cada nó $n$ de $s$

parcial $\leftarrow \operatorname{parcial}+\operatorname{out}(n, r) * \operatorname{probabilidade}(r) * \operatorname{ins}(n, r)$

novaP $\leftarrow$ novaP + parcial $/ p s$

\% divide os valores calculados pelo fator de normalização

normalizaProbabilidades ()

enquanto (estabilizou $(d, k)=$ falso);

ins $(n, r)$

\%Calcula o produto de in $(m, y)$, onde $m$ e $y$ são, respectivamente,

\%nó filho de $n$ e símbolo do lado direito da produção $r$

parcial $\leftarrow 1$

se numeroDeDescendentes $(n)=$ numeroSimbolosDoLadoDireito $(r)$

para $i$ de 1 ate numeroDeDescendentes $(n)$

parcial $\leftarrow$ parcial $*$ in (i-ésimoDescendente $(n)$, i-ésimoSimbolo $(r)$ )

senão parcial $\leftarrow 0$

retorna parcial 


\subsection{Observações sobre os estimadores}

O fato do $E P_{F u}$ não utilizar seqüências com informações estruturais possibilita a utilização de amostras de treinamento maiores. Por exemplo, se são disponíveis 50 seqüências de uma determinada família, mas é conhecida a estrutura de apenas 30 delas, é possível utilizar essas 30 para inferir a gramática não estocástica ${ }^{7}$ e as 50 para estimar suas probabilidades.

Poderia ser explorado o uso de $E P_{F u}$ para estimar as probabilidades iniciais da gramática estocástica utilizada por $E P_{T G R}$. Algoritmos EM convergem para um máximo local [BB01]. Poderia, portanto, ser investigado se o $E P_{F u}$ é capaz de fornecer uma inicialização de forma a alcançar uma gramática estocástica que incremente a probabilidade das seqüências pertencentes à família considerada. No entanto este tipo de teste não foi realizado neste trabalho.

\footnotetext{
${ }^{7}$ Considerando que, até o momento, foram implementados somente algoritmos de inferência que exigem seqüências com informações estruturais como amostra de treinamento.
} 



\section{Implementação do arcabouço}

\subsection{Arquitetura básica}

Além da implementação do arcabouço, foi adicionada à proposta a implementação de alguns desses algoritmos, com a finalidade de testar a arquitetura do arcabouço e fazer uma avaliação preliminar da aplicação de gramáticas livres de contexto estocásticas na modelagem de algumas estruturas biológicas.

Durante a elaboração da arquitetura foi considerada a utilização de uma linguagem que facilite a reutilização de código, a flexibilidade de implementação e a expansibilidade. Por esse motivo foi o escolhido o paradigma de programação orientada a objetos (POO) para implementar nosso arcabouço. Com POO torna-se mais fácil, por exemplo, implementar novas opções de algoritmos utilizando herança e encapsular complexidades de componentes. Procurou-se, sempre que possível, aplicar padrões de desenho orientado a objetos [GHJV99] com a finalidade de aumentar a generalidade e flexibilidade da arquitetura.

Este sistema será adicionado futuramente a um ambiente de desenvolvimento, o Matlab ${ }^{1}$. Para isso a linguagem de programação escolhida foi $\mathrm{C}++$. A escolha dessa plataforma devese à ligação desse trabalho ao grupo de pesquisa CAGE, no qual o acesso das aplicações à sua base de dados é realizado via Matlab.

\footnotetext{
${ }^{1}$ Matlab (Matrix Laboratory) é uma plataforma que combina interface, linguagem, funções matemáticas, funções gráficas e outras ferramentas que auxiliam problemas como visualização e processamento de imagens, análise e exploração de dados, simulações e desenvolvimento de aplicações. Essas aplicações desenvolvidas podem ser integradas à plataforma a fim de extender suas funcionalidades. Apesar de possuir uma linguagem própria, aplicações $\mathrm{C}$ e $\mathrm{C}++$ podem ser também ser integradas facilmente. A página do Matlab na internet é http://www.mathworks.com/products/matlab/index.shtml
} 
A proposta do laboratório tem como objetivo facilitar a pesquisa da aplicação de vários algoritmos de aprendizado de gramáticas estocásticas na modelagem de seqüências biológicas. Para realizar essa pesquisa é necessário implementar os algoritmos a serem estudados, compôlos em um processo para geração dos classificadores, testar os classificadores resultantes, para então fazer uma análise sobre os resultados obtidos. Por isso este tarabalho propõe um arcabouço composto por três parte:

- algoritmos de inferência gramatical e estimação de probabilidades;

- suporte de implementação;

- suporte de testes.

A primeira parte é formada pelos componentes responsáveis pelo aprendizado de gramáticas estocásticas. Foram caracterizadas classes abstratas de inferidores gramaticais e de estimadores de probabilidades com uma interface definida. Os algoritmos implementados, para serem utilizados no processo de geração de classificadores, devem ser implementados como uma classe $\mathrm{C}++$ que herde ${ }^{2}$ dessas classes abstratas. Há duas classes concretas que implementam inferidores e duas classes concretas que implementam estimadores. Como as duas implementações dos inferidores possuem código em comum, parte de suas funcionalidades encontra-se em uma superclasse abstrata.

A segunda parte tem como objetivo dar suporte à implementação dos algoritmos inferidores e estimadores que comporão o primeiro módulo. Estudando esses algoritmos, foram percebidas algumas estruturas que poderiam ser reutilizadas. A primeira estrutura que claramente seria muito usada seria uma que implementasse gramáticas. Tarefas como criação de gramáticas, manipulação e impressão de sua estrutura são exigidas com freqüência, e não são simples de serem implementadas. Foi criada então uma classe que implementa a noção de gramáticas, encapsulando suas estruturas e definindo os métodos necessários para manipulálas. Outros algoritmos também possuem em comum a utilização de uma estrutura de dados conhecida como autômato a árvore [Sak90], [NSB00], [CO97],[Ang82], [LY90]. Por isso implementamos a classe TreeAutomaton e agregamos à infra-estrutura de software. O mesmo foi feito com a classe Trie, que implementa a estrutura de trie. Embora encontrada em apenas um algoritmo [Mak92], apresenta uma estrutura genérica que permite sua utilização

\footnotetext{
${ }^{2}$ Mecanismo de herança de orientação a objetos.
} 
em outro algoritmo [Sak92], por isso foi adicionada a este módulo de apoio. Como um dos desafios desta proposta é desenvolver uma comunicação abstrata entre os algoritmos, foi adicionado neste módulo de suporte uma coleção de classes que sirva de canal de comunicação entre eles de modo que também permita o armazenamento de resultados intermediários e que seja independente de formatos. Para isso implementamos a coleção Streams de classes que modelam streams ${ }^{3}$ de entrada e saída, uma vez que a biblioteca de templates $\mathrm{C}++$ STL (Standard Template Library) não oferece uma solução apropriada para os requisitos desejados 4 .

Gerar um classificador significa gerar um programa que seja capaz de obter as probabilidades das seqüências analisadas pelas gramáticas aprendidas, para então decidir sua classificação. Para isso é necessária a existência de um analisador sintático para cada uma dessas gramáticas. Como este trabalho trata com GLCEs e que podem ser ambíguas, esses analisadores devem fornecer todas as derivações de uma seqüência, a fim de efetuar o cálculo de sua probabilidade. Por isso não é possível o uso de um gerador de analisadores como o YACC ou suas variações. Para gerar os analisadores necessários implementamos a classe GAna, que foi agregada a este parte auxiliar. Para integrar todos os analisadores das gramáticas consideradas na classificação criamos o componente GC, que se propõe a ser o gerador do classificador final.

De posse da implementação de algoritmos inferidores e estimadores, tem-se os recursos necessários para compor geradores de classificadores e testá-los. Para auxiliar as tarefas de composição e testes destes algoritmos, foi criada a terceira parte. Este é composto por programas Perl e $\mathrm{C}++$ que tratam a geração dos classificadores, a execução dos testes e a obtenção dos resultados.

Para facilitar a avaliação das classificações foram utilizados dados simulados tanto no treinamento das gramáticas quanto nos testes dos classificadores, a fim de possuir conhecimento prévio da classificação das seqüências utilizadas. Para gerar esses dados simulados foi utilizado o programa GS implementado por Caetano Jimenez Carezzato. O GS (Gerador de Seqüências) é capaz de, utilizando métodos probabilísticos, gerar seqüências a partir de uma gramática estocástica livre de contexto.

\footnotetext{
${ }^{3} \mathrm{O}$ termo stream poderia ser traduzido por fluxo. Mas por ser freqüentemente utilizado no meio computacional, este não será traduzido neste trabalho.

${ }^{4}$ Deseja-se especializar classes de streams para leitura dos dados manipulados neste trabalho, como seqüências e gramáticas.
} 
Gerar um classificador significa então gerar amostras de treinamento de vários tamanhos, escolher e compor os algoritmos de aprendizado. Para gerar testes é preciso gerar amostras positivas e negativas ${ }^{5}$ e fazê-las passar pelos classificadores gerados. Obter os resultados significa recolher informações sobre as gramáticas inferidas ${ }^{6}$, sobre quantas seqüências positivas foram reconhecidas, quantas seqüências negativas não foram reconhecidas, e comparar as probabilidades das seqüências de teste analisadas pelas gramáticas inferidas e pela gramática original (utilizada pelo GS para gerá-las).

O processo de geração e testes de um classificador deve ser repetido a partir de amostras de treinamento de diferentes tamanhos, a fim de avaliar a evolução da qualidade de classificação conforme aumentamos a amostra. Portanto os resultados devem ser obtidos das execuções desses vários classificadores. Após o término de todos os testes, essas informações devem ser agrupadas e organizadas em um arquivo respeitando um formato de facilite a análise estatística e geração de gráficos no Matlab.

Para realizar todas essas tarefas de forma automática foram implementados diversos programas simples que compõem um único programa gerador parametrizado. Esses parâmetros são a gramática a ser utilizada no teste, o tamanho mínimo da amostra de treinamento, o tamanho máximo, o intervalo deste tamanho, o intervalo de comprimento das seqüências negativas a serem geradas e um número de vezes que o teste deve ser repetido. Escolhendo os parâmetros desejados, todo o processo de geração dos classificadores e testes é realizado seqüencialmente de modo automático.

Nas próximas seções serão descritos com mais detalhes cada um desses módulos. A seção 5.2 apresenta o módulo que contém os algoritmos de aprendizado. A seção 5.3 apresenta as classes de suporte a implementações. A seção 5.4 apresenta os programas de suporte aos testes.

\subsection{Algoritmos de aprendizado}

Os algoritmos de aprendizado são os responsáveis pela inferência das gramáticas não estocásticas e pela estimação de suas probabilidades. Eles devem ser implementados de forma a poderem ser encaixados no processo de geração de classificadores sem comprometer a

\footnotetext{
${ }^{5}$ Amostras positivas são compostas por seqüências geradas pela gramática de teste, e amostras negativas são compostas por seqüências que não são reconhecidas por essa gramática.

${ }^{6}$ Informações como, por exemplo, número de produções.
} 
interação com o resto do sistema, respeitando interfaces pré-definidas. Para isso foi implementado um componente para os inferidores e um componente para os estimadores. Cada um é composto por uma classe abstrata que define a interface com os demais componentes e por classes concretas que implementam os algoritmos. No caso do componente inferidor a classe abstrata possui também código reutilizável pelas classes concretas implementadas.

A figura 5.1 mostra como se relacionam os componentes de aprendizado gramatical. Uma amostra de treinamento $A$ é fornecida ao inferidor de gramáticas $I G$. Utilizando essa amostra, o $I G$ infere e gera como saída uma gramática não estocástica $G$, que será entrada do estimador de probabilidades EP. Este por sua vez, além de receber essa gramática, recebe também como entrada uma amostra de treinamento, que pode ser a mesma amostra $A$ fornecida ao $I G$. O EP então utiliza essa amostra para estimar as probabilidades de $G$, e gera como saída uma gramática estocástica $G_{e}$.

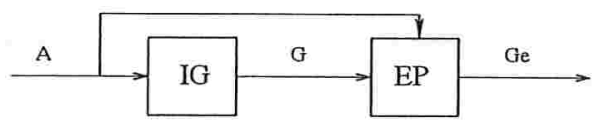

Figura 5.1: Processo de aprendizado de uma gramática estocástica

\subsubsection{Inferidor de Gramáticas (IG)}

O componente IG é formado pelas classes apresentadas na figura 5.2.

A classe abstrata IG é a classe que fornece a interface que deve ser implementada pelos inferidores. Um IG deve receber um conjunto de seqüências e ser capaz de inferir uma gramática não estocástica, fornecendo como saída sua descrição.

Os dois algoritmos, implementados nas classes IgRT e IgMakinen, utilizam a estrutura de autômato a árvore como meio de manipulação de exemplos estruturais. Parte de suas implementações é muito semalhante, podendo ser incorparada a uma superclasse. Como não são todos os inferidores gramaticais que utilizam a estrutura de autômato a árvore ${ }^{7}$, foi criada uma classe abstrata taIG que modela inferidores que o fazem. Para implementar inferidores que não utilizam autômato a árvore, deve-se estender a classe IG.

\footnotetext{
${ }^{7}$ Não encontramos, por exemplo, algoritmos de inferência de gramáticas regulares que façam uso dessa estrutura.
} 


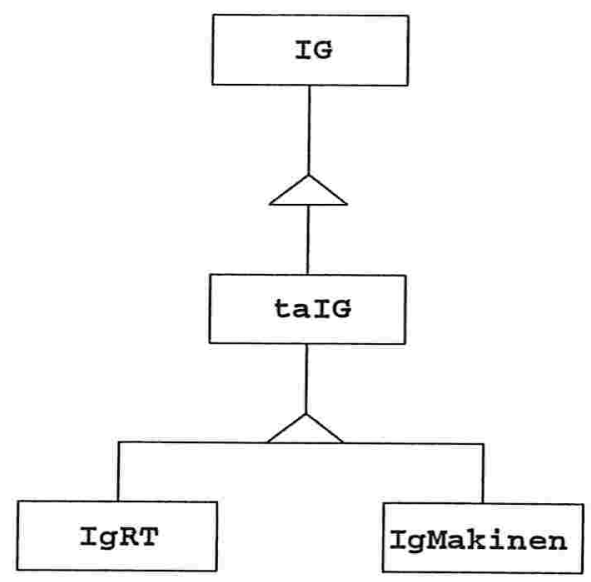

Figura 5.2: UML simplificada de IG

A classe taIG possui métodos concretos e abstratos. O método principal dos dois inferidores foi abstraído em termos de rotinas de manipulação do autômato a árvore. Isso permitiu que ele se tornasse um método concreto de taIG que faz chamadas a métodos concretos e outros abstratos que devem ser implementados pelas subclasses, conforme o algoritmo de inferência.

A seguir é apresentada uma descrição do método principal de inferência:

\% cria um autômato a árvore a partir de um conjunto de seqüências, \% já com os blocos dos estados finais agrupados

ta $\leftarrow$ criaGrandeAutomato() $\%$ método concreto

preProcessaAutomato $(t a) \quad \%$ método abstrato

enquanto exite par de estados a processar

par $\leftarrow$ proximoPar ()$\quad \%$ método concreto

se os blocos de par forem diferentes

processaBlocos (par) \% método abstrato

ta.geraGramatica()

finalizacao() \% método abstrato 


\section{Implementação de IgMakinen}

Esta classe implementa o algoritmo descrito em [Mak92] para inferência de gramáticas livres de contexto tipo-inversíveis. Ela implementa os métodos abstratos definidos na superclasse taIG para manipular o autômato a árvore. Essa manipulação é feita com a ajuda da estrutura de uma trie, conforme descrevemos na seção 3.4.2. Na implementação do método abstrato preProcessaAutomato, a trie é criada e sua associação com o autômato a árvore é feita. Na implementação do método abstrato processaBlocos os dois blocos envolovidos são agrupados em um único, conforme o algoritmo descrito na seção 3.4.2.

\section{Implementação de IgRT}

A classe IgRT implementa o algoritmo descrito em [Sak92] para inferência de gramáticas livres de contexto reversíveis. Ela implementa os métodos abstratos definidos na superclasse taIG, não necessitando de nenhuma estrutura adicional. O método preProcessaAutomato é implementado realizando apenas uma chamada ao método responsável pela verificação da propriedade 1 descrita na seção 3.4.1. O método processaBlocos realiza chamadas ao métodos responsáveis pela verificação da propriedade 1 e 2 , e agrupa os dois blocos envolvidos.

Durante a implementação dessa classe, três problemas não previstos na descrição do algoritmo em [Sak92] tiveram que ser solucionados: alto tempo de execução, inferência de gramáticas não reversíveis e alto consumo de memória.

Tempo de execução Sakakibara [Sak92] descreve este algoritmo como sendo de complexidade $O\left(n^{3}\right)$, onde $n$ é o número total de estados do autômato a árvore utilizado no algoritmo. Com a preocupação com o desempenho do inferidor, durante a implementação foram usados, na medida do possível, alguns artifícios da linguagem $\mathrm{C}++$ como métodos inline, aritmética de ponteiros e serialização de informações para acelerar comparações.

Apesar desses cuidados o tempo de inferência da $G_{t R N A}$ estava muito alto. Os testes foram realizados em um computador contendo um processador Pentium III de $450 \mathrm{MHz}$ e $512 \mathrm{Mb}$ de memória RAM. Para inferir essa gramática a partir de uma amostra de treinamento de 200 seqüências, por exemplo, foram gastos 111585 segundos $^{8}$ (equivalente a 31 horas aproximadamente). Utilizar esse inferidor para gerar gramáticas a partir das amostras

\footnotetext{
${ }^{8}$ Os tempos de execução encontrados nesse trabalho foram obtidos a partir da execução da função time no momento da execução dos algoritmos.
} 


\begin{tabular}{|c|c|c|}
\hline Tamanho da amostra & Número de estados & Tempo de execução \\
\hline \hline 1 & 100 & $0.00 \mathrm{~s}$ \\
\hline 5 & 358 & $0.32 \mathrm{~s}$ \\
\hline 10 & 678 & $3.38 \mathrm{~s}$ \\
\hline 20 & 1303 & $28.05 \mathrm{~s}$ \\
\hline 25 & 1616 & $46.75 \mathrm{~s}$ \\
\hline 50 & 3202 & $102.75 \mathrm{~s}$ \\
\hline 200 & 12759 & $111585.9 \mathrm{~s}$ \\
\hline
\end{tabular}

Tabela 5.1: Primeira fase de execuções de $I G_{R T}$ para $G_{t R N A}$

maiores seria inviável. Na tabela 5.1 é possível notar o crescimento acelerado do tempo de execução com o aumento do tamanho da amostra.

A execução desse algoritmo baseia-se em um loop onde, a cada iteração, blocos de estados são $\operatorname{agrupados}^{9}$ e conseqüentemente novas verificações de reversibilidade devem ser realizadas sobre todos os pares de estados do novo autômato. Estas verificações são efetuadas por dois métodos, um que verifica o determinismo do autômato a árvore, e outro que verifica a propriedade de reset-free do mesmo. O método de verificação de reset-free refaz os testes apenas para os estados dos dois blocos envolvidos no agrupamento, porém o método de verificação de determinismo era executado para todos os pares de estados.

Analisando o algoritmo, foi percebido que o agrupamento de dois blocos só pode comprometer o determinismo nos estados pais dos estados dos blocos agrupados. Dessa maneira, ao agrupar dois blocos, os estados pais dos estados envolvidos no agrupamento passaram a ser armazenados e os testes de verificação de determinismo passaram a ser realizados apenas sobre eles. A nova implementação gastou 46 segundos para inferir a mesma gramática a partir das mesmas 200 seqüências. Para executar sobre 1000 seqüências foram gastos aproximadamente 28 minutos. A tabela 5.2 mostra o tempo de execução dessa nova implementação com vários tamanhos de amostras.

Inferência de gramáticas não reversiveis Apesar de mais rápido, as gramáticas geradas não eram reversíveis como o algoritmo deveria produzir. Após uma nova análise do algoritmo, foi detectada uma falha na descrição do método de verificação de uma das propriedades de

\footnotetext{
${ }^{9}$ Falamos sobre agrupamento de blocos na seção 3.4.1.
} 


\begin{tabular}{|c|c|c|}
\hline Tamanho da amostra & Número de estados & Tempo de execução \\
\hline \hline 100 & 6405 & 0 min7.193s \\
\hline 200 & 12759 & $45.911 \mathrm{~s}$ \\
\hline 300 & 19129 & $1 \mathrm{~min} 33.170 \mathrm{~s}$ \\
\hline 400 & 25530 & $3 \min 20.390 \mathrm{~s}$ \\
\hline 500 & 31866 & $5 \min 7.960 \mathrm{~s}$ \\
\hline 600 & 38182 & $7 \min 21.380 \mathrm{~s}$ \\
\hline 700 & 44578 & $11 \min 38.720 \mathrm{~s}$ \\
\hline 800 & 50920 & $15 \min 16.290 \mathrm{~s}$ \\
\hline 900 & 57206 & $17 \min 57.880 \mathrm{~s}$ \\
\hline 1000 & 63596 & $21 \min 27.630 \mathrm{~s}$ \\
\hline
\end{tabular}

Tabela 5.2: Segunda fase de execuções de $I G_{R T}$ para $G_{t R N A}$

reversibilidade $^{10}$ após o agrupamento de dois estados. Na descrição do algoritmo contida no artigo, este teste apenas analisa os estados envolvidos no agrupamento. Porém, quando dois estados são agrupados, esta propriedade pode ficar comprometida também nos estados pais. Assim a execução do método de verificação foi adicionada aos estados pais dos estados envolvidos no agrupamento. Essa adição foi simples, já que a alteração descrita no parágrafo anterior consiste no reconhecimento desses estados pais.

Corrigido o erro, novas gramáticas foram geradas a partir das mesmas amostras, agora reversíveis. Mesmo com o aumento do número de testes efetuados, não houve comprometimento no tempo de execução total do algoritmo.

Consumo de memória Para manipular o autômato a árvore, o algoritmo mantém uma fila de processamento de pares de estados deste autômato. O processamento de cada par de estados pode levar à inserção de novos pares de estados na fila. Essa fila faz com que o uso de memória do programa inferidor atinja níveis elevados. Para 200 seqüências, por exemplo, essa fila recebeu 424607 inserções de pares de estados. Uma máquina de $512 \mathrm{mb}$ de memória não foi capaz de executar o inferidor a partir de 300 seqüências, mesmo realizando

\footnotetext{
${ }^{10}$ Esta propriedade garante que se $A \rightarrow \alpha B \beta$ e $A \rightarrow \alpha C \beta$ são produções de uma gramática reversível, então $B=C$
} 


\begin{tabular}{|c|c|c|}
\hline Tam. amostra & Número de estados & Tempo de execução \\
\hline \hline 100 & 6405 & $0 \min 7.283 \mathrm{~s}$ \\
\hline 200 & 12759 & $0 \min 37.918 \mathrm{~s}$ \\
\hline 300 & 19129 & $1 \min 32.737 \mathrm{~s}$ \\
\hline 400 & 25530 & $2 \min 43.135 \mathrm{~s}$ \\
\hline 500 & 31866 & $4 \min 32.777 \mathrm{~s}$ \\
\hline 600 & 38182 & $6 \min 51.584 \mathrm{~s}$ \\
\hline 700 & 44578 & $9 \min 53.332 \mathrm{~s}$ \\
\hline 800 & 50920 & $13 \min 35.520 \mathrm{~s}$ \\
\hline 900 & 57206 & $17 \min 14.429 \mathrm{~s}$ \\
\hline 1000 & 63596 & $21 \mathrm{~min} 8.433 \mathrm{~s}$ \\
\hline 2000 & 127065 & $185 \mathrm{~min}$ \\
\hline 3000 & 190312 & $264 \mathrm{~min}$ \\
\hline 4000 & 254452 & $576 \mathrm{~min}$ \\
\hline 5000 & 317969 & $1115 \mathrm{~min}$ \\
\hline 6000 & 380762 & $1786 \mathrm{~min}$ \\
\hline
\end{tabular}

Tabela 5.3: Terceira fase de execuções de $I G_{R T}$ para $G_{t R N A}$

gerenciamento de memória ${ }^{11}$.

O processamento que é realizado sobre um par de estados $\left(e_{1}, e_{2}\right)$ é na verdade realizado apenas sobre os blocos $b_{1}$ e $b_{2}$ onde estão contidos os estados $e_{1}$ e $e_{2}$, respectivamente. A implementação dessa fila foi mudada de forma que um par de estados seja inserido na mesma somente se não existir outro par de estados $\left(e_{3}, e_{4}\right)$ contidos nos blocos $b_{1}$ e $b_{2}$ respectivamente. Para fazer essa verificação foi utilizada uma tabela de hash, com a finalidade de realizar buscas rápidas. A fila criada pelo novo programa inferidor, ao ser executado sobre as mesmas 200 sequiências, recebeu apenas 12759 entradas (contra 424607 da versão anterior). Essa alteração permitiu que o inferidor fosse executado, na mesma máquina, utilizando amostra de tamanho até 1000 seqüências. Os testes com amostras de tamanhos 2000 a 6000 foram realizados em uma Compaq AlphaServer ES40 Alpha, com 2 CPUs de 667 Mhz e 4096 MB de memória RAM. Porém, para uma amostra de tamanho 7000, essa quantidade

\footnotetext{
${ }^{11}$ Executamos um profile e verificamos que o número de chamadas aos destrutores de cada classe é o mesmo número de chamadas aos construtores das mesmas, ou seja, todo objeto criado é destruído.
} 
de memória não foi suficiente e o programa foi abortado pelo sistema.

\subsubsection{Estimador de Probabilidades (EP)}

O componente EP é formado pelas classes apresentadas na figura 5.3.

Este componente tem como finalidade encapsular um algoritmo responsável pela estimação dos parâmetros probabilísticos da gramática gerada pelo componente IG, tornando-a uma gramática estocástica.

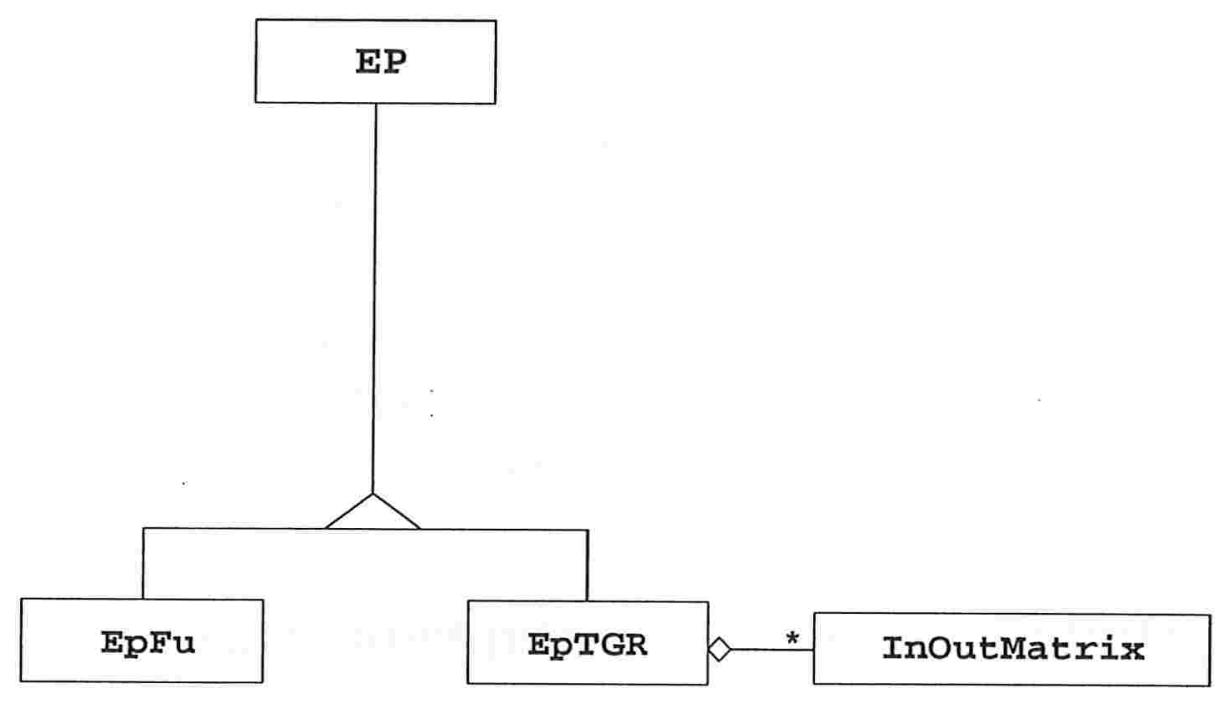

Figura 5.3: UML simplificada de EP

Os dois algoritmos implementados possuem estratégias diferentes, o que não permitiu uma fatoração da implementação do algoritmo. Assim a tarefa da classe abstrata EP é, no momento, definir a interface de integração dos estimadores dos parâmetros probabilísticos da gramática gerada pelo componente IG. Um EP deve receber um conjunto de seqüências e uma descrição de uma gramática não estocástica, e ser capaz de estimar as probabilidades das produções dessa gramática, fornecendo como saída a descrição da gramática estocástica resultante.

\section{Implementação de EpFu}

A classe EpFu implementa o algoritmo desenvolvido por Fu [Fu82], descrito na seção 4.1. 
Esse algoritmo necessita de um analisador sintático para efetuar uma contagem da freqüiência de uso das produções da gramática. Para executar essa tarefa, essa classe utiliza a mesma estrutura do algoritmo de Earley utilizada pelo analisador sintático, pois é preciso considerar todas as árvores de derivação de cada seqüência de treinamento. Por esse motivo foi necessária uma implementação do algoritmo de Earley específica para este fim, não bastando utilizar um gerador de analisadores já implementado como o YACC.

\section{Implementação de EpTGR}

A classe EpTGR implementa o algoritmo reestimador de gramáticas a árvores (Tree Grammar Reestimator) desenvolvido por Sakakibara et.al. [SBU+94], descrito na seção 4.2.

O reestimador de gramáticas a árvores, para manipular as seqüências de treinamento, utiliza também a estrutura de autômatos a árvore, criando um para cada seqüência.

Para efetuar os cálculos de estimação, esse algoritmo utiliza para cada seqüência, duas tabelas: in e out. Para facilitar a manipulação dessas tabelas conforme os cálculos descritos no algoritmo (veja seção 4.2.2), foi implementada a classe InOutMatrix ${ }^{12}$. Dessa forma a cada seqüência estão vinculados um autômato a árvore e um InOutMatrix.

\subsection{Módulo de suporte a implementações}

Algumas das estruturas utilizadas na implementação dos algoritmos de aprendizado são utilizadas em mais de um algoritmo, como por exemplo autômato a árvore e gramáticas. Estas estruturas podem também serem utilizadas em implementações futuras de outros algoritmos. Para facilitar essas implementações foi desenvolvido um conjunto de classes de suporte.

Na seção 5.3.1 é apresentado um conjunto de classes de implementam streams de dados de entrada e saída (InputStream e OutputStream). O objetivo destas classes é prover um canal de comunicação abstrato entre os componentes envolvidos no processo de geração, de forma que seja possível o armazenamento de resultados intermediários. Na seção 5.3.2 é apresentada a classe Grammar, responsável por modelar a estrutura de uma gramática e implementar métodos que facilitem sua manipulação. As seções 5.3.3 e 5.3.4 apresentam,

\footnotetext{
${ }^{12}$ As tabelas utilizadas por InOutMatrix são potencialmente grandes e a maioria de suas entradas possuem valor igual a zero. Por esse motivo modelamos essas tabelas como matrizes esparsas.
} 


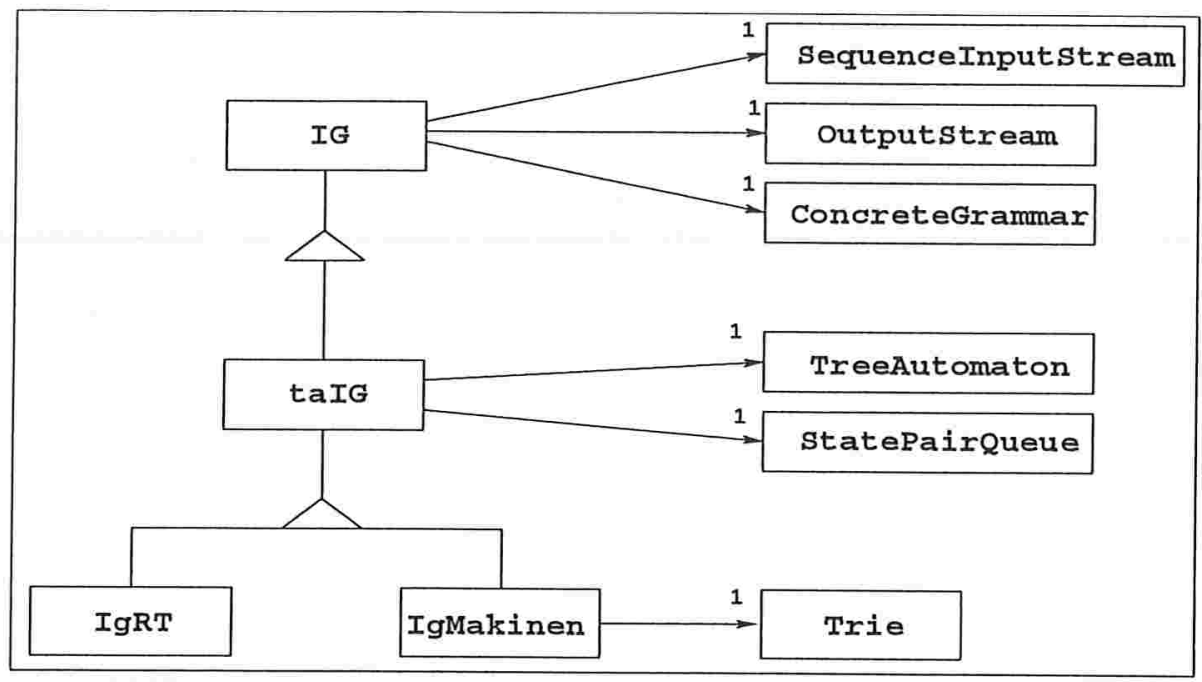

Figura 5.4: UML de IG com os componentes de suporte

respectivamente, as classes responsáveis pela modelagem das estruturas de autômato a árvore e trie, simplificando a implementação de algoritmos que utilizam estas estruturas. A seção 5.3.5 apresenta uma implementação do algoritmo de Earley. A seção 5.3.6 apresenta o GAna, componente responsável pela geração de analisadores sintáticos específicos para uma determinada gramática aprendida. A seção 5.3.7 apresenta o componente GC, responsável por agrupar as classes geradas e necessárias para gerar o classificador final.

As figuras 5.4 e 5.5 mostram como os componentes de algoritmos de aprendizado se relacionam com as classes de suporte. O IG utiliza a classe SequenceInputStream para realizar a leitura das seqüências que compõem a amostra de treinamento, infere uma gramática representada por um objeto Grammar que será armazenado em um OutputStream. Um taIG utiliza ainda a classe TreeAutomaton para manipular o autômato a árvore e a classe TAStatePairQueue para manipular a fila de pares de estados deste autômato. O EP lê as seqüências da amostra de treinamento através de SequenceInputStream, manipula a gramática de entrada como um objeto Grammar criado a partir de um GrammarInputStream e armazena a descrição da gramática estimada no OutputStream. As subclasses $E P_{F u}$ e $E P_{T G R}$ utilizam ainda classes auxiliares para manipulação de estruturas necessárias ao algoritmo, como EarleyParser e TreeAutomaton. 


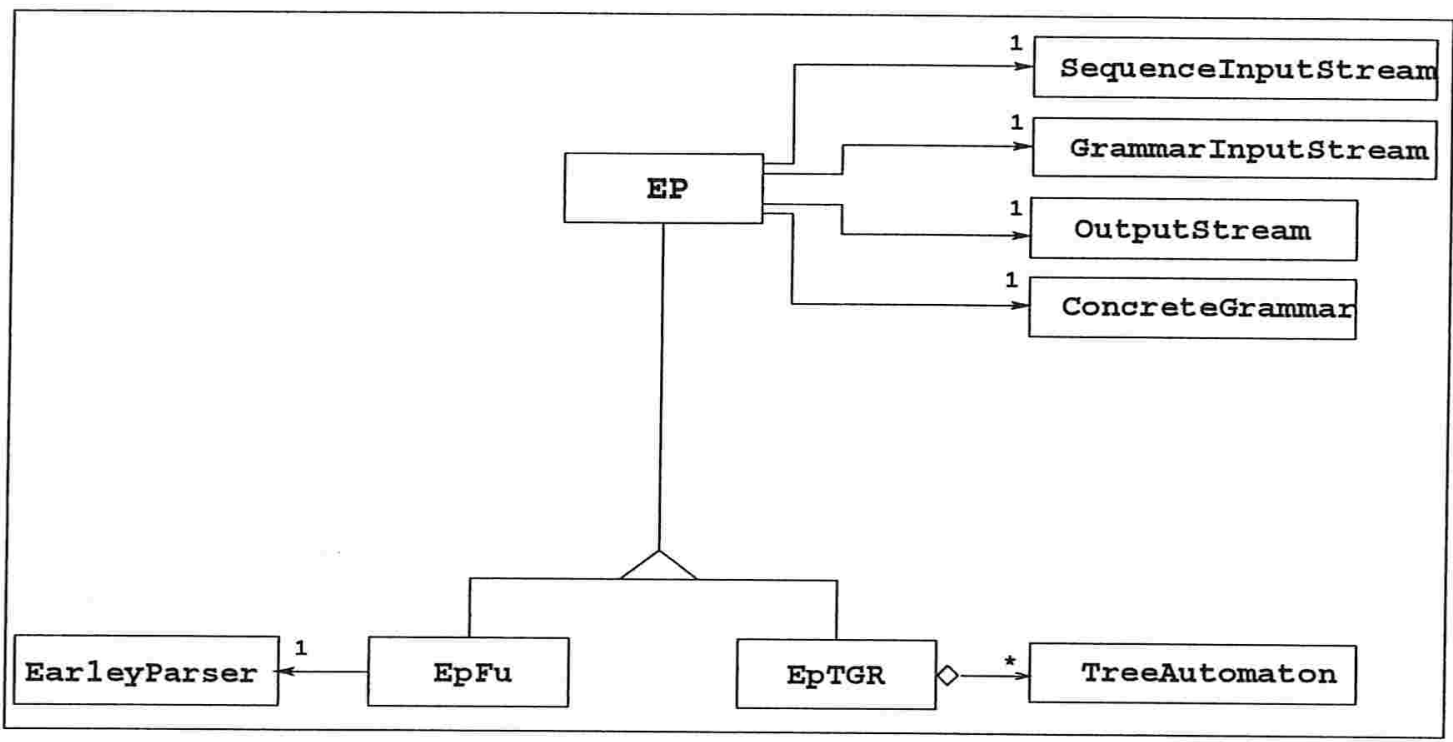

Figura 5.5: UML de EP com os componentes de suporte

\subsubsection{Streams}

Na seção anterior foi apresentada a arquitetura básica do módulo de algoritmos de aprendizado. Porém é necessário estabelecer uma comunicação entre eles que seja abstrata e permita o armazenamento de resultados intermediários. Essa comunicação não deve ser afetada pela troca de implementação dos componentes e é desejável que seja independente do formato de representação de seqüências e de gramáticas.

Para solucionar esses problemas foi projetada uma arquitetura de comunicação baseada em streams. Essa solução, inspirada na plataforma Java [Fla99], tem como objetivo fornecer uma abstração das origens, destinos, formatos e vias de comunicação entre componentes. Foram implementadas duas hierarquias de classes. Uma que implementa streams de dados de entrada, mostrada na figura 5.6, com InputStream como classe raiz. A hierarquia que implementa streams de dados de saída é mostrada na figura 5.7, com OutputStream como classe raiz. Assim cada componente deve ler dados de um InputStream e escrever dados em um OutputStream.

Um InputStream abstrai a noção de um fluxo por onde chegam os dados, possuindo métodos específicos de leitura. Diferentes tipos de streams podem conter diferentes tipos de dados, e estes podem ser obtidos de diferentes fontes. Para cada tipo de stream que se deseja manipular, basta implementar uma classe que herde de InputStream ou de uma 


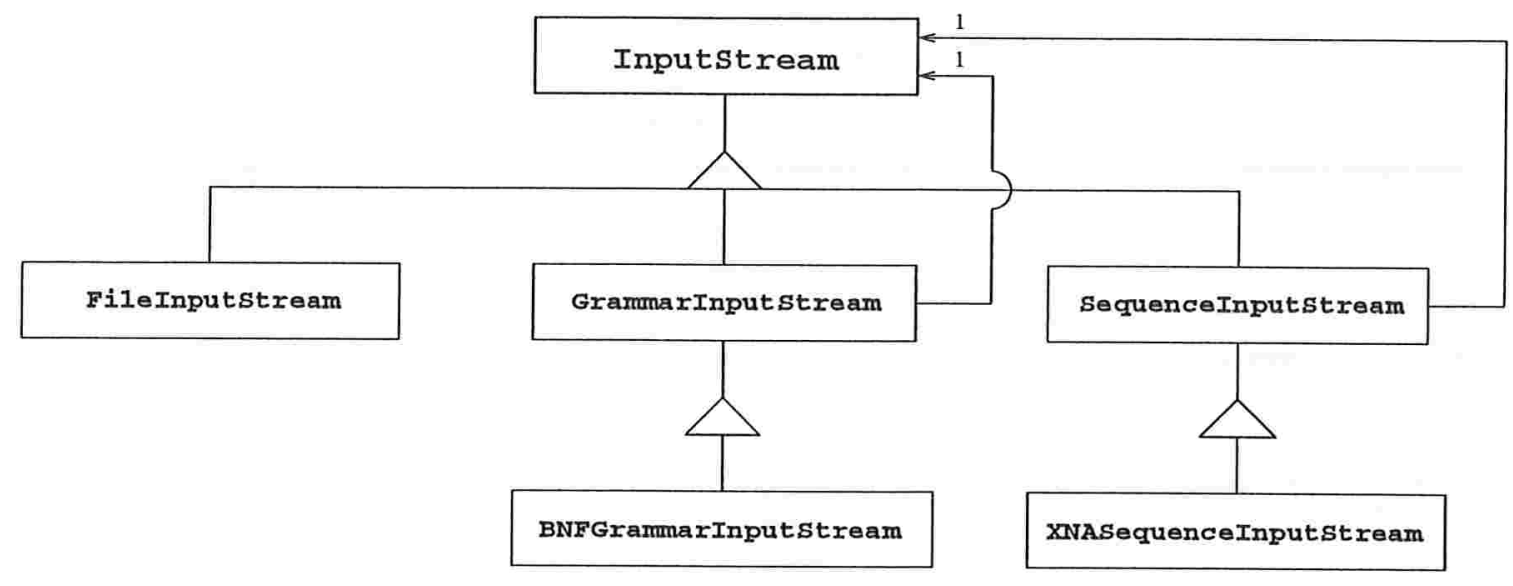

Figura 5.6: Modelagem de InputStream

de suas subclasses. Foram implementadas apenas as classes que julgamos necessárias no projeto. Classes que modelam o tipo de dado de entrada, como GrammarInputStream e SequenceInputStream, recebem como parâmetro do construtor um InputStream genérico, a fim de flexibilizar a origem dos dados.

As classes da hierarquia de dados de entrada são:

- InputStream: Trata-se de uma classe abstrata que modela um stream de dados vindos de uma fonte genérica. Suas subclasses diretas, até o momento, são FileInputStream, GrammarInputStream e SequenceInputStream.

- FileInputStream: Implementa um stream de entrada cujos dados são obtidos de um arquivo. Seu construtor deve receber como parâmetro um nome de arquivo. Um objeto dessa classe é capaz de ler diferentes tipos de dados desse arquivo, possuindo métodos de leitura de tipos inteiro, float, double, char e string. Pode também ler uma linha inteira do arquivo ${ }^{13}$.

- GrammarInputStream: Classe abstrata que modela um stream de entrada cujos dados representam uma gramática. Possui métodos específicos para leitura de produções, símbolos terminais, símbolos não terminais e probabilidade. Essas leituras, como são

\footnotetext{
${ }^{13}$ Neste caso o tamanho da linha é pré-definido em um arquivo, config.h, que possui informações configuráveis sobre o arcabouço.
} 
dependentes do formato de representação da gramática, devem ser implementadas em uma subclasse que modele um formato específico. Em nosso projeto implementamos apenas uma subclasse, que lê gramáticas em formato BNF. Para flexibilizar a fonte dessa gramática, seu construtor deve receber como parâmetro um InputStream genérico.

- BNFGrammarInputStream: Subclasse concreta de GrammarInputStream capaz de ler gramáticas em formato BNF. Seu construtor deve receber como parâmetro um objeto InputStream genérico.

- SequenceInputStream: Classe abstrata que modela um stream de entrada cujos dados são seqüências, necessitando como parâmetro do construtor um InputStream genérico que representa a fonte desses dados. As seqüências lidas por um SequenceInputStream são genéricas, ou seja, independem de um alfabeto. Esse alfabeto deve ser definido em uma subclasse. Seu construtor deve receber como parâmetro um InputStream genérico.

- XNASequenceInputStream: Essa é uma subclaśse de SequenceInputStream que define o alfabeto de seqüências de DNA e RNA. O prefixo XNA foi escolhido pelo fato de o alfabeto dessa classe conter tanto a letra $U$ quanto a letra $T$, descrevendo assim tanto seqüências de DNA quanto de RNA. Considera-se que as seqüências utilizadas neste projeto estarão em formato FASTA $^{14}$ [NCB]. Para aceitar outros formatos basta agregar os devidos métodos de leitura nesta classe. Seu construtor deve receber como parâmetro um InputStream genérico.

As classes da hierarquia de dados de saída são:

- OutputStream: Classe abstrata raiz da hierarquia de streams de saída. Trata-se de uma hierarquia mais simples, cuja única subclasse até o momento é FileOutputStream.

- FileOutputStream: Implementa um stream de dados cuja saída se dá em um arquivo. Seu construtor deve receber como parâmetro um nome do arquivo. Um objeto dessa classe é capaz de escrever vários tipos de dados nesse arquivo, possuindo métodos de escrita de tipos inteiro, float, double, char ou string. 


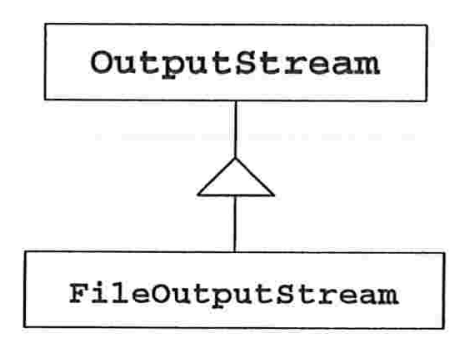

Figura 5.7: Modelagem de OutputStream

Com o uso destes streams é possível alterar os canais e os formatos dos dados que fazem a comunicação entre os componentes sem causar nenhuma mudança no código dos mesmos. Basta escolher o stream adequado, ou implementar novos de acordo com os requisitos necessários.

O canal de comunicação dos dados escolhido no momento é o arquivo. Essa decisão foi baseada por se tratar de uma solução simples e por fornecer o armazenamento em disco de resultados intermediários. Por esse motivo os únicos streams implementados que abstraem a via de armazenamento dos dados foram os FileInputStream e FileOutputStream. No entanto a arquitetura permite a implementação e utilização de outros streams como PipeInputStream e PipeOutputStream que conectam diretamente os componentes via pipeline. Também podem ser implementados BufferInputStream e BufferOutputStream, que lêem e armazenam dados em um buffer em memória.

Quanto a streams de leitura de gramáticas, a classe GrammarInputStream foi especializada através da subclasse BNFGrammarInputStream que lê gramáticas em formato BNF. Outros formatos de leitura podem ser aceitos, bastando implementar um stream que o trate e adicionando-o à hierarquia como subclasse de GrammarInputStream.

Da mesma forma, é possível criar mais especializações de SequenceInputStream. Sua classe XNASequenceInputStream lê seqüências de DNA e RNA. Para trabalhar com seqüências de proteína, basta implementar ProteinInputStream. Outras possibilidades são ainda possíveis, como um CodonInputStream que lê seqüências de DNA ou RNA e traduz para proteína. Ou ainda ReverseSequenceInputStream e ReverseSequenceOutputStream, que

\footnotetext{
${ }^{14}$ Uma descrição de seqüência no formato FASTA é iniciada com uma linha de comentário, iniciada por »", e um número arbitrário de linhas contendo a seqüência.
} 
lêem e escrevem a seqüência em seu sentido inverso correspondendo à seqüência complementar.

Na biblioteca STL não foram encontrados templates para desenvolver essa comunicação abstrata. Os templates que tratam entrada e saída (istream_iterator e ostream_iterator) realizam leituras/escritas através da entrada/saída padrão usando os operadores » e «. A proposta da coleção Stream visa fornecer uma estratégia de comunicação modular, flexível, abstrata e simples. A especialização das classes visa fornecer métodos específicos que facilitem a leitura dos dados que se deseja tratar.

\subsubsection{Grammar}

Manipular uma gramática envolve manipular uma grande quantidade de informações. Esse conjunto de informações é composto por produções (com ou sem probabilidade), símbolos terminais, símbolos não-terminais e relações entre esses elementos. A manipulação de gramáticas é necessária durante todo o processo de geração de classificadores. Torna-se necessário um componente que abstraia essas complexidades, apresentando uma interface simples.

Para esta tarefa foram implementadas as classes Grammar, ConcreteGrammar, Rule, Terminal, NonTerminal e Symbol. A relação entre essas classes pode ser vista na figura 5.8 .

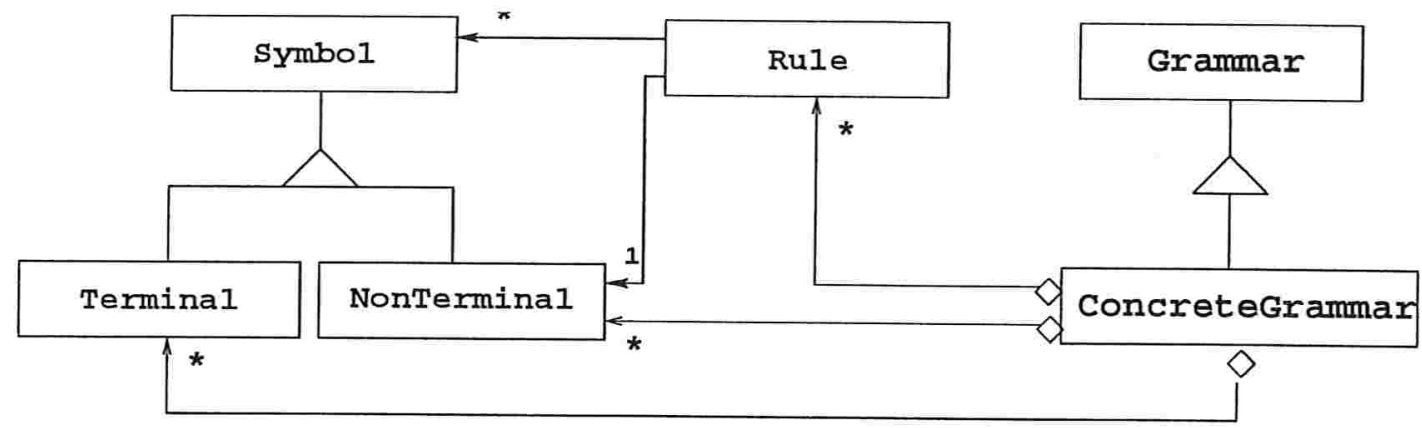

Figura 5.8: Modelagem de Grammar

Grammar é uma classe abstrata que fornece a interface mínima de uma implementação de 
gramática. ConcreteGrammar é a classe concreta que implementa uma gramática livre de contexto.

Construtores Um objeto ConcreteGrammar pode ser criado de duas formas. A primeira forma é uma criação passo a passo, utilizando o construtor ConcreteGrammar() que apenas inicializa suas estruturas, postergando a adição de símbolos e produções através de métodos específicos. Dessa forma é possível criar uma gramática adicionando seus componentes ao longo de uma aplicação. A segunda forma de criação se dá através da leitura de um GrammarInputStream que forneça a descrição de uma gramática.

Geração de classe específica Na criação a partir de um GrammarInputStream os símbolos e as produções precisam ser reconhecidos a partir da descrição da gramática contida nesse stream. Se a fonte de leitura for um arquivo, o tempo gasto com acessos ao disco pode tornar a criação da gramática muito lenta. O problema é que essa gramática precisa ser criada toda vez que seu analisador sintático for executado. Como o classificador gerado executa o analisador sintático de cada gramática para classificar uma seqüência, seu tempo de classificação é afetado diretamente pelo tempo de criação das gramáticas. No entanto, as gramáticas inferidas no processo de geração do classificador não mais serão alteradas durante a execução do mesmo. Sendo assim é possível gerar uma classe específica para cada gramática, ou seja, gerar arquivos ${ }^{15}$ de programa que definem essas classes como subclasses ${ }^{16}$ de Grammar. Para isso a classe ConcreteGrammar implementa o método generateSpecificGrammar que recebe como parâmetros o nome da classe a ser gerada e o diretório onde seus arquivos estarão contidos. Dessa forma um analisador sintático pode instanciar diretamente a classe gerada de sua gramática, agilizando seu tempo de execução. Não apenas a criação da gramática torna-se mais rápida como também sua execução, uma vez que muitas estruturas estarão alocadas estaticamente. Como cada gramática tem sua classe, seus métodos podem tirar vantagens de informações já conhecidas, como listas de símbolos e de produções, símbolo inicial, etc.

Iteradores Para facilitar a manipulação de símbolos e produções, a classe Grammar dispõe de métodos que retornam iteradores para enumerar esses conjuntos. Um iterador é uma

\footnotetext{
${ }^{15}$ Como o arcabouço é implementado em $\mathrm{C}++$, estes arquivos consistem de um arquivo .cpp e um .h.

${ }^{16} \mathrm{~A}$ classe Grammar define uma interface composta apenas por métodos de consulta e impressão, não possuindo métodos de alteração.
} 
implementação do padrão Iterator de orientação a objetos [GHJV99]. Sua função é fornecer uma forma de acesso seqüencial a uma coleção de objetos, sem revelar como essa coleção está implementada internamente. Dessa forma uma coleção de símbolos ou produções pode ser manipulada através de um iterador sem nenhuma dependência da forma como eles estão armazenados: lista ligada, lista seqüencial, hash, etc. Essa abordagem fornece, além de simplicidade na manipulação dessas coleções, flexibilidade para mudanças na implementação das mesmas.

A classe Grammar possui métodos que retornam iteradores para o seguintes conjuntos:

- conjunto de terminais;

- conjunto de não terminais;

- conjunto de produções;

- conjunto de produções com um determinado símbolo no lado direito;

- conjunto de produções com um determinado símbolo no lado esquerdo.

Impressão A classe Grammar possui métodos de impressão. O método implementado, printBNF, imprime a gramática no formato BNF. No entanto, outros métodos podem ser implementados para impresssão em outros formatos. Esses métodos imprimem a gramática em um OutputStream especificado como parâmetro.

Manipulação das probabilidades Uma gramática pode ser estocática ou não. No caso de ser estocástica, a soma das probabilidades das produções com o mesmo lado esquerdo deve ser igual a 1. Durante um processo de estimação de probabilidades, várias alterações são feitas nos valores de probabilidades, e seria custoso manter essa propriedade a cada alteração realizada. Para facilitar esse processo a classe ConcreteGrammar implementa o método normalizeProbabilities que normaliza os valores atribuídos à probabilidade de cada produção de forma a respeitar as propriedades de uma gramática estocástica. Dessa forma, pode-se atribuir qualquer valor à probabilidade de uma produção (inclusive valores maiores que 1) e, ao final das alterações, invocar o método normalizeProbabilities.

É possível também inicializar as probabilidades da gramática de forma que todas as produções com o mesmo não terminal do lado esquerdo possuam a mesma probabilidade. Isso é feito através do método initializeUniformProbabilities. 
Extensões futuras Extensões na classe ConcreteGrammar também podem ser feitas. Embora essa classe manipule gramáticas livres de contexto, e portanto qualquer gramática que pertença a uma classe abaixo na hierarquia de Chomsky, pode-se definir também algumas classes específicas como RegularGrammar, LinearGrammar, ReversibleGrammar, e quantas outras forem necessárias. Algumas dessas gramáticas são caracterizadas por propriedades que envolvem todo o conjunto de produções. É o caso de ReversibleGrammar, cuja definição foi vista na seção 3.3.3. Elas poderiam ser implementadas de forma que, no momento de sua criação ou inserção de produções, as propriedades das produções sejam verificados automaticamente.

\subsubsection{TreeAutomaton}

Os dois algoritmos de inferência escolhidos para serem implementados utilizam um autômato a árvore definido em [LJ78] para manipular exemplos estruturais. Essa estrutura pode ser também utilizada por outros algoritmos que manipulam gramáticas baseadas em árvores ou exemplos estruturais [Sak90, SF00, Mäk98]. Por esse motivo essa estrutura foi implementada separadamente e disponibilizada no módulo auxiliar.

A implementação de autômato a árvore é composta pelas classes TreeAutomaton, TANode, TALeaf, TAState e TABlock, cuja UML pode ser vista na figura 5.9.

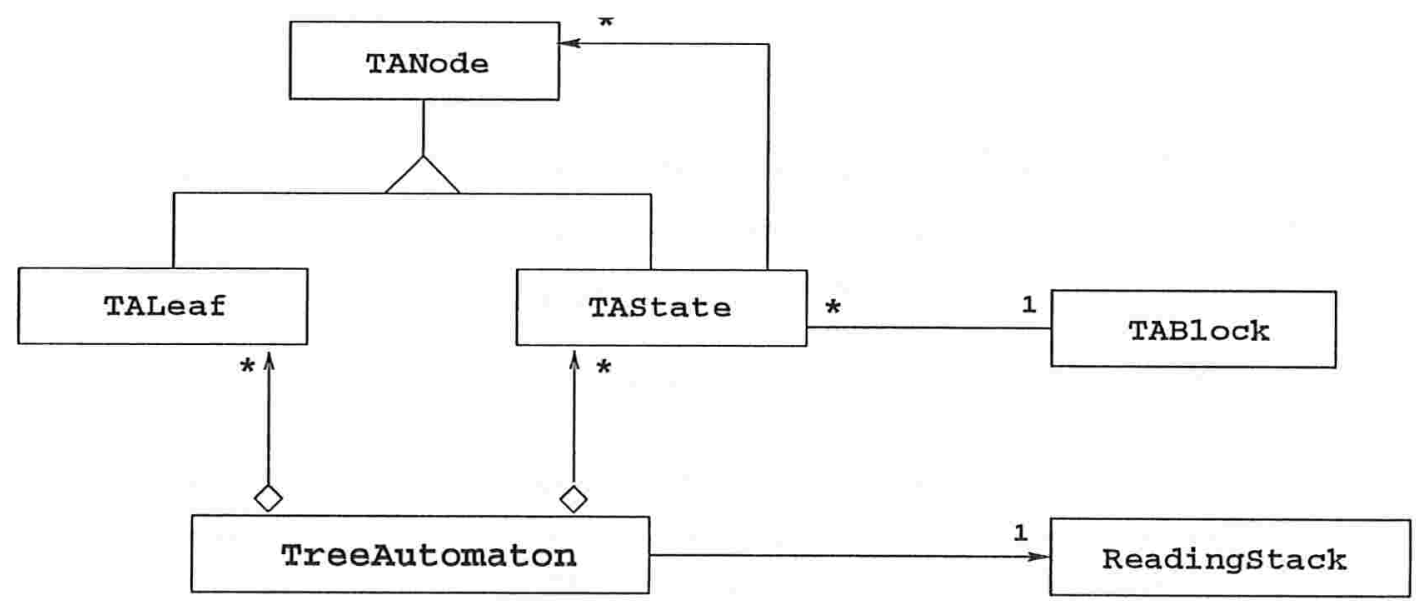

Figura 5.9: UML simplificada de TreeAutomaton 
O autômato é criado a partir de seqüências parentisadas ${ }^{17}$. Inicialmente o autômato possui uma árvore para cada seqüência. Essa operação é realizada pelo método createOneTree, que obtém as seqüências de um SequenceInputStream.

Conforme apresentado no capítulo 3 , todo autômato a árvore corresponde a uma gramática livre de contexto. Essa equivalência é definida por três mapeamentos:

1. Cada estado corresponde a uma produção: o estado representa o lado esquerdo de uma produção, enquanto seus descendentes representam o lado direito dessa produção.

2. Cada bloco corresponde a um símbolo não terminal da gramática. Ou seja, cada estado é representado na gramática pelo bloco ao qual pertence.

3. Cada folha corresponde a um símbolo terminal da gramática.

A classe TreeAutomaton, através do método generateGrammar, gera a gramática correspondente ao autômato a árvore, retornando um objeto Grammar.

Note que, como cada nó descendente de um estado pode ser uma folha ou um outro estado, uma superclasse TANode foi criada fornecendo uma interface comum a eles. Essa estratégia de implementação é uma aplicação do padrão Composite ${ }^{18}$.

Assim como a classe Grammar, a classe TreeAutomaton fornece iteradores que enumeram as coleções de estados e estados finais (estados raízes de cada árvore). Fornece também um iterador que enumera todos os estados cujo conjunto de descendentes é formado apenas por folhas ${ }^{19}$.

Nos dois algoritmos inferidores implementados, o inferidor processa pares de estados do autômato a árvore. Por esse motivo foi também implementada uma abstração de uma fila de pares de estados através da classe TAStatePairQueue.

\footnotetext{
${ }^{17}$ Compare a parentisação da frase exemplificada na seção 3.3 .2 e a figura 3.1 de sua reprentação equivalente.

${ }^{18}$ Composite é um padrão de desenho orientado a objetos no qual o objetivo é compor objetos em estruturas de árvores representando hierarquias "parte-todo". Esse padrão visa permitir o tratamento de objetos individuais e composições de objetos de maneira uniforme [GHJV99].

${ }^{19}$ Este iterador é usado pelo componente IgMakinen, que trata separadamente produções de uma gramática cujo lado direito é composto apenas por símbolos terminais, que no autômato a árvore são equivalentes a estados cujos descendentes são apenas folhas.
} 


\subsubsection{Trie}

Uma trie é uma estrutura de dados utilizada pelo algoritmo de inferência gramatical desenvolvido por Makinen [Mak92], um dos escolhidos para implementação. No mesmo trabalho em que apresenta seu algoritmo, Makinen aborda a possibilidade de aplicação de tries em outros algoritmos de inferência, descrevendo como o algoritmo RT de Sakakibara ${ }^{20}$ poderia ser implementado utilizando tries. Por esse motivo a classe Trie foi adicionada ao módulo auxiliar, a fim de facilitar a exploração da utilização dessa estrutura em novos algoritmos.

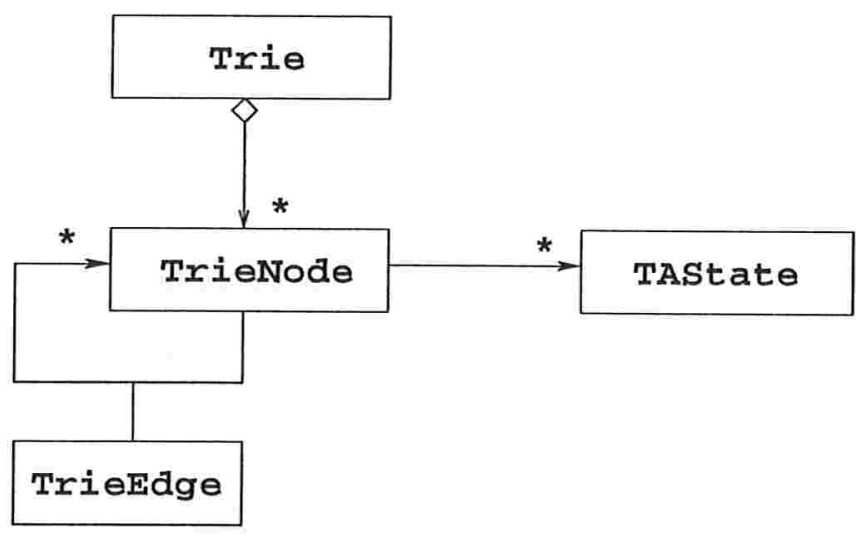

Figura 5.10: Classes envolvidas na modelagem de Trie

A implementação da estrutura trie, decrita em 3.4.2, é composta pelas classes Trie, TrieNode e TrieEdge, cuja modelagem pode ser vista na figura 5.10.

A classe Trie fornece métodos para inserção de arestas, inserção de nós e associação de objetos a nós. Fornece também, através do método getNodesIterator, um iterador para os nós de uma trie.

\subsubsection{EarleyParser}

Dadas uma gramática e uma seqüência, esta seqüência pode ser reconhecida ou não pela gramática. Se for reconhecida, pode haver uma ou mais árvores sintáticas que descrevem

\footnotetext{
${ }^{20} \mathrm{O}$ algoritmo RT é o outro algoritmo implementado neste trabalho, mas sem o uso de tries.
} 
suas derivações. Implementar um analisador de forma a obter essas árvores é mais trabalhoso do que simplesmente saber se a seqüência é reconhecida ou não. Porém, dos componentes implementados, dois deles necessitam obter essas informações: o gerador de analisadores sintáticos e um dos estimadores de probabilidades.

Nossos analisadores sintáticos lidam com gramáticas estocásticas. Portanto, ao analisarem uma seqüência, devem fornecer a probabilidade dessa seqüência segundo a gramática considerada. Para isso o analisador precisa identificar quais são as produções utilizadas na análise da seqüência, e quantas vezes cada uma delas foi utilizada. A probabilidade de uma seqüência é a soma das probabilidades de suas árvores sintáticas, caso exista mais de uma. A probabilidade de cada árvore sintática é o produto das probabilidades das produções que compõem essa árvore.

O estimador de probabilidades de gramáticas descrito em [Fu82] também necessita da informação de todas as árvores sintáticas das seqüências analisadas. A estimação das probabilidades das produções é baseada no número de vezes que cada produção é utilizada durante a análise das seqüências contidas na amostra de treinamento.

O algoritmo de Earley [Ear70] é um analisador sintático para gramáticas livres de contexto capaz de fornecer todas as árvores sintáticas de uma seqüência, caso exista mais de uma. Porém a forma com que um analisador sintático estocástico processa as produções dessa árvore difere do processamento feito pelo estimador. Era necessário implementar o algoritmo de Earley atendendo os dois componentes: o gerador de analisadores e o estimador de probabilidades. Por isso o algoritmo de Earley ${ }^{21}$ foi encapsulado em um componente auxiliar chamado Earley Parser.

Um objeto EarleyParser está associado a uma gramática. Na chamada do método que executa a análise sintática são passados como parâmetro uma seqüência a ser analisada e um algoritmo (instância da classe ParserTask). Esse algoritmo será executado toda vez que uma árvore sintática da seqüência for reconhecida. Isso permite seu uso tanto pelo estimador de probabilidades quanto pelo analisador estocástico. Para estimar as probabilidades é usado o algoritmo definido na classe RuleFrequenceCounter. Para calcular a probabilidade de uma seqüência é usado o algoritmo definido na classe ProbabilityCalculation.

Essa técnica de parametrizar o algoritmo a ser executado sobre as árvores sintáticas é

\footnotetext{
${ }^{21}$ Omitimos maiores informações sobre o algoritmo de Earley por julgarmos fora do escopo de nosso trabalho. Uma descrição detalhada do algoritmo pode ser encontrada em [Ear70].
} 


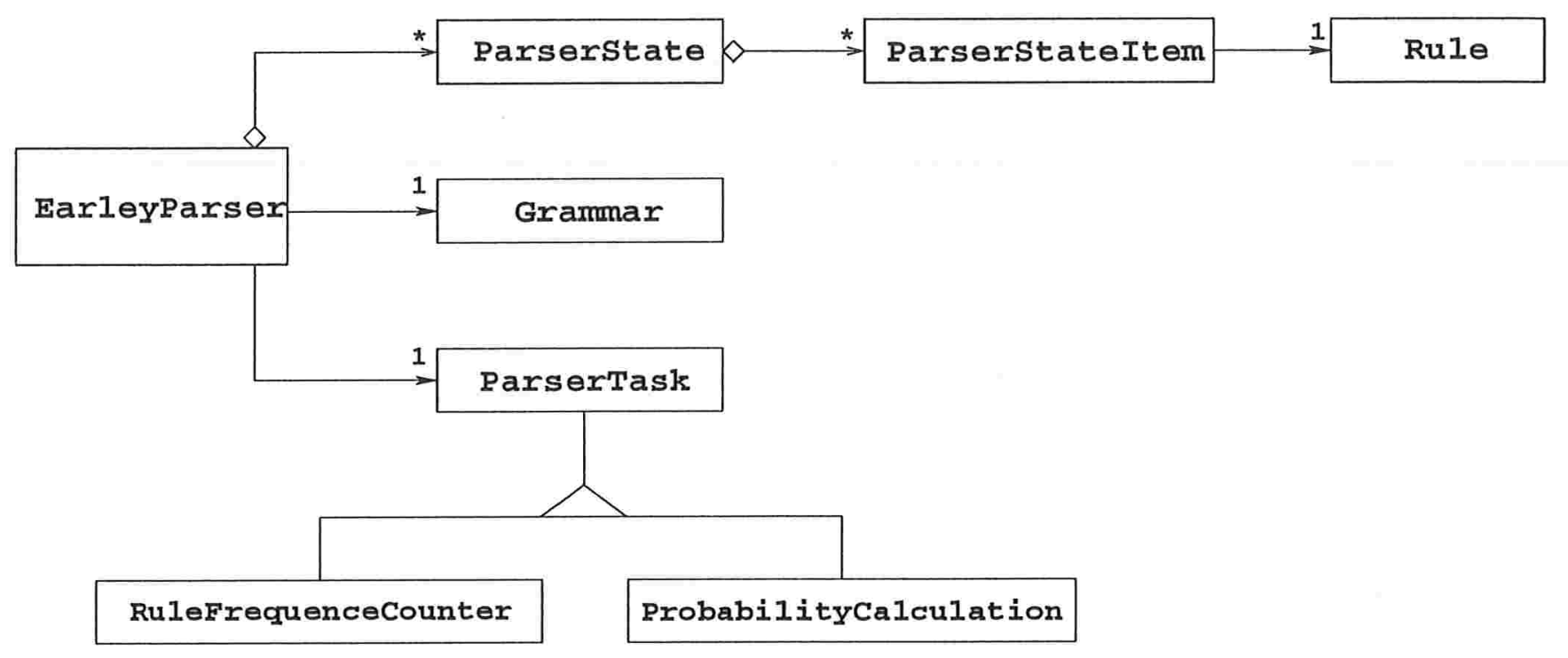

Figura 5.11: UML simplificada de EarleyParser

uma aplicação do padrão de desenho orientado a objetos Strategy. Esse padrão define um conjunto de algoritmos que possam ser intercambiáveis em uma aplicação [GHJV99].

Este componente é composto pelas classes EarleyParser, ParserState, ParserStateItem e Algorithm, como mostra a figura 5.11.

\subsubsection{Gerador de Analisadores Sintáticos (GAna)}

Conforme apresentado na seção 5.3.2, a partir da descrição de uma gramática é gerada uma classe $\mathrm{C}++$ que implementa especificamente essa gramática. Desta forma a gramática é alocada estaticamente, minimizando riscos de vazamentos de memória e acesso a posições inválidas, e melhorando o tempo de manipulação de suas estruturas. O tempo de criação da gramática também é menor, já que não será mais necessária sua leitura a partir de um arquivo. No entanto, como se trata de uma classe específica, é necessário gerar um analisador específico para essa gramática gerada.

O componente GAna é um gerador de analisadores sintáticos para gramáticas livres de contexto. Ele recebe como parâmetros um GrammarInputStream contendo a descrição de uma gramática, um nome a ser dado à classe específica da gramática e um diretório destino dos arquivos gerados. O GAna gera como saída, no diretório especificado, os arquivos da 
classe da gramática descrita no GrammarInputStream.

Por exemplo, para gerar as classes da gramática a partir de um objeto gis da classe GrammarInputStream, basta fazer

GAna* gerador $=$ new GAnaEarley (gis, "GramExemplo", "\\$HOME/classificadores"); gerador->generate ();

que produz no diretório "\$HOME/classificadores" os arquivos que definem a classe "GramExemplo":

GramExemplo.h

GramExemplo.cpp

Para implementar o analisador sintático utilizamos o algoritmo de Earley [Ear70], por se tratar de um algoritmo geral. Ele é capaz de analisar qualquer gramática livre de contexto, mesmo que ambígüa. Porém essa generalidade torna-o lento. Algoritmos mais eficientes podem ser implementados quando tratarem de classes de gramáticas mais restritas, como regulares e LALR. Assim outros geradores de analisadores podem ser implementados.

Para possibilitar essas novas implementações, a classe GAna foi implementada como uma classe abstrata, capaz de gerar os arquivos da gramática específica. O analisador sintático, porém, deve ser criado por uma subclasse. No momento, temos uma subclasse, a GAnaEarley, que utiliza um analisador de Earley.

As classes envolvidas neste componente são mostradas na figura 5.12.

\subsubsection{Gerador de Classificadores (GC)}

Um classificador pode ser gerado a partir de uma ou várias famílias de seqüências. Ou seja, um classificador pode ser composto de uma ou várias gramáticas aprendidas durante a fase de geração. É necessário gerar um analisador sintático para cada uma delas, gerar um programa que os utilize e agrupar todos esses arquivos.

O Gerador de Classificadores (GC) é o componente responsável por essas tarefas. Ele recebe como entrada um nome para o classificador, o diretório onde estão localizados os arquivos gerados pelo Gana e os nomes das gramáticas consideradas no processo de geração. Como saída, gera um arquivo .cpp com o nome especificado para o classificador e um Makefile. 


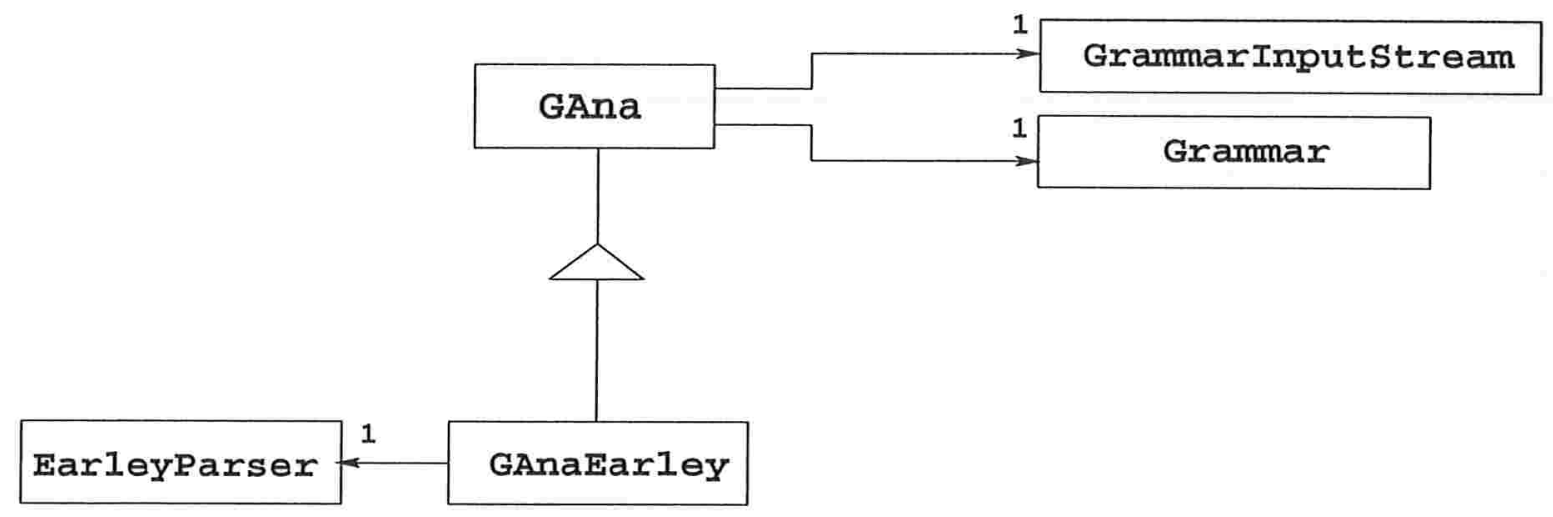

Figura 5.12: Classes do componente GAna

O arquivo .cpp implementa o programa classificador propriamente dito. Este recebe como parâmetros um SequenceInputStream contendo um conjunto de seqüências a serem analisadas e os nomes das gramáticas geradas pelo Gana. Ele utiliza os analisadores gerados a partir dessas gramáticas para obter a probabilidade de cada seqüência de entrada segundo essas gramáticas. Gera como saída um OutputStream com a classificação dessas seqüências.

O Makefile gerado será utilizado para compilar e agrupar os arquivos gerados das gramáticas aprendidas, dos analisadores sintáticos e do programa classificador. Ele gera o programa executável do classificador com o nome especificado na chamada do GC.

\subsection{Módulo de suporte à composição e testes dos algo- ritmos}

No capítulo 6 é apresentada a metodologia de testes dos classificadores, segundo a qual testaremos classificadores gerados a partir de amostras de treinamento de diferentes tamanhos. Como serão usados dados simulados, essas amostras devem ser geradas pelo GS. Desta forma, para gerar e testar um classificador, é necessário seguir uma série de passos:

- gerar as amostras de diferentes tamanhos;

- utilizar essas amostras como entrada de um inferidor para obter as gramáticas não 
estocásticas;

- utilizar as amostras de treinamento e as gramáticas inferidas como entradas do estimador, obtendo as gramáticas não estocásticas;

- gerar analisadores sintáticos para essas gramáticas;

- gerar os classificadores finais;

- gerar as amostras de teste positivas e negativas;

- classificar as seqüncias das amostas de teste;

- documentar os resultados obtidos.

Ou seja, mesmo com todos os algoritmos já implementados, a fase de testes iria requerer um certo tempo de realização de trabalho repetitivo. Além disso, a necessidade de conhecer todos os passos necessários para a realização dos testes e parâmetros de cada um aumenta a possibilidade de erros durante a geração. Para livrar o usuário do aracabouço de detalhes estruturais e automatizar a execução de tarefas, foi desenvolvịdo um programa que, recebendo uma parametrização adequada, realiza todas essas tarefas em forma de um pipeline.

Esse programa é composto por um conjunto de programas mais simples, escritos em Perl e em $\mathrm{C}++$, que podem ser utilizados separadamente. Entre eles estão programas que lidam com arquivos de seqüências no formato FASTA. Suas tarefas são:

- contagem do número de seqüências contidas no arquivo;

- remoção de seqüências repetidas;

- filtragem de seqüências presentes em um segundo arquivo;

- remoção de parentisação das seqüências;

- conversão de um conjunto de seqüencias para o formato FASTA;

- extração de um subconjunto de determinado tamanho de um conjunto de seqüências;

- filtragem de seqüências que estejam em um determinado intervalo de tamanho;

- geração de amostras de treinamento; 
- geração de amostras de teste positivas;

- geração de amostras de teste negativas.

Outros programas foram desenvolvidos com o intuito de facilitar a obtenção dos resultados dos testes, realizando as seguintes tarefas:

- obtenção do número de seqüências reconhecidas por um classificador;

- contagem do número de produções de um arquivo que contém a descrição de uma gramática $^{22}$

- cálculo do erro médio relativo das probabilidades atribuídas a uma amostra de teste;

- cálculo da porcentagem de falsos positivos ou falsos negativos de um teste;

- cálculo da média de resultados obtidos de uma repetição de testes ${ }^{23}$.

O programa diretamente associado com o processo de geração dos classificadores e testes possui parâmetros para obter a gramática alvo, o tamanho mínimo da amostra desejado, tamanho máximo e intervalo dos tamanhos de amostra utilizados no teste, intervalo de tamanho de seqüências negativas a serem geradas, quantas vezes os testes devem ser repetidos utilizando diferentes amostras de mesmo tamanho e quais os algoritmos que serão utilizados no processo de geração dos classificadores. Com essas informações ele utiliza os programas citados nesta seção para gerar as amostras, gerar os classificadores, aplicar os testes, e recolher os resultados e armazená-los em um formato que facilite análises estatísticas no Matlab. Dessa forma, a realização de um teste leva apenas alguns minutos, ou seja, uma vez que os algoritmos estejam implementados e inseridos nos diretórios esperados e fornecida a descrição da gramática estocástica alvo no formato aceito pelo GS, é gasto apenas o tempo de escolher os parâmetros do programa gerador.

\footnotetext{
${ }^{22}$ Essa informação foi utilizada para comparar o número de produções das gramáticas inferidas com o número de produções da gramática original.

${ }^{23}$ No capítulo 6 é apresentada a metodologia de testes, através da qual os testes foram realizados sobre classificadores gerados repetidas vezes com diferentes amostras de mesmo tamanho.
} 
$\therefore$ 


\section{Avaliação preliminar dos algoritmos}

Uma vez implementados os algoritmos de aprendizado gramatical, torna-se possível a geração de classificadores a serem utilizados na classificação de seqüências. No entanto, é preciso pesquisar a aplicabilidade desses algoritmos no contexto biológico onde temos amostras limitadas. O arcabouço foi criado com o intuito de promover um laboratório para a realização dessas pesquisas. Por esse motivo foi introduzido nesse trabalho uma avaliação preliminar dos algoritmos implementados, a fim de verificar como esses algoritmos se comportam em casos controlados, ou seja, na identificação de gramáticas livres de contexto conhecidas que modelem seqüências biológicas.

Conforme visto na seção 3.1, identificação no limite é um critério de parada de modelos de inferência indutiva. Os dois algoritmos inferidores selecionados para implementação lidam com classes de gramáticas que podem ser identificadas no limite utilizando exemplos estruturais [Sak95]. Isto quer dizer que a identificação da gramática alvo pode ser realizada a partir de um tamanho de amostra finito. O objetivo dos testes é, portanto, verificar como se comporta o processo de aprendizado das gramáticas inferidas pelos algoritmos implementados.

O objetivo desses testes não é apenas constatar a convergência das gramáticas inferidas pelos algoritmos utilizados, mas avaliar esse processo. No meio biológico dispõe-se geralmente de um pequeno número seqüências que sirvam de exemplo de uma determinada família. É necessário então saber qual o tamanho típico de amostras com o qual um algoritmo de inferência ou estimação consegue convergir, ou se ele consegue obter uma boa aproximação com amostras de tamanhos menores. Para isso deve-se avaliar também como se comporta esse processo antes do ponto de convergência. Essa avaliação permite verificar a aplicabilidade desses algoritmos no aprendizado de famílias de seqüências biológicas. 
A fim de observar o comportamento dos algoritmos, estes foram utilizados no aprendizado de seis gramáticas. Para cada gramática foram gerados vários classificadores a partir de amostras de diferentes tamanhos. A metodologia usada na geração de amostras e procedimento dos testes é descrita na seção 6.1. Na seção 6.2 são apresentadas as gramáticas utilizadas nos testes. Duas gramáticas puderam ser identificadas com sucesso, permitindo a realização de todos os testes propostos na seção 6.1. Outras, no entanto, ofereceram problemas durante o processo de identificação ou de testes. A exploração desses problemas é importante para delimitar o escopo da aplicabilidade dos algoritmos implementados, ressaltando pontos fracos que podem ser alvo de melhoria.

Nas seções 6.3 e 6.4 são apresentadas as análises dos resultados dos algoritmos de inferência e de estimação, respectivamente.

\subsection{Metodologia de testes}

\subsubsection{Informações avaliadas}

Para avaliar os algoritmos inferidores, foram obtidos os resultados de reconhecimento das seqüências de teste pela gramática inferida. Os classificadores gerados nesta fase são binários, isto é, consideram apenas uma gramática e classificam uma seqüência como pertencente ou não à família representada. O processo de aprendizado de uma gramática é um mecanismo de generalização das seqüências utilizadas no treinamento. Por esse motivo, os erros de reconhecimento que esse classificador pode cometer foram separados em dois tipo: falsos positivos e falsos negativos ${ }^{1}$. A taxa de falsos negativos revela se o processo de aprendizado realizou uma generalização, ou seja, se a gramática inferida é capaz de reconhecer outras seqüências não utilizadas no treinamento. A taxa de falsos positivos revela se esse generalização não foi excessiva, ou seja, se a gramática inferida reconhece também muitas seqüências que não pertencem à família que visa caracterizar. Para medir essas taxas foram utilizados dois tipos de amostras de testes: uma positiva ${ }^{2}$ (com seqüências pertencentes à

\footnotetext{
${ }^{1}$ Um erro é do tipo falso positivo quando uma seqüência que não pertence à família considerada é classificada como pertencente. Um erro é do tipo falso negativo quando uma sequiência que pertence à família considerada é classificada como não pertencente.

${ }^{2}$ Para verificar o poder de generalização dos algoritmos inferidores, foi estabelecido que a amostra de teste positiva não devia conter seqüências utilizadas no treinamento.
} 
família considerada) e outra negativa (com seqüências não pertencentes à família).

Outro dado obtido foi o número de produções das gramáticas inferidas, a fim de observar a oscilação do tamanho das gramáticas inferidas durante o processo de inferência, visando avaliar o processo de convergência das mesmas.

As seqüências que são corretamente reconhecidas pelo classificador estão associadas a uma probabilidade que é dada pela gramática aprendida, enquanto seqüências não reconhecidas recebem probabilidade igual a 0 . Para avaliar os algoritmos estimadores, foi verificado o quanto essa probabilidade se aproxima da probabilidade dada pela gramática original. Para isso calculou-se o erro médio relativo das probabilidades das seqüências reconhecidas pelo classificador. Tal erro é dado por

$$
\left(\sum_{i=1}^{n} \frac{\left|\hat{P}_{i}-P_{i}\right|}{P_{i}}\right) / n
$$

onde $\hat{P}_{i}$ é a probabilidade estimada da seqüência $i$ (dada pela gramática aprendida), $P_{i}$ é a probabilidade real da seqüência $i$ (dada pela gramática original), e $n$ é o número de seqüências reconhecidas em uma determinada amostra de teste. Esse cálculo foi efetuado para cada. classificador treinado com as amostras de diferentes tamanhos. Esses resultados forneceram uma terceira curva que nos permitiu verificar a qualidade do processo de estimação de probabilidades da gramática.

\subsubsection{Utilização de dados simulados}

Para a obtenção dos resultados de falsos negativos e falsos positivos dos classificadores, utilizamos nos testes seqüências que seguramente se sabe se pertencem ou não à família considerada. Também é importante dispor de um grande número de seqüências para compor as amostras de treinamento, pois não se sabe a priori qual o tamanho de amostra mínimo necessário para que ocorra a convergência das gramáticas inferidas. Outra vantagem de possuir um grande número de seqüências de treinamento durante a fase de testes é a possibilidade de repetição dos testes com amostras de mesmo tamanho porém compostas por diferentes seqüências. Isso permite resultados de testes mais independentes das amostras utilizadas. A repetição dos testes com várias amostras diminui a possibilidade de uma avaliação errônea por culpa do uso de amostra muito boa (bastante característica) ou muito ruim (pouco característica). 
Para dispor de amostras com essas características, foram utilizados no teste dados simulados, ou seja, seqüências geradas a partir de uma gramática estocástica conhecida. Isso permite conhecer previamente a classificação correta de cada seqüência utilizada no teste. Para gerar essas seqüências foi integrado ao sistema um módulo desenvolvido por Caetano Jimenez Carezzato, o gerador de seqüências ${ }^{3}$ (GS). O uso desse módulo também possibilita gerar um número de seqüências de treinamento limitado apenas pelo tamanho da linguagem gerada pela gramática utilizada pelo gerador.

A figura 6.1 mostra como o GS foi integrado à arquitetura, e como ela foi usada para gerar quatro modelos de classificadores a partir da configuração dos dois algoritmos implementados para o módulo IG e dos dois algoritmos implementados para o módulo EP.

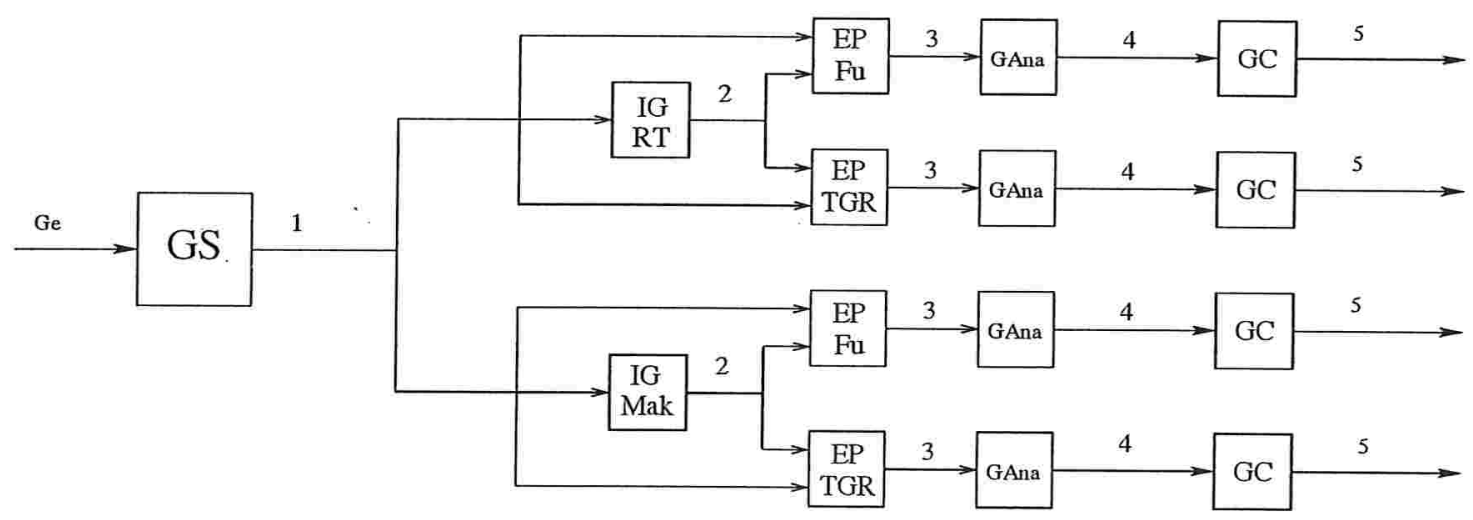

Figura 6.1: Quatro modelos de classificadores

O procedimento de testes foi composto pelos seguintes passos:

1. Geração das amostras de treinamento e de testes.

2. Inferência das gramáticas não estocásticas pelos módulos $I G_{R T}$ e $I G_{\text {Makinen }}$.

3. Para cada gramática inferida no passo anterior, geração de duas gramáticas estocásticas a partir da estimação das probabilidades pelos algoritmos $E P_{F u}$ e $E P_{T G R}$.

\footnotetext{
${ }^{3}$ Esse módulo tem como objetivo ser uma fonte de dados simulados. Ele recebe como entrada um arquivo contendo a descrição de uma gramática estocática. Utilizando métodos probabilísticos, gera como saída um arquivo contendo um conjunto de seqüências geradas a partir dessa gramática.
} 
4. Geração dos analisadores sintáticos e classificadores a partir das gramáticas estocásticas geradas no passo anterior.

5. Classificação das seqüências das amostras de teste utilizando os classificadores gerados.

6. Desenho e análise das curvas de erro.

\subsubsection{Escolha das gramáticas}

Como os testes tratam de algoritmos que lidam com gramáticas livres de contexto estocásticas, foram pesquisadas gramáticas que modelassem a estrutura secundária de RNAs, que podem ser ser descritas por GLCEs.

Foram encontradas duas gramáticas livres de contexto para RNAs. Uma delas, que será chamada $G_{S a k}$, é uma gramática pequena (18 produções) usada por Sakakibara em seus trabalhos $\left[\mathrm{SBU}^{+} 93, \mathrm{Mic} 93, \mathrm{SBU}^{+} 94, \mathrm{SBH}^{+}\right.$94a, $\mathrm{SBH}^{+}$94b] para demonstrar que algumas estruturas biológicas podem ser descritas por GLCEs. A outra gramática, que será chamada $G_{t R N A}$, é uma gramática maior (660 produções) criada por Sakakibara [SBU ${ }^{+}$93] para testar seu algoritmo reestimador de gramáticas a árvores na modelagem de RNAs transportadores.

Os resultados dos testes envolvendo essas duas gramáticas foram muito díspares. Enquanto os algoritmos convergiram rapidamente nos testes com $G_{S a k}$, eles não conseguiram convergir nos testes com a $G_{t R N A}$. Utilizando seqüências de $G_{t R N A}$, o inferidor $I G_{R T}$ inferiu gramáticas cada vez maiores, chegando a inferir uma gramática de 108838 produções sem convergir. Além disso, não foi possível realizar a análise sintática dessa gramática utilizando o algoritmo de Earley ${ }^{4}$. Isso impossibilitou a geração de amostras negativas de $G_{t R N A}{ }^{5}$, e conseqüentemente de realizar os testes de falsos positivos.

Por esses motivos foram criadas quatro novas gramáticas: $G_{\text {codingRegion }}, G_{\text {stem-loop }}, G_{\text {branch }}$ e $G_{n o-r e v e r s i b l e}$.

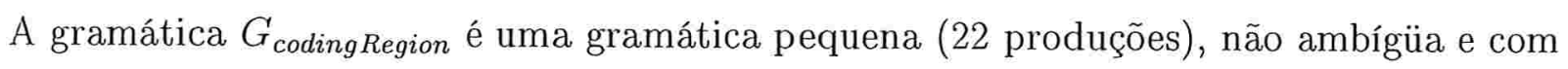

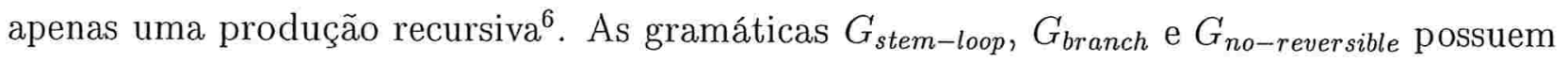
um número pequeno de produções (9 a 12 produções) como na $G_{S a k}$, mas possuem muitas

\footnotetext{
${ }^{4} \mathrm{~A}$ execução deste algoritmo foi cancelada após dois dias analisando uma sequiência para esta gramática.

${ }^{5}$ Para gerar amostras negativas de uma gramática $G$, foram geradas sequiências genéricas sobre o alfabeto a, c, g, u e filtradas aquelas que são reconhecidas por $\mathrm{G}$.

${ }^{6}$ Uma produção recursiva é uma produção onde o símbolo não terminal do lado esquerdo está também presente no lado direito.
} 
produções com o mesmo lado esquerdo, como em $G_{t R N A}$. A $G_{\text {stem-loop }}$ é uma gramática não

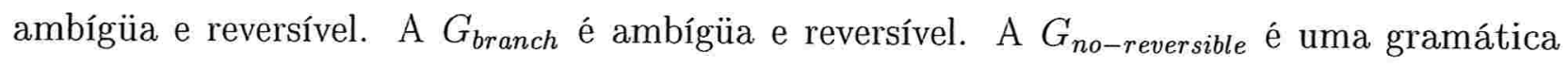
ambígüa equivalente a $G_{b r a n c h}$, porém não reversível. O objetivo foi testar se a ambigüidade era o fator de demora na execução do analisador de Earley e se a reversibilidade ou não da gramática influenciava o inferidor $I G_{R T}$.

A execução do analisador de Earley ofereceu novamente o problema de tempo de execução para as gramáticas $G_{\text {stem-loop }}, G_{b r a n c h}$ e $G_{n o-r e v e r s i b l e}$, não sendo possível realizar os testes de falsos positivos. $\grave{A}$ medida que as gramáticas inferidas se aproximavam da gramática original, também não era possível executar o analisador para elas, impedindo a realização também dos testes de falsos negativos. A aplicação dos inferidores com estas gramáticas, portanto, só pôde ser analisada segundo o número de produções das gramáticas inferidas. No entanto, estas informações serão discutidas na seção 6.3 como indicativos do comportamento dos inferidores.

\subsubsection{Repetição de testes}

As gramáticas utilizadas no teste possuem difentes tamanhos e exigiram diferentes tempos de execução dos algoritmos. Por esse motivo o número de repetições de testes não foi igual para todas. Os testes de identificação da gramática $G_{S a k}$ por serem muito rápidos, foram repetidos 50 vezes. Os testes de $G_{\text {stem-loop }}, G_{\text {branch }}, G_{n o-\text { reversible }}$ e $G_{\text {codingRegion }}$ foram realizados 5 vezes. No caso da $G_{t R N A}$ os testes não foram repetidos pelo motivo de necessitar de grandes amostras e exigir grande tempo de processamento. Os resultados desses testes apresentados nesse capítulo são as médias obtidas das repetições dos testes para cada gramática.

\subsection{Gramáticas}

Pelo fato do número de símbolos não terminais poder ser arbitrariamente grande, neste capítulo um símbolo não terminal será representado por número delimitado pelos caracteres $<\mathrm{e}>$. 


\subsection{1 $G_{S a k}$}

A gramática $G_{S a k}$ é formada por 14 símbolos não terminais e 18 produções. Ela gera seqüências com tamanhos aproximadamente entre 19 e 29 bases. É uma gramática não ambígua, reversível, não tipo-inversível e com 2 produções recursivas. Suas probabilidades foram atribuídas segundo uma distribuição uniforme.

$$
\begin{aligned}
& <0>\rightarrow<1>\quad[1] \\
& <1>\rightarrow \mathrm{c}<2>\mathrm{g} \quad[.5] \\
& <1>\rightarrow \mathrm{a}<2>\mathrm{u} \quad[.5] \\
& <2>\rightarrow \mathrm{a}<3>\mathrm{u} \quad[1] \\
& <3>\rightarrow<4><9>\quad[1] \\
& <4>\rightarrow \mathrm{u}<5>\mathrm{a} \quad[1] \\
& <5>\rightarrow \mathrm{c}<6>\mathrm{g} \quad[1] \\
& <6>\rightarrow \mathrm{a}<7>\quad[1] \\
& <7>\rightarrow \mathrm{u}<7>\quad[.5] \\
& <7>\rightarrow \mathrm{g}<8>\quad[.5] \\
& <8>\rightarrow \mathrm{g} \quad[.5] \\
& <8>\rightarrow \mathrm{u} \quad[.5] \\
& <9>\rightarrow \mathrm{a}<10>\mathrm{u} \quad[1] \\
& <10>\rightarrow \mathrm{c}<10>\mathrm{g} \quad[.5] \\
& <10>\rightarrow \mathrm{g}<11>\mathrm{c} \quad[.5] \\
& <11>\rightarrow \mathrm{a}<12>\mathrm{u} \quad[1] \\
& <12>\rightarrow \mathrm{u}<13>\quad[1] \\
& <13>\rightarrow \mathrm{c} \quad[1]
\end{aligned}
$$

\section{$6.2 .2 G_{t R N A}$}

Esta gramática foi descrita, incluindo as probabilidades, por Sakakibara [SBU+93] utilizando conhecimento prévio sobre a estrutura secundária geral de tRNAs. Ela é composta por 75 símbolos não terminais e 660 produções das quais 56 são recursivas. A linguagem gerada por ela contém seqüências de 71 a 95 bases. Por se tratar de uma gramática muito longa, encontra-se no apêndice A. 


\subsection{3 $G_{\text {codingRegion }}$}

Esta gramática possui 9 não terminais e 23 produções, das quais apenas 1 é recursiva. As probabilidades foram atribuídas de forma que o gerador de seqüências utilizasse freqüentemente a produção recursiva, a fim de gerar seqüências não muito curtas. Os valores equivalentes a essas probabilidades podem ser informados ao GS como valores inteiros positivos, e ele se encarrega de normalizar esses valores de forma a serem equivalentes a probabilidades.

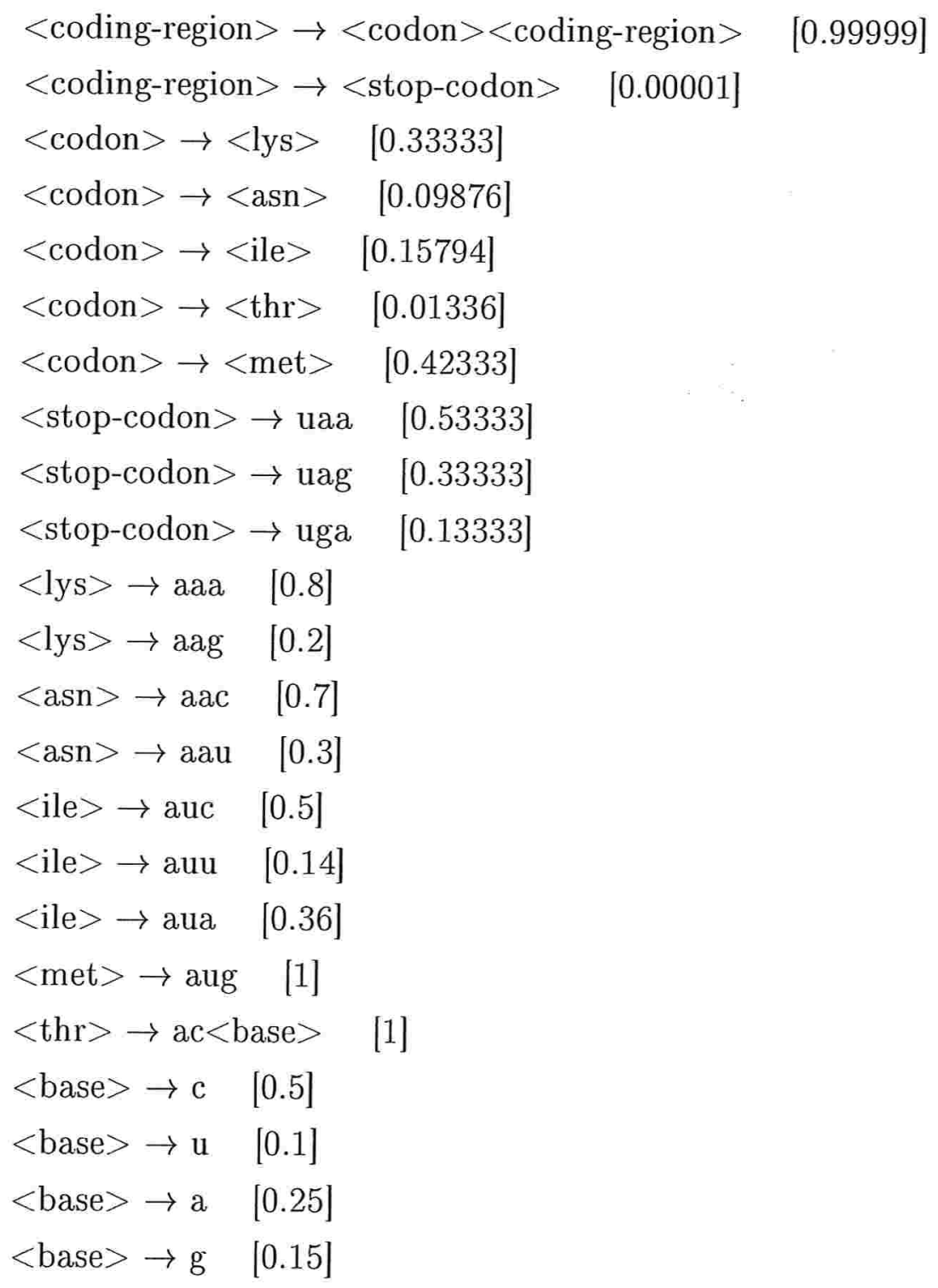




\subsection{4 $G_{\text {stem-loop }}$}

Esta é uma gramática não ambígua, reversível, e tipo-inversível. Possui apenas um único símbolo não terminal, e 12 produções como derivação desse símbolo, das quais 8 são recursivas. As probabilidades foram distribuídas de forma que as produções recursivas fossem mais prováveis aquelas que geram apenas um terminal.

$$
\begin{array}{ll}
<1>\rightarrow \mathrm{c}<1>\mathrm{g} & {[0.152265]} \\
<1>\rightarrow \mathrm{g}<1>\mathrm{c} & {[0.171298]} \\
<1>\rightarrow \mathrm{u}<1>\mathrm{a} & {[0.161781]} \\
<1>\rightarrow \mathrm{a}<1>\mathrm{u} & {[0.133232]} \\
<1>\rightarrow \mathrm{c}<1> & {[0.076132]} \\
<1>\rightarrow \mathrm{g}<1> & {[0.076132]} \\
<1>\rightarrow \mathrm{u}<1> & {[0.114199]} \\
<1>\rightarrow \mathrm{a}<1> & {[0.114199]} \\
<1>\rightarrow \mathrm{a} \quad[0.000190] \\
<1>\rightarrow \mathrm{c} \quad[0.000190] \\
<1>\rightarrow \mathrm{g} \quad[0.000190] \\
<1>\rightarrow \mathrm{u} \quad[0.000190]
\end{array}
$$

\subsection{5 $G_{\text {branch }}$}

Esta gramática é formada por 9 produções, das quais 5 são recursivas. Ela é reversível, e composta pela retirada de quatro produções de $G_{\text {stem-loop }}$ e pela adição de uma produção que possui duas recursões ao símbolo não terminal ${ }^{7}$, o que a torna ambígua. As probabilidades foram distribuídas de forma que as produções recursivas fossem mais prováveis aquelas que geram apenas um terminal. A produção que possui recursão (primeira produção), no entanto, recebeu uma probabilidade menor, a fim de não gerar muitas ramificações.

$$
\begin{aligned}
& <1>\rightarrow<1><1>\quad[0.057904] \\
& <1>\rightarrow c<1>g \quad[0.231616]
\end{aligned}
$$

\footnotetext{
${ }^{7}$ Essa produção adicional é o que a permite modelar ramificaçōes.
} 


$$
\begin{aligned}
& <1>\rightarrow \mathrm{g}<1>\mathrm{c} \quad[0.260567] \\
& <1>\rightarrow \mathrm{u}<1>\mathrm{a} \quad[0.246091] \\
& <1>\rightarrow \mathrm{a}<1>\mathrm{u} \quad[0.202664] \\
& <1>\rightarrow \mathrm{a} \quad[0.000290] \\
& <1>\rightarrow \mathrm{c} \quad[0.000290] \\
& <1>\rightarrow \mathrm{g} \quad[0.000290] \\
& <1>\rightarrow \mathrm{u} \quad[0.000290]
\end{aligned}
$$

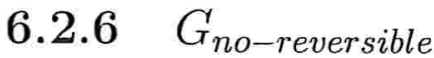

Esta é uma gramática não reversível equivalente a $G_{b r a n c h}$. Contém 11 produções, das quais 6 são recursivas. A distribuição de probabilidades é semelhante à da gramática $G_{\text {branch }}$.

$$
\begin{aligned}
& <1>\rightarrow<1><1>\quad[0.054735] \\
& <1>\rightarrow<1><2>\quad[0.054735] \\
& <2>\rightarrow<1>\quad[1.000000] \\
& <1>\rightarrow \mathrm{c}<1>\mathrm{g} \quad[0.218938] \\
& <1>\rightarrow \mathrm{g}<1>\mathrm{c} \quad[0.246305] \\
& <1>\rightarrow \mathrm{u}<1>\mathrm{a} \quad[0.232622] \\
& <1>\rightarrow \mathrm{a}<1>\mathrm{u} \quad[0.191571] \\
& <1>\rightarrow \mathrm{a} \quad[0.000274] \\
& <1>\rightarrow \mathrm{c} \quad[0.000274] \\
& <1>\rightarrow \mathrm{g} \quad[0.000274] \\
& <1>\rightarrow \mathrm{u} \quad[0.000274]
\end{aligned}
$$

\subsection{Análise dos inferidores gramaticais}

Pelo fato de ter sido possível a realização dos testes de falsos positivos e falsos negativos

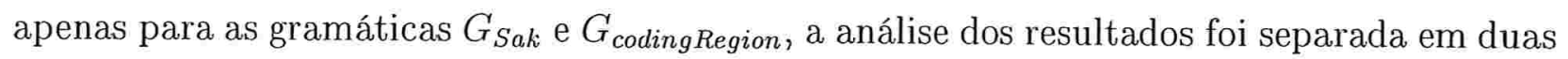
seções. A seção 6.3.1 apresenta a análise da evolução do número de produções e testes de

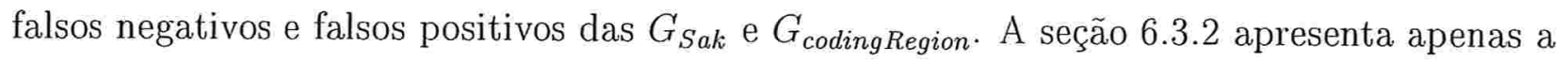
análise da evolução do número de produções das demais gramáticas. 


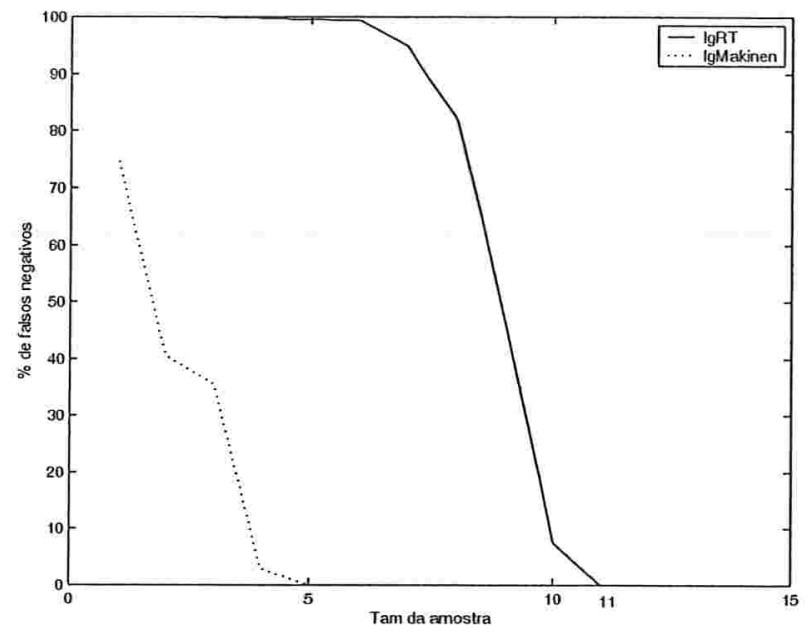

Figura 6.2: Falsos negativos de $G_{S a k}$ utilizando $I G_{R T}$ e $I G_{M a k i n e n}$

Os gráficos apresentados nesta seção comparam as curvas originadas pelos inferidores $I G_{R T}$ e $I G_{\text {Makinen. }}$ Em alguns deles, a escala necessária para descrever a curva originada por $I G_{R T}$ não permite uma visualização mais detalhada da curva originada por $I G_{M a k i n e n}$. Desta forma adicionamos alguns gráficos de $I G_{\text {Makinen }}$ separadamente.

\subsubsection{Análise dos resultados de $G_{S a k}$ e $G_{\text {codingRegion }}$}

As figuras 6.2 a 6.7 , revelam semelhanças e diferenças entre os processos de inferência

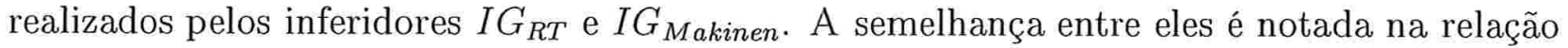
entre a diminuição da taxa de falsos negativos das gramáticas inferidas e a estabilização do número médio de produções. A diferença está no processo de evolução dos números de produções e os tamanhos de amostra necessários para não apresentar falsos negativos.

Foram omitidos os gráficos das taxas de falsos positivos, pois todas as curvas apresentaramse constantes em $0 \%$ com exceção das gramáticas $G_{S a k}$ inferidas por $I G_{M a k i n e n}$, que mesmo assim apresentou valores muito baixos, conforme apresentado a seguir.

Identificação e poder de reconhecimento Os quatro testes envolvendo as gramáticas $G_{\text {Sak }}$ e $G_{\text {codingRegion }}$ e os inferidores $I G_{R T}$ e $I G_{\text {Makinen }}$ apresentaram uma estabilização do número de produções no mesmo instante em que alcançaram o ponto de $0 \%$ de falsos negativos. Em cada teste, as gramáticas inferidas após o ponto de estabilização não sofreram mais 


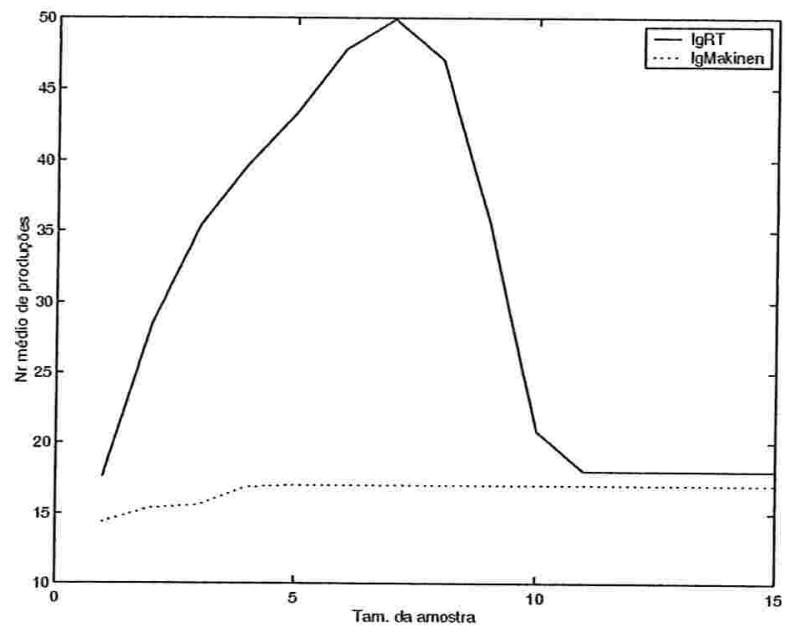

Figura 6.3: Número de produções de $G_{S a k}$ utilizando $I G_{R T}$ e $I G_{M a k i n e n}$

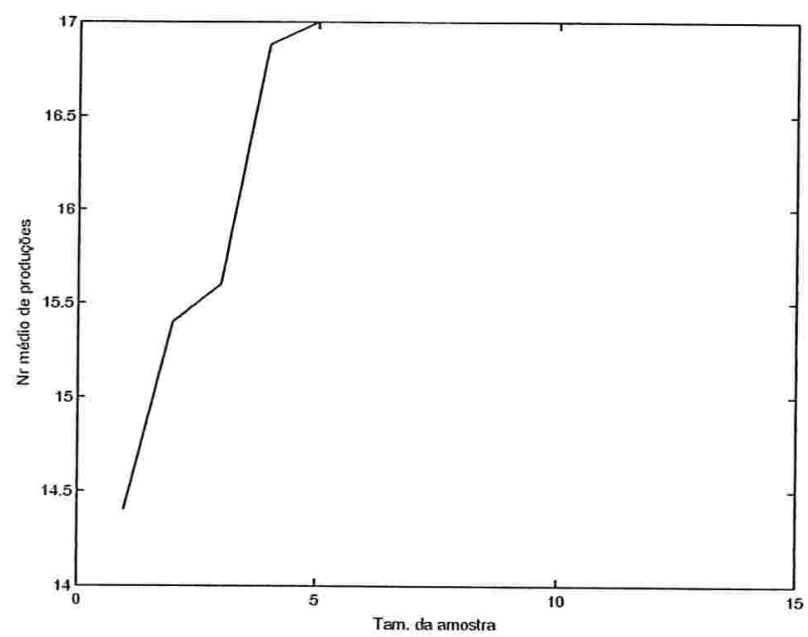

Figura 6.4: Número de produções de $G_{S a k}$ utilizando $I G_{M a k i n e n}$ 


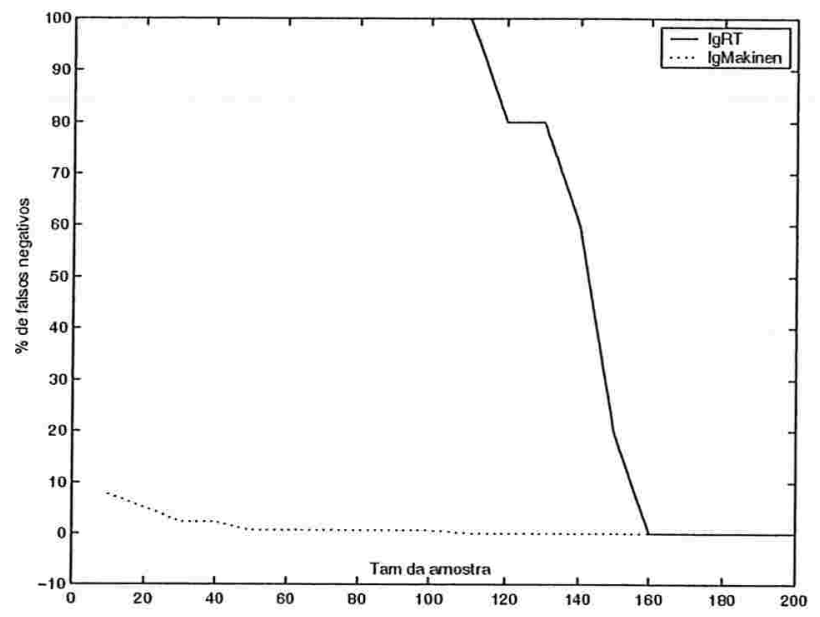

Figura 6.5: Falsos negativos de $G_{\text {codingRegion }}$ utilizando $I G_{R T}$ e $I G_{\text {Makinen }}$

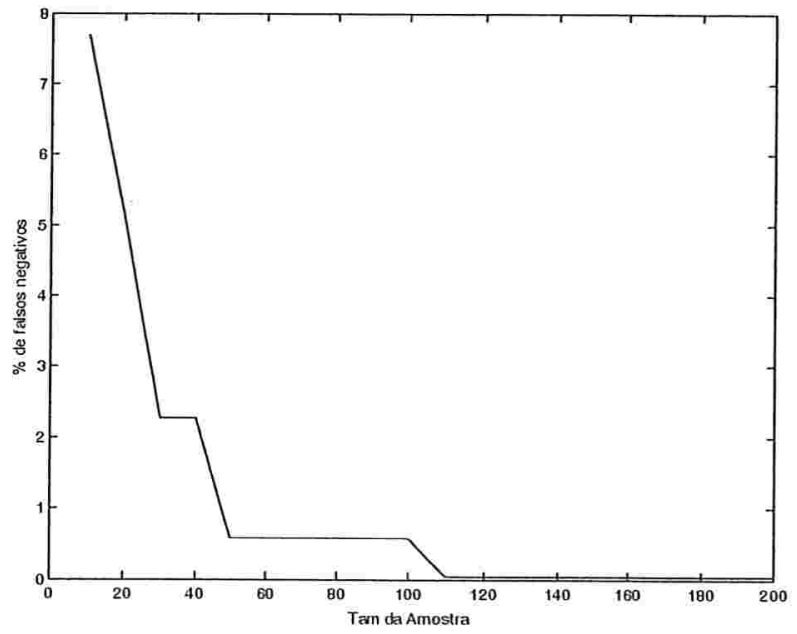

Figura 6.6: Falsos negativos de $G_{\text {codingRegion }}$ utilizando $I G_{\text {Makinen }}$ 


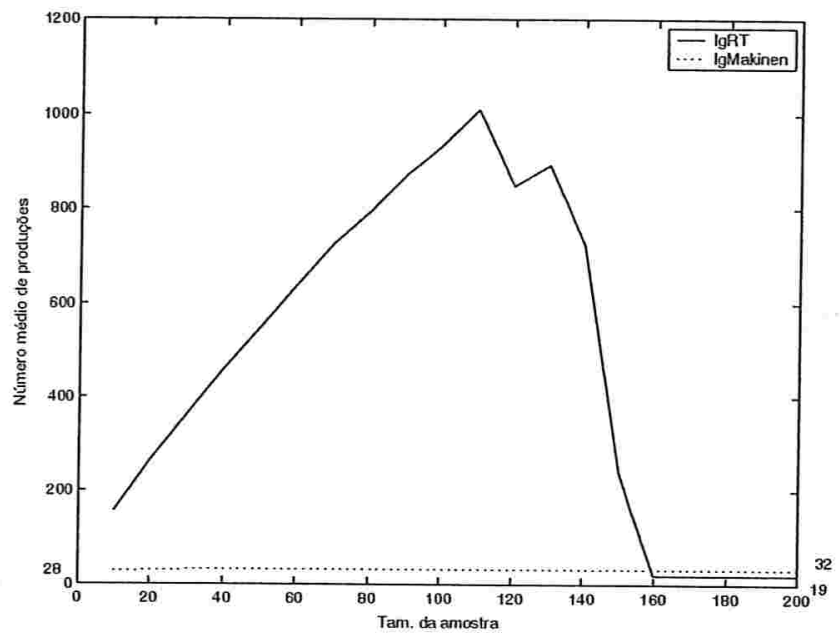

Figura 6.7: Número de produções de $G_{\text {codingRegion }}$ utilizando $I G_{R T}$ e $I G_{\text {Makinen }}$

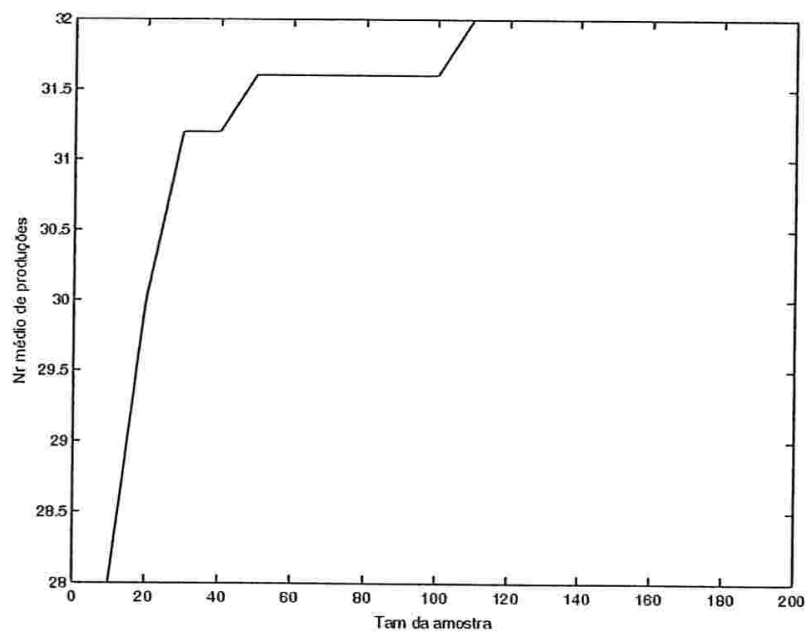

Figura 6.8: Número de produções de $G_{\text {codingRegion }}$ utilizando $I G_{\text {Makinen }}$ 
alterações com o aumento do tamanho da amostra, indicando convergência das gramáticas inferidas.

A gramática $G_{S a k}$ pôde ser identificada pelo inferidor $I G_{R T}{ }^{8}$, isto é, a gramática na qual o processo convergiu é equivalente à $G_{S a k}$ original. O mesmo não ocorreu com $I G_{\text {Makinen }}$

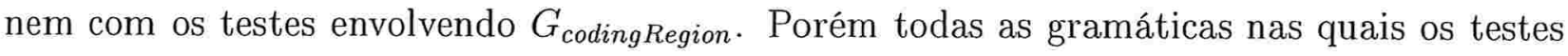
convergiram apresentaram $0 \%$ de falsos negativos.

Nos testes de $G_{S a k}$ utilizando $I G_{\text {Makinen }}$ foi observada uma taxa de falsos positivos crescente até sua estabilização no ponto de convergência. No entanto esse ponto máximo ocorreu em um valor não significativo: $0.08 \%$. Os demais testes apresentaram $0 \%$ de falsos positivos durante todo o processo de inferência.

Evolução do número de produções As figuras 6.3 e 6.7 revelam uma diferença marcante entre as curvas do número de produções das gramáticas inferidas por $I G_{R T}$ e $I G_{\text {Makinen }}$. As curvas obtidas pelo $I G_{R T}$ foram caracterizadas por uma fase crescente e uma decrescente, enquanto o $I G_{\text {Makinen }}$ produz uma curva de crescimento mais suave e somente crescente.

Esses dados são um indício de que a observação do número de produções das gramáticas inferidas pode fornecer dicas sobre a confiabilidade de uma gramática produzida por um desses inferidores. Segundo esses testes, enquanto gramáticas inferidas pelo $I G_{R T}$ apresentar aumento no número de produções, esta gramática não pode ser considerada uma boa aproximação da gramática alvo.

Reconhecimento e tamanhos de amostras As figuras 6.2 e 6.5 mostram que as gramáticas inferidas por $I G_{\text {Makinen }}$ alcançaram o ponto de $0 \%$ de falsos negativos com amostras menores que as inferidas por $I G_{R T}$, sem apresentar taxa de falsos positivos significativa. Mesmo antes de atingir essa marca, uma taxa baixa foi atingida com amostras pequenas. Veja na figura 6.5 que, enquanto o inferidor $I G_{R T}$ precisou de 120 seqüências para diminuir seu erro de $100 \%$ para $80 \%$, o $I G_{\text {Makinen }}$ com 10 seqüências foi capaz de atingir apenas $7.7 \%$ de erro. Isso indica que a utilização do inferidor $I G_{\text {Makinen }}$ pode ser mais apropriada para o contexto biológico, onde não dispomos de grande número de sequiências para compor as amostras de treinamento.

\footnotetext{
${ }^{8}$ Note que a $G_{S a k}$ é reversível, e o algoritmo $I G_{R T}$ infere gramáticas reversíveis.
} 


\subsubsection{Análise dos resultados das demais gramáticas}

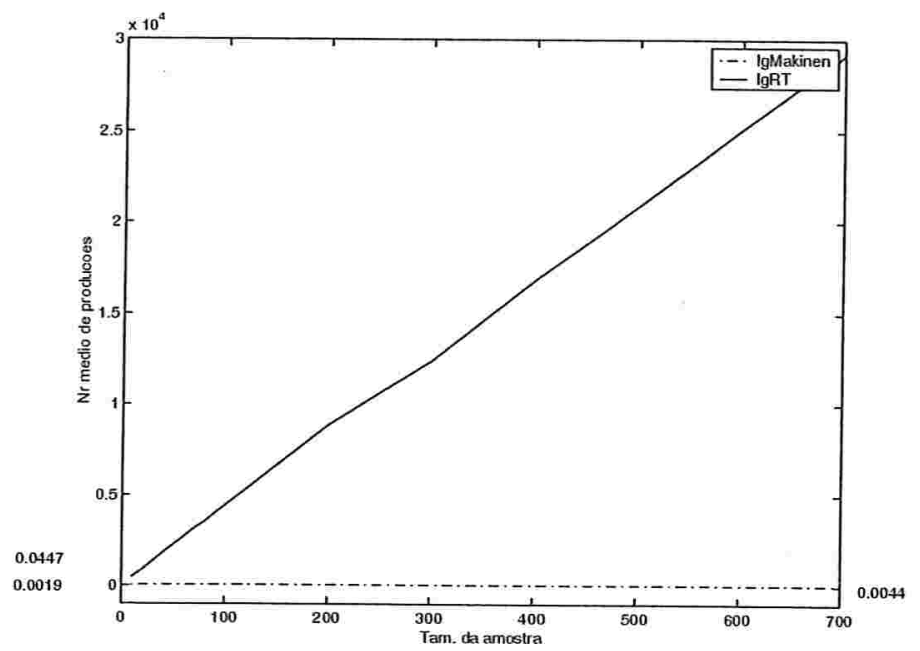

Figura 6.9: Número de produções de $G_{\text {stem-loop }}$ utilizando $I G_{R T}$ e $I G_{\text {Makinen }}$

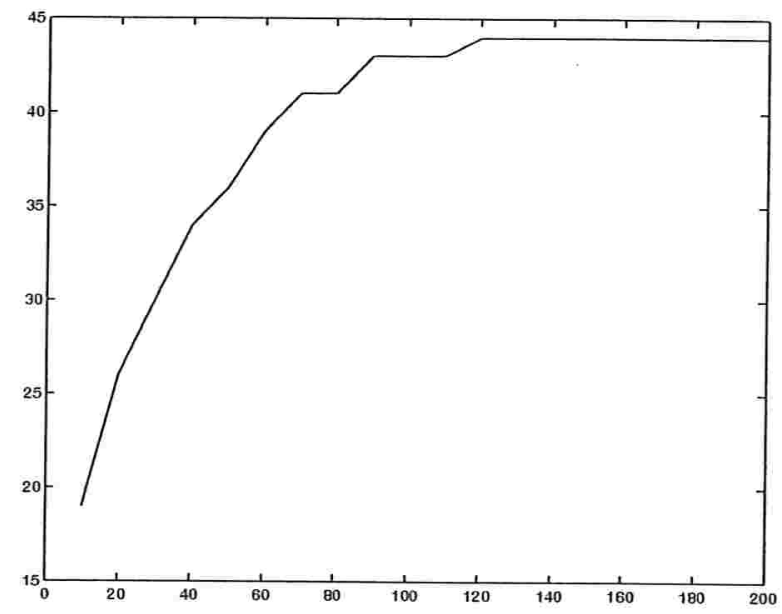

Figura 6.10: Número de produções de $G_{\text {stem-loop }}$ utilizando $I G_{\text {Makinen }}$

O comportamento das curvas de números de produções dos testes envolvendo $G_{S a k}$ e $G_{\text {cdons }}$ repetiu-se com quase todas as demais gramáticas, cujas curvas podem ser vistas nas figuras 6.9 a 6.15 .

Os processos de inferência utilizando $I G_{R T}$ apresentou a mesma curva crescente e decrescente com as gramáticas $G_{\text {branch }}$ e $G_{n o-r e v e r s i b l e}$. No entanto, para as gramáticas $G_{\text {stem-loop }}$ e 


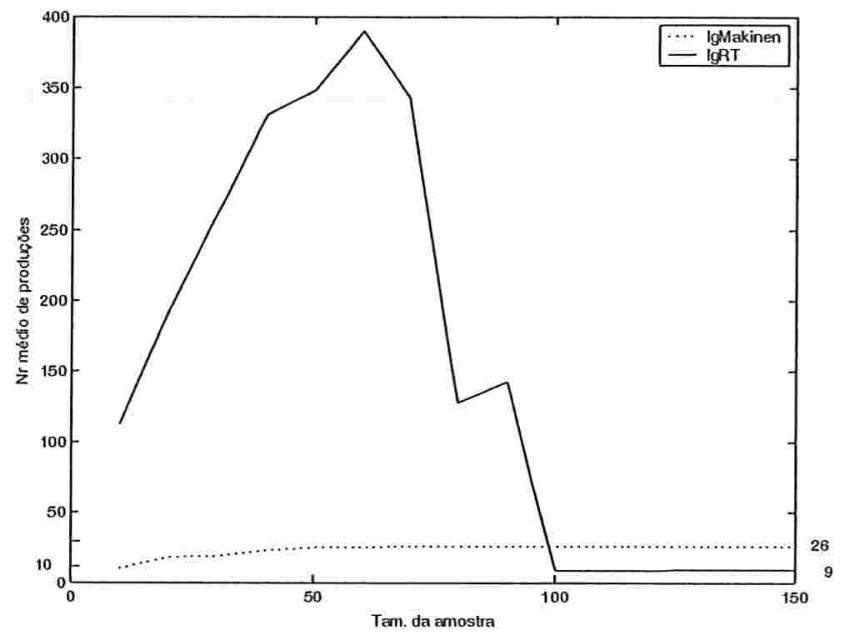

Figura 6.11: Número de produções de $G_{n o-r e v e r s i b l e ~}$ utilizando $I G_{R T}$ e $I G_{\text {Makinen }}$

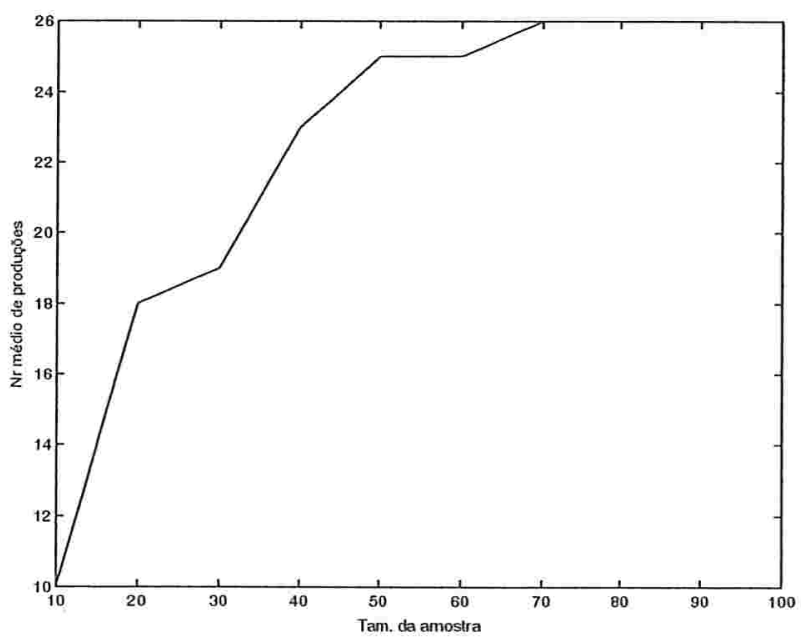

Figura 6.12: Número de produções de $G_{n o-r e v e r s i b l e ~}$ utilizando $I G_{\text {Makinen }}$ 


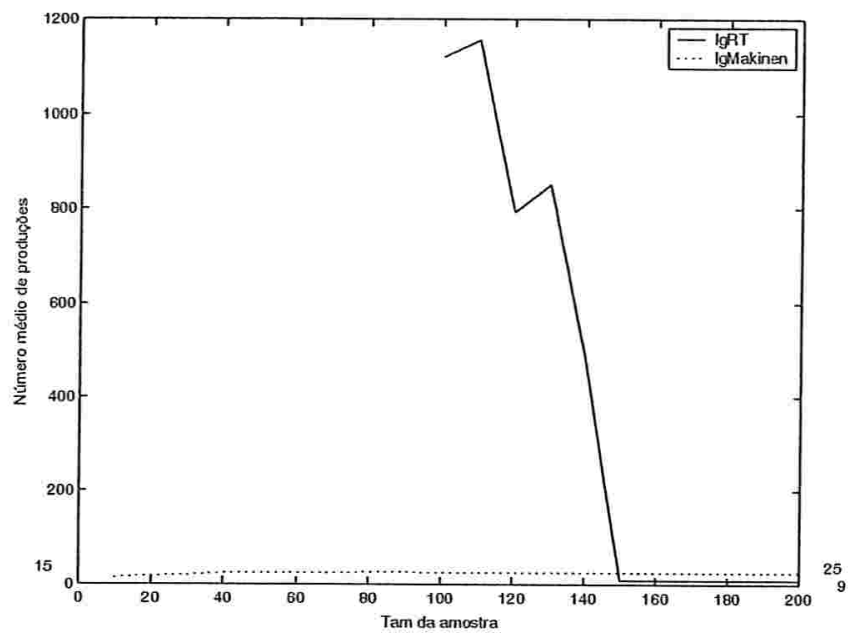

Figura 6.13: Número de produções de $G_{b r a n c h}$ utilizando $I G_{R T}$ e $I G_{\text {Makinen }}$

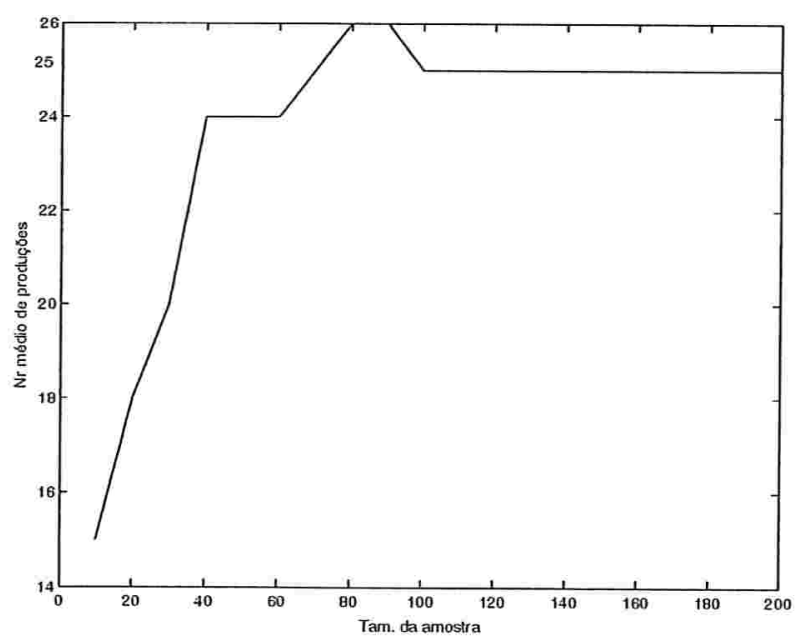

Figura 6.14: Número de produções de $G_{\text {branch }}$ utilizando $I G_{\text {Makinen }}$ 


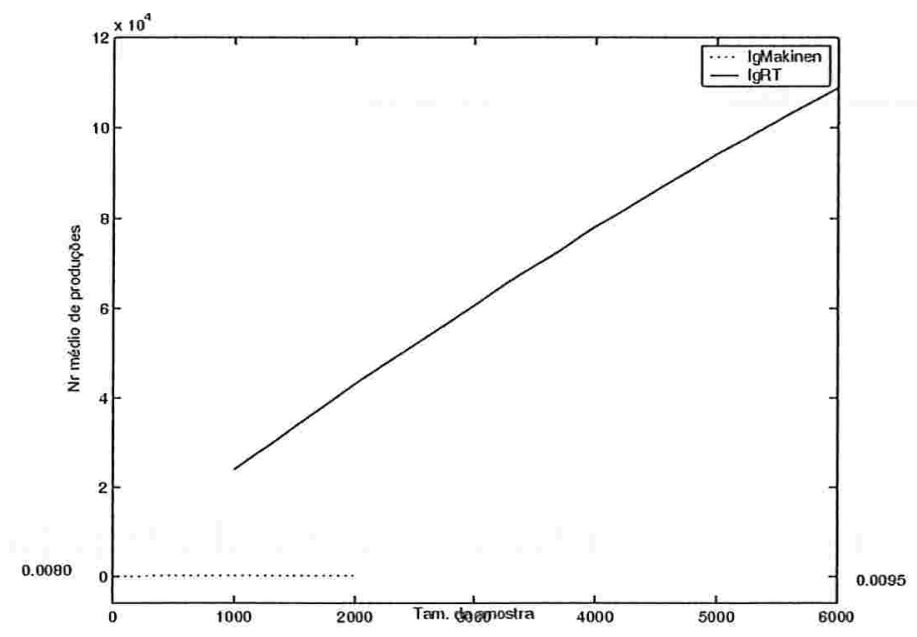

Figura 6.15: Número de produções de $G_{t R N A}$ utilizando $I G_{R T}$ e $I G_{\text {Makinen }}$

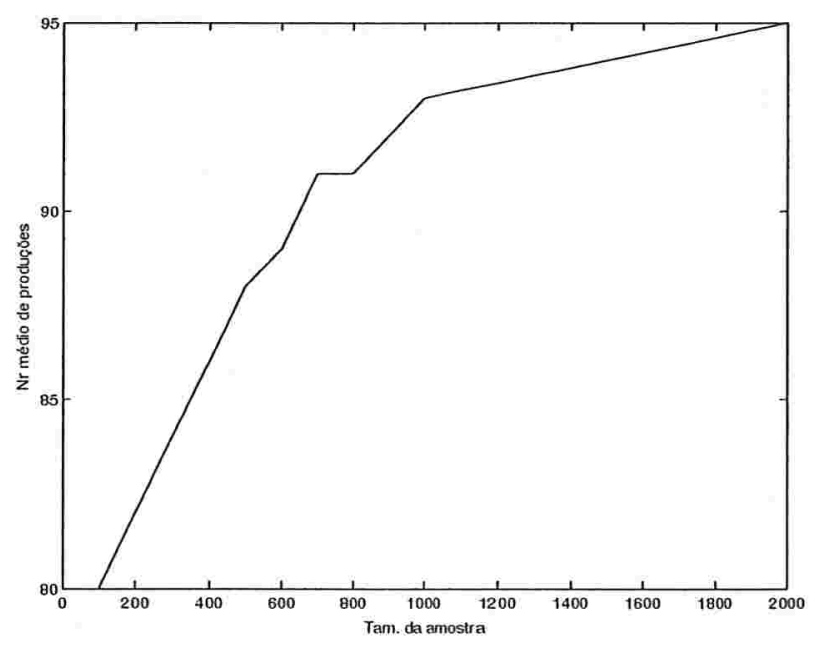

Figura 6.16: Número de produções de $G_{t R N A}$ utilizando $I G_{\text {Makinen }}$ 
$G_{t R N A}$ notou-se apenas a fase crescente, não chegando a uma covergência. Desta forma não foi possível observar uma influência das propriedades de reversibilidade ${ }^{9}$ e ambigüidade no processo de convergência do inferidor $I G_{R T}$. Não foi possível realizar testes com amostras maiores por falta de memória.

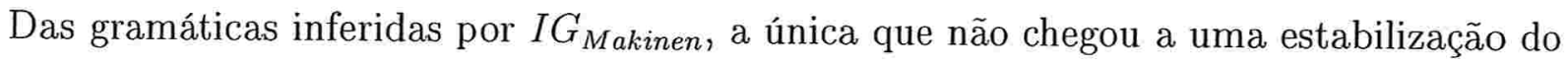
número de produções foi a $G_{t R N A}$. No entanto, até o tamanho de amostra possível para os testes ${ }^{10}$ o comportamento da curva foi igual a de todos os processos de inferência de $I G_{\text {Makinen: }}$ uma curva suavemente crescente.

\subsection{Análise dos estimadores de probabilidades}

A análise dos estimadores de probabilidades será baseada na análise do erro médio relativo $^{11}$ das probabilidades atribuídas pelos classificadores gerados às seqüências de teste. Para cada gramática foram descritas quatro curvas de erro, uma para cada classificador: $I G_{R T}+$ $E P_{F u}, I G_{R T}+E P_{T G R}, I G_{M a k i n e n}+E P_{F u}$ e $I G_{M a k i n e n}+E P_{T G R}$. Serão analisados ape-

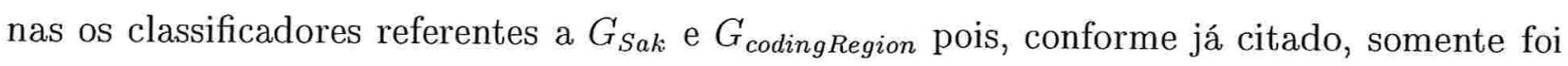
possível a execução do analisador sintático para estas gramáticas.

As figuras 6.17 e 6.18 mostram que as curvas de erro sofreram mais influência do inferidor do que do estimador. Ou seja, a estrutura da gramática não estocástica foi um fator determinante da qualidade do classificador final.

Enquanto as curvas dos erros das gramáticas inferidas pelo $I G_{\text {Makinen }}$ permaneceram próximas do valor zero, as curvas dos erros das gramáticas inferidas pelo $I G_{R T}$ apresentam uma fase com altos valores de erros que coincide com os altos valores da curva de número de produções. A figura 6.17 referente a $G_{S a k}$ mostra um pico de erro dos estimadores baseados em gramáticas inferidas por $I G_{R T}$. Esse pico coincide com o pico do número de produções das gramáticas $G_{S a k}$ produzidas por este inferidor (figura 6.3). Nos testes realizados para a

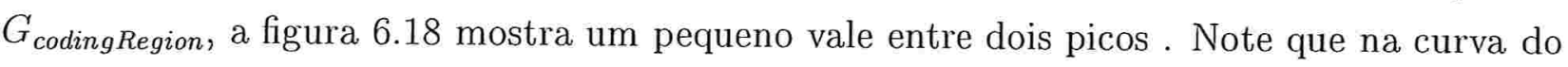
número de produções desta gramática (6.7) há um comportamento semelhante.

As figuras 6.19 e 6.20 apresentam apenas as curvas dos classificadores baseados em

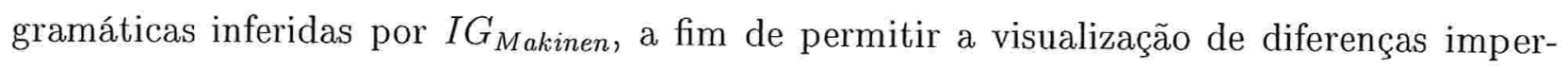

\footnotetext{
${ }^{9}$ Essa propriedade foi avaliada pelo fato do $I G_{R T}$ inferir gramáticas reversíveis.

${ }^{10}$ Testes com amostras maiores também não foi possível por falta de memória.

${ }^{11} \mathrm{Na}$ seção 6.1.1 descrevemos como esse erro é calculado.
} 


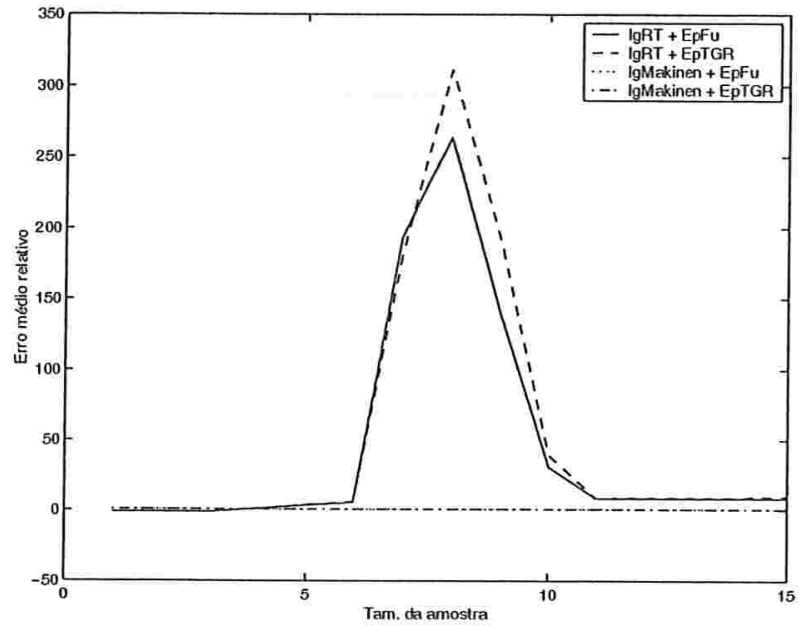

Figura 6.17: Erro médio relativo das probabilidades de $G_{S a k}$

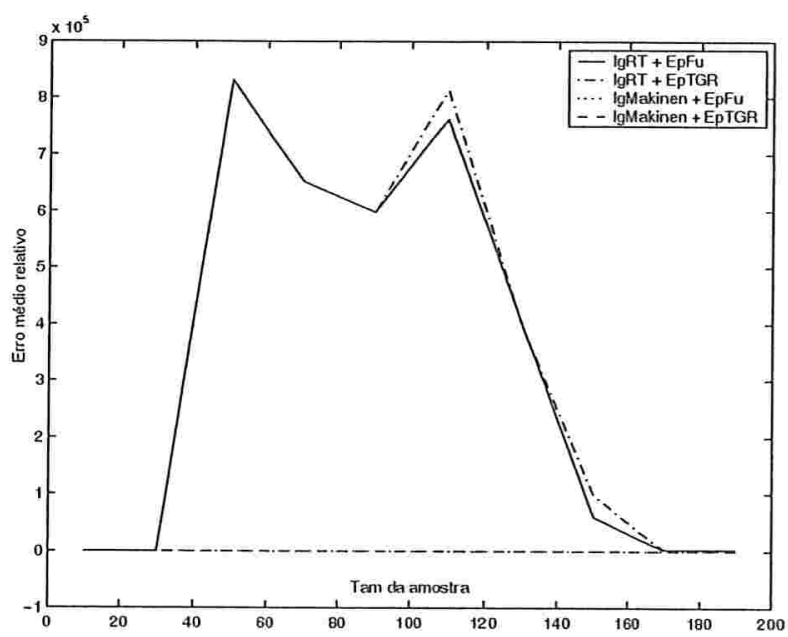

Figura 6.18: Erro médio relativo das probabilidades de $G_{\text {codingRegion }}$ 


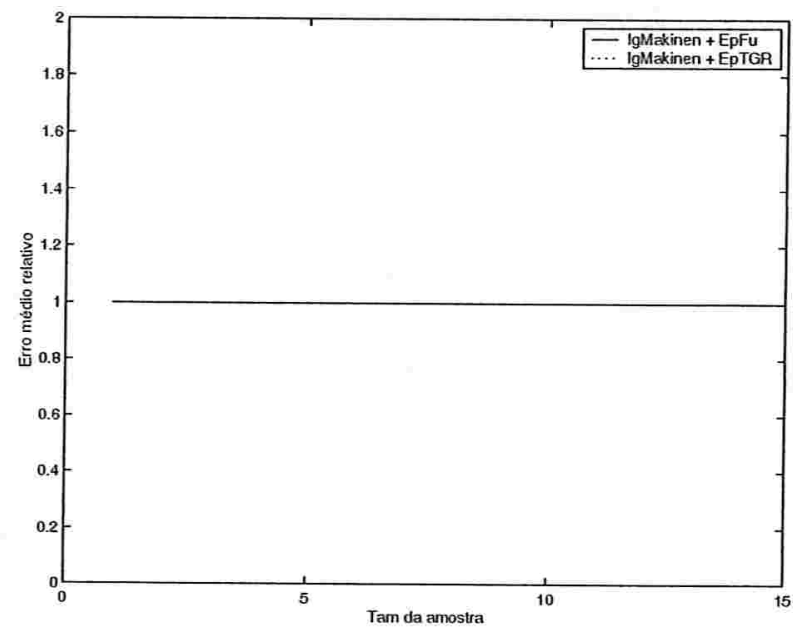

Figura 6.19: Erro médio relativo das probabilidades de $G_{S a k}$

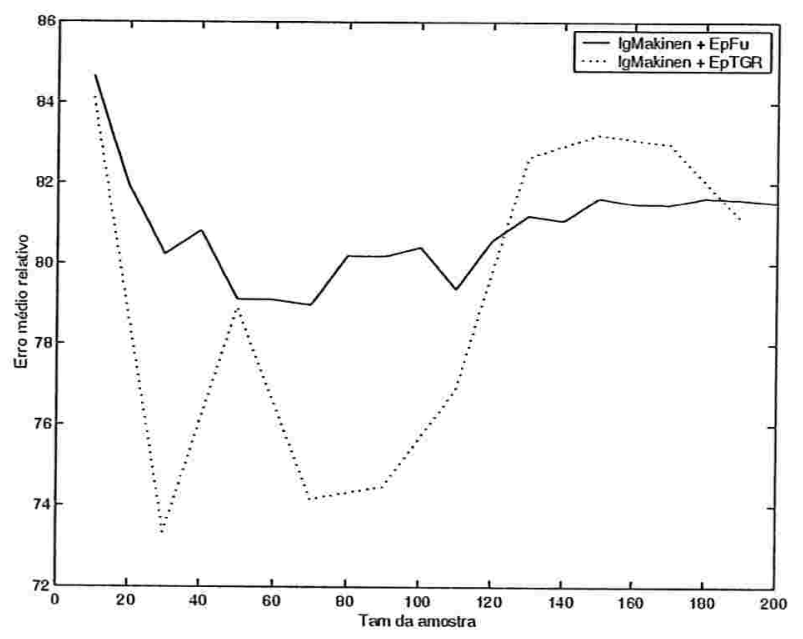

Figura 6.20: Erro médio relativo das probabilidades de $G_{\text {codingRegion }}$ 
ceptíveis pela alta escala necessária às curvas dos classificadores gerados com $I G_{R T}$.

As curvas de erros da figura 6.19 referentes a $G_{S a k}$ são constantes no valor 1 . Na verdade os valores dos erros possuem uma variação depois da quinta casa decimal, o que não pode ser visto nos gráficos.

A figura 6.20 mostra as curvas de erro referentes a $G_{\text {codingRegion. Durante a primeira parte }}$ dos testes o estimador $E P_{T G R}$ apresenta erro inferior a $E P_{F u}$, sofrendo depois uma inversão. Pouco depois uma nova inversão ocorre, mostrando uma instabilidade entre os resultados dos estimadores.

Como era esperado, os resultados evidenciaram a influência da gramática não estocástica na qualidade da estimação. Quanto aos estimadores, comparando as figuras 6.17 a 6.20, não é possível afirmar qual deles é o melhor. Outros testes poderiam ter sido feitos, envolvendo mais gramáticas e maior número de amostras. No entanto, restringimos os testes aos apresentados nesta seção pelo fato da proposta deste trabalho se limitar ao desenvolvimento do laboratório e a uma avaliação preliminar de alguns algoritmos, servindo de suporte para pesquisas futuras. 



\section{Conclusão}

\subsection{Principais resultados obtidos}

Neste trabalho foi desenvolvido um arcabouço capaz de dar suporte a implementações de algoritmos de aprendizado de gramáticas estocásticas, geração de classificadores e testes dos mesmos. Como parte do arcabouço, foram implementados dois algoritmos de inferência gramatical $\left(I G_{R T}\right.$ e $\left.I G_{\text {Makinen }}\right)$ e algoritmos de estimação de probabilidades $\left(E P_{F u}\right.$ e $\left.E P_{T G R}\right)$.

Visando facilitar o desenvolvimento de novos algoritmos de aprendizando foram implementadas as classes Grammar para manipulação de gramáticas, TreeAutomaton para manipulação de autômatos a árvores, Trie para manipulação de tries, EarleyParser para implementar o algoritmo de Earley e a coleção Stream para implementar entrada e saída de dados.

Para o suporte a testes foram desenvolvidos programas para manipulação de arquivos de seqüências, de descrição de gramáticas e de dados obtidos de testes. Também foi desenvolvido um programa encarregado de executar todo o processo de testes sem necessidade de interação.

Durante a implementação dos algoritmos de inferência foram detectadas falhas na descrição do algoritmo $I G_{R T}$, incluindo um erro algoritmico. Essas falhas causaram alto consumo de memória, alto tempo de execução e inferência de gramáticas erradas. Neste trabalho o erro foi corrigido e os consumos de memória e tempo foram diminuídos.

Nos testes dos algoritmos pudemos verificar a viabilidade do uso da abordagem de gramáticas livres de contexto na caracterização de famílias biológicas. O algoritmo inferidor $I G_{\text {Makinen }}$ apresentou resultados que indicam uma aplicabilidade promissora na modelagem 
de seqüências genéticas que o inferidor $I G_{R T}$. No caso da $G_{\text {codingRegion }}$ ele foi capaz de inferir uma gramática com $7.7 \%$ de falsos negativos com apenas 10 seqüências, e de inferir uma gramática com $2.27 \%$ de falsos negativos com 30 seqüências, sem apresentar falsos positivos. Com a gramática $G_{S a k}$ esses resultados foram ainda melhores. Além de ser capaz de aproximar a gramática alvo com amostras menores que o $I G_{R T}$, também influenciou o processo de estimação das probabilidades. Esses dados indicam que o uso inferidor $I G_{M a k i n e n}$ pode ser explorado na geração de classificadores de seqüências genéticas, fornecendo maior possibilidade de acerto no levantamento de hipóteses sobre classificações de seqüências armazenadas nos vários bancos de dados genéticos.

Os resultados envolvendo o inferidor $I G_{R T}$ indicam que este inferidor não possui uma boa aplicabilidade na inferência de seqüências biológicas. Isto deve-se ao fato de que, enquanto ele não atinge o ponto de convergência, as gramáticas inferidas por ele apresentam uma taxa alta de falsos negativos. Além disso, em todos os testes esse ponto de convergência foi maior que o ponto de convergência do inferidor $I G_{\text {Makinen }}$.

Quanto aos estimadores não foi possível concluir qual deles apresenta melhores resultados. Outros testes deveriam ser feitos explorando, por exemplo, a diferença de comportamento dos dois estimadores com uma gramática descrita manualmente ou inferida por uma amostra diferente da utilizada pelos estimadores.

\subsection{Trabalhos futuros}

Exploração do uso do inferidor $I G_{\text {Makinen }}$ O inferidor $I G_{\text {Makinen }}$ apresentou resultados que indicam uma aplicabilidade promissora na modelagem de famílias de seqüências genéticas. O próximo passo é testar esse algoritmo a partir de várias outras gramáticas, a fim de verificar se esses resultados se repetem. Para isso será necessária a utilização de analisadores sintáticos mais eficientes, e assim realizar testes de falsos positivos e falsos negativos.

Uso de amostras negativas e oráculos adaptados Ao limitar o escopo de pesquisa dos algoritmos a serem implementados descartamos, por exemplo, algoritmos que utilizam a abordagem de oráculos pelo fato de desconhecermos em biologia molecular uma fonte de informações que desempenhe esse papel. No entanto poderia ser estudado o uso de algum conhecimento acerca das famílias a serem caracterizadas. Por exemplo, se é conhecido que uma família de seqüências não pode apresentar determinadas estruturas, é possível contruir 
uma amostra de treinamento negativa contendo seqüências que apresentem essas estruturas. Com essa amostra podemos aplicar algoritmos de inferência que façam uso dessa informação, como [NI00] ou [Gio94]. Poderiam também ser estudadas adaptações em algoritmos baseados em oráculos [STSH00], [Sak90]. Uma estratégia que pode ser investigada é desenvolver um oráculo de forma que, quando ele não "souber"uma resposta, procura desenvolver uma baseada em alguma heurística.

Utilização de gramáticas iniciais em algoritmos de inferência Outra forma de aproveitamento de conhecimento bioquímico seria se tivéssemos a possibilidade de fornecer uma gramática inicial ao inferidor, ao invés de inferir a gramática somente a partir da amostra de treinamento. Essa gramática inicial modelaria algumas estruturas conhecidas acerca da família a ser caracterizada. Nenhum trabalho foi encontrado neste sentido. No entanto poderia ser estudada a possibilidade de adaptar algoritmos que manipulam autômatos a árvores (como o $I G_{R T}$ ) para receberem alguns autômatos que seriam agregados aos autômatos das seqüências de treinamento antes da fase de agrupamento de blocos.

Utilização de estruturas parciais A exigência de inferir gramáticas através de seqüências estruturadas pode limitar o tamanho da amostra de treinamento no caso de possuir seqüências de exemplos das quais sua parentisação é desonhecida. Foi encontrado na literatura um trabalho que lida com seqüências parcialmente estruturadas [SM00]. Poderia ser estudada a possibilidade desta abordagem.

Aplicação de outras classes gramaticais Outra questão que poderia ser explorada é a aplicação de outras classes gramaticais. Gramáticas lineares, por exemplo, são capazes de descrever laços, e são alvos de algoritmos inferidores mais eficientes [SF00], [Mäk98]. Um estudo mais profundo sobre uma variedade de classes gramaticais pode ser feito no sentido de tentar delinear quais são capazes de modelar quais estruturas. Dessa forma a aplicação de inferência gramatical pode ser feita seletivamente para diferentes tipos de estruturas biológicas a serem caracterizadas. Poderia ser estudado, inclusive, a possibilidade de inferir separadamente partes de uma estrutura, cada uma com um algoritmo de inferência, e posteriormente combinar as gramáticas resultantes. 
Inserção de produções de erro Seqüências genéticas podem sofrer mutações ao longo do tempo, conforme citado na seção 2.4.1. Essas mutações podem ser modeladas através da inserção de produções de erro. Essas produções modelam a substituição de um terminal por outro, ou a deleção deste. Assim, cada terminal seria substituído por um não terminal, que por sua vez podem produzir qualquer terminal ou a seqüência vazia $(\varepsilon)$. Se, por exemplo, para o não terminal $\langle\mathrm{S}\rangle$ temos as produções

$\mathrm{S} \rightarrow \mathrm{aBu}$
$\mathrm{S} \rightarrow \mathrm{cBg}$

uma utilização de produções de erro poderia ser
$\mathrm{S} \rightarrow \mathrm{ABU}$
$\mathrm{S} \rightarrow \mathrm{CBG}$
$\mathrm{A} \rightarrow \mathrm{a}$
$\mathrm{A} \rightarrow \mathrm{u}$
$\mathrm{A} \rightarrow \mathrm{g}$
$\mathrm{A} \rightarrow \mathrm{C}$
$\mathrm{A} \rightarrow \varepsilon$
$\mathrm{C} \rightarrow \mathrm{a}$
$\mathrm{C} \rightarrow \mathrm{u}$
$\mathrm{C} \rightarrow \mathrm{g}$
$\mathrm{C} \rightarrow \mathrm{C}$
$\mathrm{C} \rightarrow \varepsilon$
$\mathrm{G} \rightarrow \mathrm{a}$
$\mathrm{G} \rightarrow \mathrm{u}$
$\mathrm{G} \rightarrow \mathrm{g}$
$\mathrm{G} \rightarrow \mathrm{c}$
$\mathrm{G} \rightarrow \varepsilon$
$\mathrm{U} \rightarrow \mathrm{a}$
$\mathrm{U} \rightarrow \mathrm{u}$
$\mathrm{U} \rightarrow \mathrm{g}$ 


$$
\begin{aligned}
& \mathrm{U} \rightarrow \mathrm{c} \\
& \mathrm{U} \rightarrow \varepsilon
\end{aligned}
$$

A inserção de produções de erro pode ocorrer após a fase de estimação de probabilidades. Essas produções recebem uma probabilidade baixa, que pode ser extraída de informação biológica sobre a taxa de mutação em determinados tipos de seqüências. Assim, produções que modelam uma associação correta $(\mathrm{A} \rightarrow \mathrm{a}, \mathrm{C} \rightarrow \mathrm{c}, \mathrm{G} \rightarrow \mathrm{g}, \mathrm{U} \rightarrow \mathrm{u})$ recebam probabilidade maior que as modelam substituições e deleções. Desta forma, a gramática treinada será capaz de reconhecer muito mais seqüências, possivelmente até muitas que não pertençam à família. No entanto, quando o classificador é gerado a partir de mais de uma família, irá considerar a probabilidade das seqüências para decidir sua classificação, que será influenciada pelo uso das produções de erro. Desta forma, se por um lado a utilização desse tipo de produções permite o reconhecimento da seqüência, por outro exige uma penalização por seu uso, o que influenciará na decisão final de classificação.

Utilização da estrutura Trie Embora tenha sido encontrado apenas o artigo de Makinen [Mak92] que utilize a estrutura de trie em algoritmos de inferência ${ }^{1}$, ele mostra como seria a implementação do inferidor $I G_{R T}$ de Sakakibara utilizando essa estrutura. Essa nova implementação baseia-se na associação entre tries e autômatos a árvores, descrita na seção 3.4.2. Poderia ser explorado o uso dessa associação nos demais algoritmos que utilizam autômatos a árvores.

Classificadores não binários Os testes realizados neste trabalho utilizam apenas classificadores binários (referentes a apenas uma gramática). No entanto, este arcabouço pode ser aplicado para a geração de classificadores referentes a várias famílias de seqüências. Classificadores desse tipo podem ser úteis na classificação de uma família em subfamílias, por exemplo, na classificação de genes de hemoglobina em genes de hemoglobina de mamíferos, de aves, etc. Para isso é preciso aprender uma gramática para cada amostra de família e utilizar classificação bayesiana (seção 2.5) para fornecer a classificação de uma seqüência testada.

\footnotetext{
${ }^{1}$ Tries são usadas para representar conjuntos sobre os quais se deseja efetuar buscas por prefixos, por exemplo, um dicionário [All].
} 
Predição de estruturas secundárias Gramáticas livres de contexto são úteis para representar estruturas secundárias de RNA, conforme apresentado na seção 2.4. Essa característica poderia ser explorada na busca de preditores dessas estruturas. Para gerar e testar preditores deveriam ser implementados pelo menos dois algoritmos: um para detecção da estrutura de uma seqüência e outro para a comparação de duas estruturas. O primeiro algoritmo pode usar uma estratégia semelhante à do analisador sintático. Este último implementa um algoritmo que é passado ao componente EarleyParser para calcular a probabilidade da seqüência analisada. Utilizando novamente o componente EarleyParser, basta implementar uma variação deste algoritmo que, em lugar de somar a probabilidade de cada derivação da seqüência, retorna a árvore da derivação que apresentou maior probabilidade. O segundo algoritmo visa o teste dos preditores, de forma a comparar a estrutura predita pela gramática aprendida e a estrutura fornecida pela gramática original. Para isso precisam ser pesquisados métodos de comparação de árvores.

Ampliação da coleção Stream A coleção de classes de streams, descrita na seção 5.3.1, implementa apenas as classes que foram utilizadas neste trabalho. Na mesma seção foram apresentadas possíveis extensões dessas classes, como PipeInputStream, PipeOutputStream, BufferInputStream e BufferOutputStream. Estas classes e outras classes podem ser futuramente implementadas de forma a ampliar a coleção Stream para um pacote de classes de tratamento de entrada e saída semelhante ao pacote java.io de Java [Fla99]. 


\section{Gramática $g_{t R N A}$}

$$
\begin{aligned}
& \langle\mathrm{S}\rangle::=\langle 1\rangle\langle 75\rangle[1] \\
& \langle 76\rangle::=\langle 11\rangle\langle 77\rangle \quad \text { [1] } \\
& \langle 78\rangle::=\langle 27\rangle\langle 79\rangle \text { [1] } \\
& <1>::=\mathrm{C}<2>\mathrm{C} \quad[0.004207] \\
& <1>::=\mathrm{C}<2>\mathrm{U}[0.004282] \\
& <1>::=G<2>C \quad[0.650489] \\
& <1>::=\mathrm{G}<2>\mathrm{U} \quad[0.059865] \\
& <1>::=\mathrm{U}<2>\mathrm{C} \quad[0.000360] \\
& <1>::=\mathrm{U}<2>\mathrm{U} \quad[0.004554] \\
& \langle 1\rangle::=\mathrm{A}\langle 2>\mathrm{C}[0.004450] \\
& <1>::=\mathrm{A}<2>\mathrm{U}[0.111253] \\
& \langle 2\rangle::=\mathrm{C}\langle 3>\mathrm{C} \quad[0.000303] \\
& <2>::=\mathrm{C}<3>\mathrm{U} \quad[0.000378] \\
& <2>::=\mathrm{G}<3>\mathrm{C} \quad[0.412326] \\
& <2>::=\mathrm{G}<3>\mathrm{U} \quad[0.028631] \\
& <2>::=\mathrm{U}<3>\mathrm{C} \quad[0.000360] \\
& <2>::=\mathrm{U}<3>\mathrm{U} \quad[0.000650] \\
& <2\rangle::=\mathrm{A}<3>\mathrm{C} \quad[0.000545] \\
& <2\rangle::=A<3>\mathrm{U}[0.072210] \\
& <3\rangle::=\mathrm{C}<4>\mathrm{C} \quad[0.000303] \\
& \langle 3\rangle::=\mathrm{C}<4>\mathrm{U} \quad[0.000378] \\
& \langle 3\rangle::=\mathrm{G}\langle 4\rangle \mathrm{C} \quad[0.332287] \\
& \langle 3\rangle::=G<4>U \text { [0.061818] }
\end{aligned}
$$

$$
\begin{aligned}
& \langle 8\rangle::=\langle 9\rangle\langle 76\rangle \text { [1] } \\
& \langle 77\rangle::=\langle 26\rangle\langle 78\rangle \text { [1] } \\
& \langle 79\rangle::=\langle 39\rangle\langle 63\rangle \text { [1] } \\
& \langle 1\rangle::=\mathrm{C}<2>\mathrm{G} \text { [0.066512] } \\
& <1>::=\mathrm{C}<2>\mathrm{A} \quad[0.016078] \\
& <1>::=\mathrm{G}<2>\mathrm{G} \text { [0.000308] } \\
& <1>::=\mathrm{G}<2>\mathrm{A} \quad[0.000282] \\
& <1>::=U<2>G \quad[0.000947] \\
& <1>::=\mathrm{U}<2>\mathrm{A} \quad[0.075745] \\
& <1>::=\mathrm{A}<2>\mathrm{G}[0.000287] \\
& \langle 1\rangle::=\mathrm{A}<2>\mathrm{A}[0.000380] \\
& <2>::=\mathrm{C}<3>\mathrm{G}[0.380810] \\
& <2>::=\mathrm{C}<3>\mathrm{A} \quad[0.002413] \\
& <2>::=\mathrm{G}<3>\mathrm{G}[0.000308] \\
& <2>::=\mathrm{G}<3>\mathrm{A} \quad[0.000282] \\
& <2\rangle::=U<3>G \quad[0.012660] \\
& <2>::=\mathrm{U}<3>\mathrm{A} \quad[0.087458] \\
& <2>::=A<3>G \text { [0.000287] } \\
& \langle 2\rangle::=\mathrm{A}\langle 3\rangle \mathrm{A}[0.000380] \\
& \langle 3\rangle::=\mathrm{C}<4>\mathrm{G}[0.332006] \\
& \langle 3\rangle::=\mathrm{C}\langle 4\rangle \mathrm{A} \quad[0.004365] \\
& <3>::=\mathrm{G}<4>\mathrm{G}[0.000308] \\
& \langle 3\rangle::=\mathrm{G}\langle 4\rangle \mathrm{A}[0.000282]
\end{aligned}
$$




$$
\begin{aligned}
& <3>::=\mathrm{U}<4>\mathrm{C} \quad[0.000360] \\
& \langle 3\rangle::=U<4>\mathrm{U} \quad[0.002602] \\
& <3\rangle::=\mathrm{A}<4>\mathrm{C} \quad[0.000545] \\
& \langle 3\rangle::=\mathrm{A}<4>\mathrm{U}[0.121014] \\
& <4>::=\mathrm{C}<5>\mathrm{C}[0.002255] \\
& <4>::=\mathrm{C}<5>\mathrm{U}[0.002330] \\
& <4>::=\mathrm{G}<5>\mathrm{C}[0.330335] \\
& \langle 4\rangle::=G<5>U \text { [0.048152] } \\
& \langle 4\rangle::=\mathrm{U}\langle 5>\mathrm{C}[0.000360] \\
& <4>::=\mathrm{U}<5>\mathrm{U} \quad[0.000650] \\
& <4>::=A<5>C[0.002497] \\
& \langle 4>::=\mathrm{A}<5>\mathrm{U} \quad[0.134679] \\
& \langle 5\rangle::=C<6>C \quad[0.006159] \\
& <5\rangle::=\mathrm{C}<6>\mathrm{U}[0.002330] \\
& <5\rangle::=\mathrm{G}<6>\mathrm{C}[0.254200] \\
& <5\rangle::=\mathrm{G}\langle 6\rangle \mathrm{U} \quad[0.052057] \\
& \langle 5\rangle::=\mathrm{U}\langle 6\rangle \mathrm{C} \quad[0.000360] \\
& <5>::=U<6>U \text { [0.002602] } \\
& <5\rangle::=\mathrm{A}<6>\mathrm{C} \quad[0.002497] \\
& \langle 5\rangle::=\mathrm{A}\langle 6\rangle \mathrm{U}[0.226430] \\
& \langle 6\rangle::=\mathrm{C}\langle 7\rangle \mathrm{C}[0.000303] \\
& \langle 6\rangle::=\mathrm{C}\langle 7\rangle \mathrm{U}[0.000378] \\
& \langle 6\rangle::=\mathrm{G}\langle 7\rangle \mathrm{C} \quad[0.238582] \\
& \langle 6\rangle::=\mathrm{G}\langle 7>\mathrm{U}[0.032535] \\
& \langle 6\rangle::=\mathrm{U}<7>\mathrm{C}[0.000360] \\
& \langle 6\rangle::=\mathrm{U}\langle 7\rangle \mathrm{U}[0.014315] \\
& <6>::=\mathrm{A}<7>\mathrm{C}[0.000545] \\
& \langle 6\rangle::=\mathrm{A}\langle 7\rangle \mathrm{U}[0.179579] \\
& \langle 7\rangle::=\mathrm{C}<8>\mathrm{C}[0.000303] \\
& <7>::=\mathrm{C}<8>\mathrm{U}[0.000378] \\
& \langle 7\rangle::=\mathrm{G}<8>\mathrm{C}[0.373282] \\
& \langle 7\rangle::=\mathrm{G}<8>\mathrm{U}[0.032535]
\end{aligned}
$$

$$
\begin{aligned}
& \langle 3\rangle::=\mathrm{U}\langle 4>\mathrm{G} \quad[0.010708] \\
& \langle 3\rangle::=\mathrm{U}<4>\mathrm{A} \quad[0.130405] \\
& \langle 3\rangle::=\mathrm{A}\langle 4\rangle \mathrm{G}[0.000287] \\
& \langle 3\rangle::=\mathrm{A}\langle 4\rangle \mathrm{A}[0.002333] \\
& <4>::=\mathrm{C}<5>\mathrm{G} \quad[0.242207] \\
& \langle 4\rangle::=\mathrm{C}<5>\mathrm{A} \quad[0.004365] \\
& <4>::=\mathrm{G}<5>\mathrm{G}[0.000308] \\
& \langle 4\rangle::=\mathrm{G}\langle 5\rangle \mathrm{A}[0.000282] \\
& <4>::=U<5>G \quad[0.061464] \\
& <4>::=\mathrm{U}<5>\mathrm{A} \quad[0.169448] \\
& <4>::=\mathrm{A}<5>\mathrm{G}[0.000287] \\
& \langle 4\rangle::=\mathrm{A}\langle 5\rangle \mathrm{A}[0.000380] \\
& \langle 5\rangle::=\mathrm{C}<6>\mathrm{G} \quad[0.294916] \\
& \langle 5\rangle::=\mathrm{C}<6>\mathrm{A} \quad[0.000461] \\
& <5\rangle::=\mathrm{G}<6>\mathrm{G}[0.000308] \\
& \langle 5\rangle::=\mathrm{G}<6>\mathrm{A}[0.004187] \\
& \langle 5\rangle::=\mathrm{U}<6>\mathrm{G} \quad[0.024373] \\
& \langle 5\rangle::=\mathrm{U}\langle 6\rangle \mathrm{A} \quad[0.128453] \\
& \langle 5\rangle::=\mathrm{A}\langle 6\rangle \mathrm{G}[0.000287] \\
& \langle 5\rangle::=\mathrm{A}\langle 6\rangle \mathrm{A}[0.000380] \\
& \langle 6\rangle::=\mathrm{C}\langle 7>\mathrm{G} \quad[0.253920] \\
& \langle 6\rangle::=\mathrm{C}\langle 7>\mathrm{A} \quad[0.000461] \\
& \langle 6\rangle::=\mathrm{G}\langle 7>\mathrm{G}[0.000308] \\
& <6\rangle::=\mathrm{G}\langle 7>\mathrm{A}[0.000282] \\
& \langle 6\rangle::=U\langle 7>G \quad[0.053655] \\
& \langle 6\rangle::=\mathrm{U}\langle 7\rangle \mathrm{A} \quad[0.224109] \\
& \langle 6\rangle::=A<7>G[0.000287] \\
& \langle 6\rangle::=\mathrm{A}\langle 7\rangle \mathrm{A}[0.000380] \\
& \langle 7\rangle::=\mathrm{C}<8>\mathrm{G} \quad[0.029421] \\
& \langle 7\rangle::=\mathrm{C}<8>\mathrm{A} \quad[0.000461] \\
& <7>::=\mathrm{G}<8>\mathrm{G}[0.000308] \\
& \langle 7\rangle::=\mathrm{G}\langle 8>\mathrm{A} \quad[0.002235]
\end{aligned}
$$




$$
\begin{aligned}
& \langle 7\rangle::=\mathrm{U}<8>\mathrm{C} \quad[0.000360] \\
& <7>::=\mathrm{U}<8>\mathrm{U} \quad[0.000650] \\
& <7\rangle::=A<8>C \quad[0.000545] \\
& <7>::=\mathrm{A}<8>\mathrm{U} \text { [0.351369] } \\
& \langle 9\rangle::=\mathrm{C}\langle 10\rangle[0.000671] \\
& \langle 9\rangle::=U\langle 10\rangle \text { [0.963879] } \\
& \langle 10\rangle::=\mathrm{C}[0.038552] \\
& \langle 10\rangle::=\mathrm{U}[0.016880] \\
& \langle 11\rangle::=\mathrm{C}<12>\mathrm{C}[0.000303] \\
& <11>:=\mathrm{C}<12>\mathrm{U}[0.000378] \\
& <11>::=\mathrm{G}<12>\mathrm{C}[0.763715] \\
& \langle 11\rangle::=\mathrm{G}<12>\mathrm{U} \text { [0.122335] } \\
& <11>::=\mathrm{U}<12>\mathrm{C}[0.000360] \\
& <11>::=\mathrm{U}<12>\mathrm{U} \text { [0.002602] } \\
& <11>::=\mathrm{A}<12>\mathrm{C}[0.000545] \\
& \langle 11\rangle::=\mathrm{A}<12>\mathrm{U}[0.052688] \\
& <12\rangle::=\mathrm{C}<13>\mathrm{C}[0.000303] \\
& <12\rangle::=\mathrm{C}<13>\mathrm{U}[0.000378] \\
& \langle 12\rangle::=\mathrm{G}<13>\mathrm{C}[0.035558] \\
& <12>::=\mathrm{G}<13>\mathrm{U}[0.001300] \\
& \langle 12\rangle::=\mathrm{U}<13>\mathrm{C}[0.000360] \\
& \langle 12\rangle::=\mathrm{U}<13>\mathrm{U}[0.000650] \\
& \langle 12\rangle::=A<13\rangle \mathrm{C}[0.000545] \\
& \langle 12\rangle::=A<13>\mathrm{U} \text { [0.044879] } \\
& \langle 13\rangle::=\mathrm{C}<14>\mathrm{C}[0.000303] \\
& <13\rangle::=\mathrm{C}<14>\mathrm{U}[0.000378] \\
& <13>::=\mathrm{G}<14>\mathrm{C}[0.215157] \\
& <13\rangle::=G<14>\mathrm{U}[0.003253] \\
& \langle 13\rangle::=\mathrm{U}<14>\mathrm{C}[0.000360] \\
& \langle 13\rangle::=\mathrm{U}<14>\mathrm{U}[0.000650] \\
& \langle 13\rangle::=\mathrm{A}<14>\mathrm{C}[0.002497] \\
& \langle 13\rangle::=A<14>\mathrm{U}[0.062449]
\end{aligned}
$$

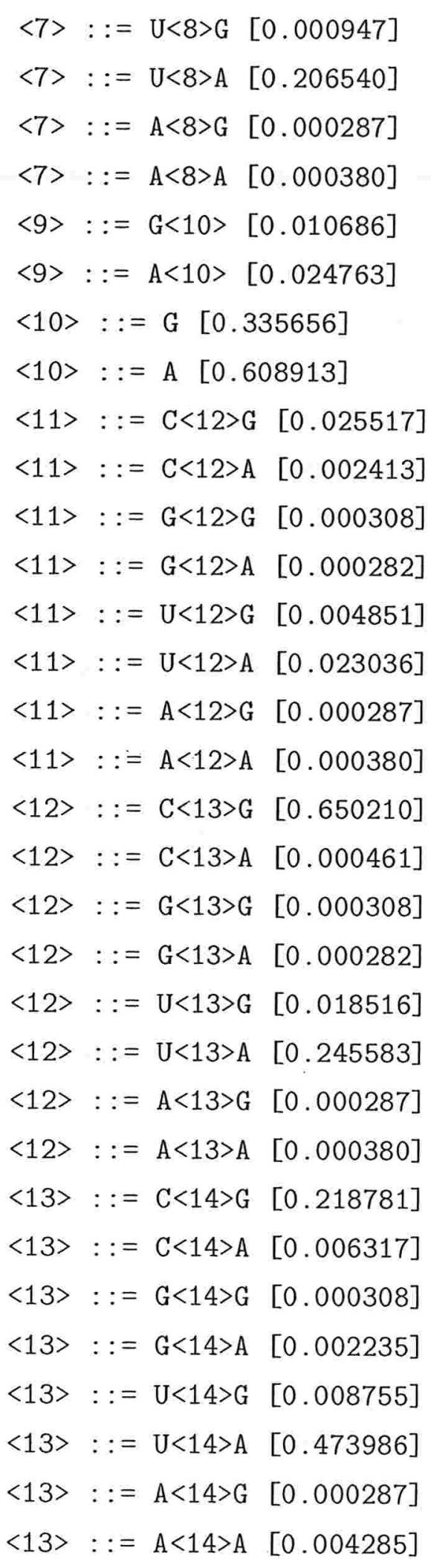




$$
\begin{aligned}
& <14>::=\mathrm{C}<15>\mathrm{C} \quad[0.004207] \\
& <14>::=C<15>\mathrm{U}[0.002330] \\
& <14>::=\mathrm{G}<15>\mathrm{C}[0.008227] \\
& <14>::=\mathrm{G}<15>\mathrm{U} \text { [0.014966] } \\
& <14>::=\mathrm{U}<15>\mathrm{C}[0.000360] \\
& <14>::=\mathrm{U}<15>\mathrm{U} \quad[0.068975] \\
& \langle 14\rangle::=A<15>C[0.004450] \\
& \langle 14>::=\mathrm{A}<15>\mathrm{U}[0.015597] \\
& \langle 15\rangle::=\mathrm{C}<81\rangle[0.004600] \\
& \langle 15\rangle::=\mathrm{U}\langle 81\rangle[0.004766] \\
& \langle 15\rangle::=\langle 16\rangle \text { [0.013649] } \\
& \langle 15\rangle::=\mathrm{G}\langle 16\rangle \text { [0.002578] } \\
& \langle 15\rangle::=A\langle 16\rangle \text { [0.962209] } \\
& \langle 16\rangle::=G<82\rangle[0.058356] \\
& \langle 16\rangle::=\mathrm{A}\langle 82\rangle[0.001870] \\
& \langle 16\rangle::=\mathrm{C}\langle 17\rangle[0.003357] \\
& \langle 16\rangle::=\mathrm{U}\langle 17\rangle[0.001734] \\
& \langle 17\rangle::=\mathrm{C}\langle 83\rangle[0.035436] \\
& \langle 17\rangle::=\mathrm{U}\langle 83\rangle[0.039975] \\
& \langle 17\rangle::=\langle 18\rangle \text { [0.005830] } \\
& \langle 17\rangle::=\mathrm{G}\langle 18\rangle \text { [0.036450] } \\
& \langle 17\rangle::=A\langle 18\rangle[0.053561] \\
& \langle 18\rangle::=G<84\rangle[0.000716] \\
& \langle 18\rangle::=A<84\rangle[0.002634] \\
& \langle 18\rangle::=\mathrm{C}\langle 19\rangle \text { [0.052808] } \\
& \langle 18\rangle::=\mathrm{U}\langle 19\rangle \text { [0.322187] } \\
& \langle 19\rangle::=\mathrm{C}\langle 85\rangle \text { [0.001171] } \\
& \langle 19\rangle::=U<85\rangle[0.003227] \\
& \langle 19\rangle::=\langle 20\rangle \text { [0.001485] } \\
& \langle 19\rangle::=\mathrm{G}\langle 20\rangle \text { [0.964033] } \\
& \langle 19\rangle::=\mathrm{A}\langle 20\rangle[0.024836] \\
& \langle 20\rangle::=\mathrm{G}\langle 86\rangle[0.226948]
\end{aligned}
$$

$$
\begin{aligned}
& \langle 14\rangle::=\mathrm{C}\langle 15>\mathrm{G} \quad[0.456945] \\
& \langle 14\rangle::=\mathrm{C}\langle 15\rangle \mathrm{A} \quad[0.004365] \\
& \langle 14>::=G<15>G \quad[0.002260] \\
& \langle 14\rangle::=\mathrm{G}<15>\mathrm{A} \quad[0.117412] \\
& \langle 14>::=U<15>G \quad[0.094651] \\
& \langle 14\rangle::=\mathrm{U}\langle 15>\mathrm{A} \quad[0.097219] \\
& \langle 14\rangle::=A<15>G \quad[0.006143] \\
& \langle 14\rangle::=\mathrm{A}\langle 15\rangle \mathrm{A}[0.101893] \\
& \langle 15\rangle::=\mathrm{G}\langle 81\rangle[0.000727] \\
& \langle 15\rangle::=A<81\rangle[0.007717] \\
& \langle 15\rangle::=\mathrm{C}\langle 16\rangle[0.000709] \\
& \langle 15\rangle::=\mathrm{U}\langle 16\rangle \quad[0.003044] \\
& \langle 16\rangle::=C<82\rangle[0.000684] \\
& \langle 16\rangle::=U\langle 82\rangle[0.001130] \\
& \langle 16\rangle::=\langle 17\rangle[0.003516] \\
& \langle 16\rangle::=G<17\rangle[0.670300] \\
& \langle 16\rangle::=A<17\rangle[0.259052] \\
& \langle 17\rangle::=\mathrm{G}\langle 83\rangle \text { [0.000778] } \\
& \langle 17\rangle::=A\langle 83\rangle[0.002145] \\
& \langle 17\rangle::=\mathrm{C}\langle 18\rangle \quad[0.169033] \\
& \langle 17\rangle::=\mathrm{U}\langle 18\rangle \text { [0.656792] } \\
& \langle 18\rangle::=\mathrm{C}\langle 84\rangle \text { [0.011019] } \\
& \langle 18\rangle::=\mathrm{U}\langle 84\rangle[0.023407] \\
& \langle 18\rangle::=\langle 19\rangle \text { [0.550425] } \\
& \langle 18\rangle::=\mathrm{G}\langle 19\rangle \text { [0.001300] } \\
& \langle 18\rangle::=A\langle 19\rangle[0.035503] \\
& \langle 19\rangle::=G<85\rangle \text { [0.000842] } \\
& \langle 19\rangle::=A<85\rangle[0.002010] \\
& \langle 19\rangle::=\mathrm{C}\langle 20\rangle \quad[0.000718] \\
& \langle 19\rangle::=\mathrm{U}\langle 20\rangle \text { [0.001679] } \\
& \langle 20\rangle::=\mathrm{C}\langle 86\rangle[0.003906] \\
& \langle 20\rangle::=\mathrm{U}\langle 86\rangle[0.000935]
\end{aligned}
$$




$$
\begin{aligned}
& \langle 20\rangle::=\mathrm{A}\langle 86\rangle[0.001296] \\
& <20\rangle::=\mathrm{C}<21\rangle[0.003233] \\
& <20\rangle::=\mathrm{U}\langle 21\rangle[0.001440] \\
& <21>::=\mathrm{C}<87>[0.058272] \\
& <21>::=\mathrm{U}<87>\text { [0.268719] } \\
& \langle 21\rangle::=\langle 22\rangle \text { [0.001129] } \\
& \langle 21\rangle::=\mathrm{G}<22>[0.063284] \\
& \langle 21\rangle::=\mathrm{A}<22\rangle \text { [0.035927] } \\
& \langle 22\rangle::=\text { G [0.060528] } \\
& \langle 22\rangle::=\text { A }[0.909958] \\
& \langle 26\rangle::=\text { G [0.453283] } \\
& \langle 26\rangle::=\text { A }[0.423500] \\
& <27>::=\mathrm{C}\langle 28>\mathrm{G} \quad[0.378858] \\
& <27>::=\mathrm{C}<28>\mathrm{A} \quad[0.006317] \\
& <27>::=\mathrm{G}<28>\mathrm{G}[0.000308] \\
& <27>::=\mathrm{G}<28>\mathrm{A} \quad[0.002235] \\
& <27>::=\mathrm{U}<28>\mathrm{G} \quad[0.045847] \\
& <27\rangle::=\mathrm{U}<28>\mathrm{A} \quad[0.284626] \\
& \langle 27\rangle::=\mathrm{A}\langle 28>\mathrm{G} \quad[0.002239] \\
& \langle 27\rangle::=\mathrm{A}<28>\mathrm{A} \quad[0.008189] \\
& \langle 28>::=\mathrm{C}<29>\mathrm{G}[0.367146] \\
& \langle 28\rangle::=\mathrm{C}<29>\mathrm{A} \quad[0.000461] \\
& \langle 28>::=\mathrm{G}<29>\mathrm{G}[0.000308] \\
& \langle 28>::=\mathrm{G}\langle 29>\mathrm{A} \quad[0.000282] \\
& \langle 28>::=U<29>\text { G }[0.018516] \\
& \langle 28\rangle::=\mathrm{U}\langle 29>\mathrm{A} \quad[0.317813] \\
& \langle 28\rangle::=\mathrm{A}\langle 29\rangle \mathrm{G}[0.000287] \\
& \langle 28\rangle::=\mathrm{A}\langle 29\rangle \mathrm{A} \quad[0.000380] \\
& \langle 29\rangle::=\mathrm{C}\langle 30\rangle \mathrm{G}[0.173881] \\
& \langle 29\rangle::=\mathrm{C}\langle 30>\mathrm{A} \quad[0.000461] \\
& \langle 29\rangle::=\mathrm{G}<30>\mathrm{G}[0.002260] \\
& <29>::=\mathrm{G}<30>\mathrm{A}[0.000282]
\end{aligned}
$$

$$
\begin{aligned}
& \langle 20\rangle::=\langle 21\rangle[0.001464] \\
& \langle 20\rangle::=\mathrm{G}\langle 21\rangle \text { [0.756208] } \\
& \langle 20\rangle::=\mathrm{A}\langle 21\rangle[0.004570] \\
& \langle 21\rangle::=\mathrm{G}\langle 87\rangle[0.001425] \\
& \langle 21\rangle::=\mathrm{A}\langle 87\rangle[0.004610] \\
& \langle 21\rangle::=\mathrm{C}\langle 22\rangle \quad[0.031293] \\
& \langle 21\rangle::=\mathrm{U}\langle 22\rangle[0.535341] \\
& \langle 22\rangle::=\text { C [0.008646] } \\
& \langle 22\rangle::=U[0.020867] \\
& \langle 26\rangle::=\text { C }[0.032570] \\
& \langle 26\rangle::=\mathrm{U}[0.090646] \\
& \langle 27\rangle::=\mathrm{C}\langle 28>\mathrm{C}[0.004207] \\
& \langle 27\rangle::=\mathrm{C}<28>\mathrm{U}[0.008186] \\
& <27>::=\mathrm{G}<28>\mathrm{C} \quad[0.074601] \\
& \langle 27\rangle::=\mathrm{G}\langle 28>\mathrm{U}[0.063770] \\
& \langle 27\rangle::=\mathrm{U}\langle 28>\mathrm{C}[0.000360] \\
& \langle 27\rangle::=U<28>U[0.012362] \\
& \langle 27\rangle::=\mathrm{A}\langle 28\rangle \mathrm{C}[0.000545] \\
& \langle 27\rangle::=\mathrm{A}\langle 28>\mathrm{U}[0.107348] \\
& \langle 28\rangle::=\mathrm{C}\langle 29\rangle \mathrm{C}[0.000303] \\
& \langle 28\rangle::=\mathrm{C}<29>\mathrm{U} \quad[0.004282] \\
& \langle 28\rangle::=\mathrm{G}\langle 29>\mathrm{C}[0.090218] \\
& <28>::=\mathrm{G}<29>\mathrm{U} \quad[0.014966] \\
& \langle 28\rangle::=\mathrm{U}\langle 29>\mathrm{C} \quad[0.000360] \\
& <28>::=\mathrm{U}<29>\mathrm{U} \quad[0.006506] \\
& \langle 28\rangle::=A<29\rangle \mathrm{C}[0.000545] \\
& \langle 28\rangle::=\mathrm{A}\langle 29\rangle \mathrm{U}[0.177627] \\
& <29\rangle::=\mathrm{C}<30>\mathrm{C}[0.000303] \\
& \langle 29\rangle::=\mathrm{C}<30>\mathrm{U}[0.000378] \\
& <29>::=\mathrm{G}<30>\mathrm{C} \quad[0.396708] \\
& <29>::=\mathrm{G}<30>\mathrm{U}[0.007157] \\
& <29>::=\mathrm{U}<30>\mathrm{C}[0.000360]
\end{aligned}
$$




$$
\begin{aligned}
& <29>::=U<30>G \quad[0.002899] \\
& <29>::=\mathrm{U}<30>\mathrm{A} \quad[0.208492] \\
& <29>::=A<30>G \quad[0.000287] \\
& <29\rangle::=\mathrm{A}<30>\mathrm{A} \quad[0.002333] \\
& <30\rangle::=\mathrm{C}<31>\mathrm{G} \quad[0.209020] \\
& <30\rangle::=\mathrm{C}<31>\mathrm{A} \quad[0.002413] \\
& <30>::=\mathrm{G}<31>\mathrm{G}[0.000308] \\
& \langle 30\rangle::=\mathrm{G}<31>\mathrm{A} \quad[0.000282] \\
& <30\rangle::=\mathrm{U}<31>\mathrm{G} \quad[0.012660] \\
& <30\rangle::=\mathrm{U}\langle 31>\mathrm{A} \quad[0.021084] \\
& <30>::=A<31>G \quad[0.000287] \\
& <30\rangle::=\mathrm{A}<31>\mathrm{A}[0.000380] \\
& <31>::=\mathrm{C}<32>\mathrm{G}[0.267585] \\
& <31>::=\mathrm{C}<32>\mathrm{A} \quad[0.000461] \\
& <31>::=\mathrm{G}<32>\mathrm{G}[0.000308] \\
& <31>::=\mathrm{G}<32>\mathrm{A}[0.000282] \\
& <31>::=\mathrm{U}<32>\mathrm{G} \quad[0.032181] \\
& <31>::=\mathrm{U}<32>\mathrm{A} \quad[0.097218] \\
& <31>::=A<32>G \quad[0.000287] \\
& <31>::=\mathrm{A}<32>\mathrm{A}[0.000380] \\
& \langle 32\rangle::=\mathrm{G}\langle 33\rangle[0.002711] \\
& \langle 32\rangle::=\mathrm{A}\langle 33\rangle[0.020776] \\
& \langle 33\rangle::=\mathrm{G}\langle 34>[0.000718] \\
& \langle 33\rangle::=A\langle 34\rangle[0.000839] \\
& \langle 34\rangle::=\mathrm{G}\langle 35\rangle \text { [0.331669] } \\
& \langle 34\rangle::=\mathrm{A}\langle 35\rangle[0.074605] \\
& \langle 35\rangle::=G\langle 36\rangle[0.220023] \\
& \langle 35\rangle::=\mathrm{A}\langle 36\rangle[0.313848] \\
& \langle 36\rangle::=G<37\rangle[0.226004] \\
& \langle 36\rangle::=\mathrm{A}\langle 37\rangle[0.271980] \\
& \langle 37\rangle::=G<38\rangle[0.237966] \\
& \langle 37\rangle::=A<38\rangle[0.758438]
\end{aligned}
$$

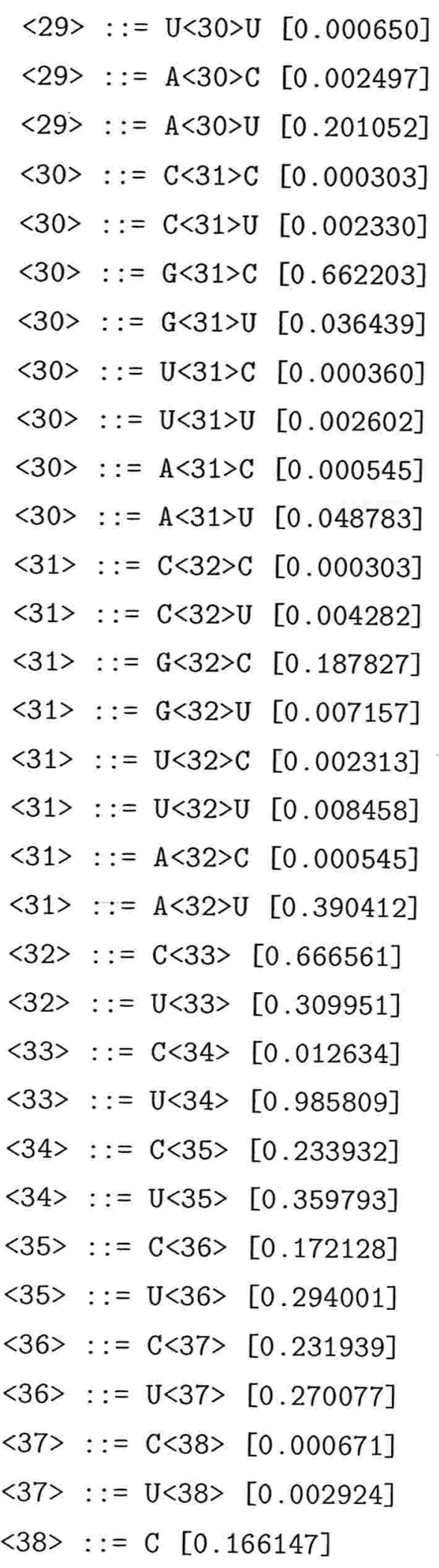




$$
\begin{aligned}
& \langle 38\rangle::=\text { G [0.012680] } \\
& \langle 38\rangle::=\text { A [0.698628] } \\
& \langle 39\rangle::=G\langle 90\rangle \text { [0.000752] } \\
& \langle 39\rangle::=A\langle 90\rangle[0.000881] \\
& \langle 39\rangle::=\mathrm{C}\langle 40\rangle \text { [0.139147] } \\
& \langle 39\rangle::=\mathrm{U}\langle 40\rangle \text { [0.180513] } \\
& \langle 40\rangle::=\mathrm{C}\langle 91\rangle[0.000712] \\
& \langle 40\rangle::=\mathrm{U}\langle 91\rangle[0.001084] \\
& \langle 40\rangle::=\langle 41\rangle \text { [0.976065] } \\
& \langle 40\rangle::=\mathrm{G}\langle 41\rangle[0.001302] \\
& \langle 40\rangle::=A<41\rangle[0.014348] \\
& <41\rangle::=\mathrm{G}<92>\text { [0.000977] } \\
& \langle 41\rangle::=\mathrm{A}\langle 92\rangle \text { [0.001030] } \\
& \langle 41\rangle::=\mathrm{C}\langle 42\rangle[0.003038] \\
& \langle 41\rangle::=\mathrm{U}\langle 42\rangle \text { [0.001435] } \\
& \langle 42\rangle::=\mathrm{C}\langle 93\rangle \text { [0.001003] } \\
& \langle 42\rangle::=\mathrm{U}\langle 93\rangle \text { [0.003357] } \\
& \langle 42\rangle::=\langle 43\rangle \text { [0.004953] } \\
& \langle 42\rangle::=G\langle 43\rangle \text { [0.556403] } \\
& \langle 42\rangle::=A\langle 43\rangle[0.163605] \\
& \langle 43\rangle::=G<94\rangle \text { [0.002509] } \\
& \langle 43\rangle::=\mathrm{A}\langle 94\rangle[0.008110] \\
& \langle 43\rangle::=\mathrm{C}\langle 44>[0.008442] \\
& \langle 43\rangle::=\mathrm{U}\langle 44>[0.060786] \\
& \langle 44\rangle::=\mathrm{C}\langle 95\rangle[0.004842] \\
& \langle 44\rangle::=\mathrm{U}\langle 95\rangle[0.010156] \\
& \langle 44\rangle::=\langle 45\rangle[0.975330] \\
& \langle 44\rangle::=\mathrm{G}\langle 45\rangle \text { [0.001113] } \\
& \langle 44\rangle::=A\langle 45\rangle[0.001284] \\
& \langle 45\rangle::=G\langle 96\rangle[0.027950] \\
& \langle 45\rangle::=A\langle 96\rangle[0.001831] \\
& \langle 45\rangle::=\mathrm{C}\langle 46\rangle[0.063857]
\end{aligned}
$$

$$
\begin{aligned}
& \langle 38\rangle::=\mathrm{U}[0.122545] \\
& \langle 39\rangle::=\mathrm{C}\langle 90\rangle[0.003007] \\
& \langle 39\rangle::=\mathrm{U}\langle 90\rangle[0.047358 \\
& \langle 39\rangle::=\langle 40\rangle \text { [0.007089] } \\
& \langle 39\rangle::=G\langle 40\rangle \text { [0.182203] } \\
& \langle 39\rangle::=A\langle 40\rangle[0.439051] \\
& \langle 40\rangle::=G\langle 91\rangle[0.000978] \\
& \langle 40\rangle::=A\langle 91\rangle[0.001035] \\
& \langle 40\rangle::=\mathrm{C}\langle 41\rangle[0.003034] \\
& \langle 40\rangle::=\mathrm{U}\langle 41\rangle[0.001442] \\
& \langle 41\rangle::=\mathrm{C}\langle 92\rangle \quad[0.000713] \\
& \langle 41\rangle::=\mathrm{U}\langle 92\rangle \quad[0.001088] \\
& \langle 41\rangle::=\langle 42\rangle \text { [0.977563] } \\
& \langle 41\rangle::=\mathrm{G}<42\rangle \text { [0.001294] } \\
& \langle 41\rangle::=\mathrm{A}\langle 42\rangle \text { [0.012862] } \\
& \langle 42\rangle::=\mathrm{G}\langle 93\rangle \text { [0.053461] } \\
& \langle 42\rangle::=\mathrm{A}\langle 93\rangle \text { [0.011759] } \\
& \langle 42\rangle::=\mathrm{C}\langle 43\rangle \text { [0.026339] } \\
& \langle 42\rangle::=\mathrm{U}\langle 43\rangle \quad[0.179120] \\
& \langle 43\rangle::=\mathrm{C}\langle 94\rangle \quad[0.003156] \\
& \langle 43\rangle::=\mathrm{U}\langle 94\rangle[0.010361] \\
& \langle 43\rangle::=\langle 44\rangle \text { [0.002968] } \\
& \langle 43\rangle::=G\langle 44\rangle \quad[0.663010] \\
& \langle 43\rangle::=\mathrm{A}\langle 44\rangle \text { [0.240658] } \\
& \langle 44\rangle::=G\langle 95\rangle \text { [0.000898] } \\
& \langle 44\rangle::=A\langle 95\rangle[0.000944] \\
& \langle 44\rangle::=\mathrm{C}\langle 45\rangle[0.002594] \\
& \langle 44\rangle::=\mathrm{U}\langle 45\rangle \quad[0.002839] \\
& \langle 45\rangle::=\mathrm{C}\langle 96\rangle \text { [0.010055] } \\
& \langle 45\rangle::=\mathrm{U}\langle 96\rangle[0.002756] \\
& \langle 45\rangle::=\langle 46\rangle \text { [0.311847] } \\
& \langle 45\rangle::=G\langle 46\rangle[0.006889]
\end{aligned}
$$




$$
\begin{aligned}
& \langle 45\rangle::=\mathrm{U}\langle 46\rangle \quad[0.566127] \\
& \langle 46\rangle::=\text { C [0.724378] } \\
& \langle 46\rangle::=U[0.234192] \\
& \langle 63\rangle::=\mathrm{C}<64>\mathrm{C} \quad[0.000303] \\
& <63\rangle::=\mathrm{C}<64>\mathrm{U}[0.000378] \\
& <63\rangle::=\mathrm{G}<64>\mathrm{C} \quad[0.383043] \\
& \langle 63\rangle::=\mathrm{G}<64>\mathrm{U}[0.143809] \\
& <63\rangle::=U<64>C[0.004265] \\
& <63\rangle::=U<64>\mathrm{U}[0.004554] \\
& <63\rangle::=\mathrm{A}<64>\mathrm{C}[0.000545] \\
& \langle 63\rangle::=A<64>U[0.203004] \\
& <64\rangle::=\mathrm{C}<65>\mathrm{C}[0.002255] \\
& \langle 64\rangle::=\mathrm{C}<65>\mathrm{U}[0.002330] \\
& <64>::=G<65>C \text { [0.129262] } \\
& <64>::=\mathrm{G}<65>\mathrm{U}[0.057913] \\
& \langle 64\rangle::=\mathrm{U}<65>\mathrm{C}[0.004265] \\
& \langle 64\rangle::=U<65>U \text { [0.012362] } \\
& \langle 64\rangle::=\mathrm{A}<65\rangle \mathrm{C}[0.002497] \\
& \langle 64\rangle::=\mathrm{A}\langle 65\rangle \mathrm{U}[0.134679] \\
& \langle 65\rangle::=\mathrm{C}<66>\mathrm{C} \quad[0.000303] \\
& \langle 65\rangle::=\mathrm{C}<66>\mathrm{U} \quad[0.002330] \\
& \langle 65\rangle::=\mathrm{G}\langle 66\rangle \mathrm{C}[0.416230] \\
& \langle 65\rangle::=\mathrm{G}<66>\mathrm{U}[0.036439] \\
& <65\rangle::=\mathrm{U}<66>\mathrm{C} \quad[0.000360] \\
& \langle 65\rangle::=U<66>U \text { [0.004554] } \\
& \langle 65\rangle::=\mathrm{A}\langle 66\rangle \mathrm{C}[0.002497] \\
& <65\rangle::=\mathrm{A}<66>\mathrm{U} \quad[0.222526] \\
& \langle 66\rangle::=\mathrm{C}<67>\mathrm{C}[0.000303] \\
& <66>::=\mathrm{C}<67>\mathrm{U} \quad[0.002330] \\
& \langle 66\rangle::=\mathrm{G}\langle 67\rangle \mathrm{C} \quad[0.794950] \\
& \langle 66\rangle::=\mathrm{G}<67>\mathrm{U} \text { [0.007157] } \\
& \langle 66\rangle::=U<67>C[0.000360]
\end{aligned}
$$

$$
\begin{aligned}
& \langle 45\rangle::=A\langle 46\rangle[0.008688] \\
& \langle 46\rangle::=\text { G [0.008692] } \\
& \langle 46\rangle::=\text { A }[0.032738] \\
& <63\rangle::=\mathrm{C}<64>\mathrm{G}[0.224638] \\
& <63\rangle::=\mathrm{C}<64>\mathrm{A} \quad[0.004365] \\
& <63\rangle::=\mathrm{G}<64>\mathrm{G}[0.000308] \\
& \langle 63\rangle::=\mathrm{G}\langle 64>\mathrm{A}[0.000282] \\
& <63\rangle::=U<64>G \quad[0.010708] \\
& <63\rangle::=\mathrm{U}<64>\mathrm{A} \quad[0.015228] \\
& \langle 63\rangle::=\mathrm{A}\langle 64\rangle \mathrm{G}[0.002239] \\
& \langle 63\rangle::=\mathrm{A}\langle 64\rangle \mathrm{A}[0.002333] \\
& \langle 64>::=\mathrm{C}<65>\mathrm{G} \quad[0.365193] \\
& \langle 64\rangle::=\mathrm{C}\langle 65>\mathrm{A} \quad[0.000461] \\
& \langle 64\rangle::=G<65>G[0.000308] \\
& \langle 64\rangle::=\mathrm{G}\langle 65\rangle \mathrm{A}[0.000282] \\
& <64>::=U<65>G \quad[0.038038] \\
& <64>::=\mathrm{U}<65>\mathrm{A} \quad[0.249487] \\
& \langle 64\rangle::=A<65>G \text { [0.000287] } \\
& \langle 64\rangle::=\mathrm{A}\langle 65\rangle \mathrm{A}[0.000380] \\
& \langle 65\rangle::=\mathrm{C}\langle 66\rangle \mathrm{G}[0.166073] \\
& \langle 65\rangle::=\mathrm{C}\langle 66\rangle \mathrm{A} \quad[0.000461] \\
& \langle 65\rangle::=G\langle 66\rangle G[0.002260] \\
& \langle 65\rangle::=\mathrm{G}\langle 66\rangle \mathrm{A} \quad[0.000282] \\
& \langle 65\rangle::=U<66>\mathrm{G} \quad[0.043894] \\
& \langle 65\rangle::=\mathrm{U}\langle 66\rangle \mathrm{A} \quad[0.101123] \\
& \langle 65\rangle::=\mathrm{A}\langle 66\rangle \mathrm{G}[0.000287] \\
& \langle 65\rangle::=A<66\rangle \mathrm{A} \quad[0.000380] \\
& \langle 66>::=\mathrm{C}\langle 67>\mathrm{G}[0.015756] \\
& \langle 66\rangle::=\mathrm{C}\langle 67>\mathrm{A} \quad[0.000461] \\
& \langle 66\rangle::=\mathrm{G}\langle 67\rangle \mathrm{G}[0.000308] \\
& \langle 66\rangle::=\mathrm{G}\langle 67\rangle \mathrm{A}[0.000282] \\
& \langle 66\rangle::=\mathrm{U}<67>\mathrm{G} \quad[0.002899]
\end{aligned}
$$




$$
\begin{aligned}
& \langle 66\rangle::=\mathrm{U}<67>\mathrm{U} \quad[0.000650] \\
& \langle 66\rangle::=A<67\rangle \mathrm{C}[0.004450] \\
& \langle 66\rangle::=\mathrm{A}\langle 67\rangle \mathrm{U}[0.144440] \\
& <67\rangle::=\mathrm{C}<68>\mathrm{C}[0.000303] \\
& \langle 67\rangle::=\mathrm{C}<68>\mathrm{U}[0.000378] \\
& \langle 67\rangle::=\mathrm{G}<68>\mathrm{C}[0.955027] \\
& \langle 67\rangle::=\mathrm{G}<68>\mathrm{U} \text { [0.005205] } \\
& \langle 67\rangle::=\mathrm{U}<68>\mathrm{C} \quad[0.000360] \\
& \langle 67\rangle::=U<68>\mathrm{U}[0.000650] \\
& \langle 67\rangle::=\mathrm{A}\langle 68>\mathrm{C}[0.004450] \\
& \langle 67\rangle::=\mathrm{A}\langle 68>\mathrm{U}[0.023405] \\
& \langle 68\rangle::=\mathrm{C}\langle 69\rangle[0.002665] \\
& \langle 68\rangle::=U\langle 69\rangle[0.963879] \\
& \langle 69\rangle::=\mathrm{C}\langle 70\rangle \text { [0.006653] } \\
& \langle 69\rangle::=U\langle 70\rangle \text { [0.971854] } \\
& \langle 70\rangle::=\mathrm{C}\langle 71\rangle[0.979569] \\
& \langle 70\rangle::=\mathrm{U}\langle 71\rangle[0.008905] \\
& \langle 71\rangle::=\mathrm{C}\langle 72\rangle[0.002665] \\
& \langle 71\rangle::=\mathrm{U}\langle 72\rangle[0.000931] \\
& \langle 72\rangle::=\mathrm{C}\langle 73\rangle[0.002665] \\
& \langle 72\rangle::=\mathrm{U}\langle 73\rangle[0.000931] \\
& \langle 73\rangle::=C<74\rangle[0.044532] \\
& \langle 73\rangle::=\mathrm{U}\langle 74\rangle[0.242166] \\
& \langle 74\rangle::=\text { C }[0.138236] \\
& \langle 74\rangle::=\text { U [0.816346] } \\
& \langle 75\rangle::=\text { C }[0.052507] \\
& \langle 75\rangle::=U[0.102608] \\
& \langle 81\rangle::=\mathrm{C}\langle 81\rangle[0.029213] \\
& <81>::=\mathrm{U}<81>[0.041903] \\
& \langle 81\rangle::=\mathrm{C}\langle 16\rangle[0.029291] \\
& \langle 81\rangle::=\mathrm{U}\langle 16\rangle[0.282733] \\
& \langle 82\rangle::=C<82>[0.069027]
\end{aligned}
$$

$$
\begin{aligned}
& \langle 66\rangle::=\mathrm{U}\langle 67>\mathrm{A} \quad[0.024988] \\
& \langle 66\rangle::=\mathrm{A}\langle 67\rangle \mathrm{G}[0.000287] \\
& \langle 66\rangle::=\mathrm{A}\langle 67\rangle \mathrm{A}[0.000380] \\
& \langle 67\rangle::=\mathrm{C}\langle 68>\mathrm{G}[0.004043] \\
& \langle 67\rangle::=\mathrm{C}\langle 68>\mathrm{A} \quad[0.000461] \\
& \langle 67\rangle::=\mathrm{G}\langle 68\rangle \mathrm{G}[0.000308] \\
& \langle 67\rangle::=\mathrm{G}\langle 68>\mathrm{A} \quad[0.000282] \\
& <67>::=\mathrm{U}<68>\mathrm{G} \quad[0.000947] \\
& \langle 67\rangle::=\mathrm{U}\langle 68>\mathrm{A} \quad[0.003515] \\
& \langle 67\rangle::=\mathrm{A}\langle 68>\mathrm{G}[0.000287] \\
& \langle 67\rangle::=\mathrm{A}\langle 68\rangle \mathrm{A}[0.000380] \\
& \langle 68\rangle::=\mathrm{G}\langle 69\rangle \quad[0.000718] \\
& \langle 68\rangle::=A\langle 69\rangle[0.032738] \\
& \langle 69\rangle::=G\langle 70\rangle[0.020654] \\
& \langle 69\rangle::=\mathrm{A}\langle 70\rangle[0.000839] \\
& \langle 70\rangle::=\mathrm{G}\langle 71\rangle[0.000718] \\
& \langle 70\rangle::=\mathrm{A}\langle 71\rangle[0.010808] \\
& \langle 71\rangle::=\mathrm{G}\langle 72\rangle \quad[0.608791] \\
& \langle 71\rangle::=A\langle 72\rangle[0.387613] \\
& \langle 72\rangle::=\mathrm{G}\langle 73\rangle[0.000718] \\
& \langle 72\rangle::=\mathrm{A}\langle 73\rangle[0.995687] \\
& \langle 73\rangle::=\mathrm{G}\langle 74\rangle \text { [0.224010] } \\
& \langle 73\rangle::=\mathrm{A}\langle 74\rangle[0.489291] \\
& \langle 74\rangle::=\text { G [0.008692] } \\
& \langle 74\rangle::=\text { A }[0.036725] \\
& \langle 75\rangle::=\text { G [0.243947] } \\
& \langle 75\rangle::=\mathrm{A}[0.600937] \\
& \langle 81\rangle::=G<81\rangle \quad[0.031543] \\
& \langle 81\rangle::=\mathrm{A}\langle 81\rangle \text { [0.119663] } \\
& \langle 81\rangle::=\mathrm{G}\langle 16\rangle \text { [0.034434] } \\
& \langle 81\rangle::=\mathrm{A}\langle 16\rangle \quad[0.431220] \\
& \langle 82\rangle::=G<82\rangle[0.009900]
\end{aligned}
$$




$$
\begin{aligned}
& <82>::=\mathrm{U}<82>[0.022805] \\
& \langle 82\rangle::=\mathrm{C}\langle 17\rangle[0.723150] \\
& \langle 82\rangle::=\mathrm{U}\langle 17>[0.095479] \\
& \langle 83\rangle::=\mathrm{C}\langle 83\rangle \text { [0.029567] } \\
& \langle 83\rangle::=U\langle 83\rangle \text { [0.024856] } \\
& \langle 83\rangle::=\mathrm{C}\langle 18\rangle \text { [0.658858] } \\
& \langle 83\rangle::=\mathrm{U}\langle 18\rangle[0.220064] \\
& <84>::=\mathrm{C}<84>\text { [0.016460] } \\
& <84>::=U<84>[0.023082] \\
& \langle 84\rangle::=\mathrm{C}\langle 19\rangle[0.579722] \\
& \langle 84\rangle::=\mathrm{U}\langle 19\rangle \quad[0.235993] \\
& \langle 85\rangle::=\mathrm{C}\langle 85\rangle \text { [0.065638] } \\
& \langle 85\rangle::=\mathrm{U}\langle 85\rangle \quad[0.103787] \\
& \langle 85\rangle::=\mathrm{C}\langle 20\rangle[0.066065] \\
& \langle 85\rangle::=\mathrm{U}\langle 20\rangle[0.200870] \\
& \langle 86\rangle::=\mathrm{C}\langle 86\rangle[0.019532] \\
& \langle 86\rangle::=\mathrm{U}\langle 86\rangle \quad[0.011943] \\
& \langle 86\rangle::=\mathrm{C}\langle 21\rangle[0.197352] \\
& \langle 86\rangle::=\mathrm{U}\langle 21\rangle \text { [0.492268] } \\
& \langle 87\rangle::=\mathrm{C}<87\rangle[0.070226] \\
& \langle 87\rangle::=\mathrm{U}\langle 87\rangle[0.013935] \\
& \langle 87\rangle::=C<22>[0.101778] \\
& <87>::=\mathrm{U}<22>[0.491867] \\
& \langle 90\rangle::=\mathrm{C}\langle 90\rangle \quad[0.321271] \\
& \langle 90\rangle::=U\langle 90\rangle[0.227611] \\
& \langle 90\rangle::=\mathrm{C}\langle 40\rangle[0.003308] \\
& \langle 90\rangle::=\mathrm{U}\langle 40\rangle[0.003828] \\
& \langle 91\rangle::=\mathrm{C}\langle 91\rangle \text { [0.113235] } \\
& \langle 91\rangle::=\mathrm{U}\langle 91\rangle[0.151131] \\
& \langle 91\rangle::=\mathrm{C}\langle 41\rangle \text { [0.100018] } \\
& \langle 91>::=\mathrm{U}\langle 41\rangle \text { [0.127369] } \\
& \langle 92\rangle::=C<92\rangle[0.112514]
\end{aligned}
$$

$$
\begin{aligned}
& \langle 82\rangle::=A<82\rangle[0.044885] \\
& \langle 82\rangle::=G\langle 17\rangle[0.012220] \\
& \langle 82\rangle::=\mathrm{A}\langle 17\rangle[0.022534] \\
& \langle 83\rangle::=G\langle 83\rangle[0.008472] \\
& \langle 83\rangle::=A\langle 83\rangle[0.011430] \\
& \langle 83\rangle::=\mathrm{G}\langle 18\rangle[0.010576] \\
& \langle 83\rangle::=A\langle 18\rangle \text { [0.036177] } \\
& \langle 84\rangle::=G\langle 84\rangle[0.017457] \\
& \langle 84\rangle::=\mathrm{A}\langle 84\rangle[0.020501] \\
& \langle 84\rangle::=\mathrm{G}\langle 19\rangle[0.036755] \\
& \langle 84\rangle::=A\langle 19\rangle[0.070030] \\
& \langle 85\rangle::=\mathrm{G}\langle 85\rangle \text { [0.083086] } \\
& \langle 85\rangle::=A\langle 85\rangle[0.094498] \\
& \langle 85\rangle::=G\langle 20\rangle \text { [0.264483] } \\
& \langle 85\rangle::=A\langle 20\rangle[0.121572] \\
& \langle 86\rangle::=G<86\rangle[0.002946] \\
& \langle 86\rangle::=A\langle 86\rangle[0.022555] \\
& \langle 86\rangle::=G\langle 21\rangle[0.008580] \\
& \langle 86\rangle::=A<21\rangle[0.244825] \\
& \langle 87\rangle::=\mathrm{G}\langle 87\rangle[0.001941] \\
& \langle 87\rangle::=\mathrm{A}\langle 87\rangle[0.010024] \\
& <87>::=G<22>[0.090795] \\
& \langle 87\rangle::=A<22\rangle[0.219434] \\
& \langle 90\rangle::=G\langle 90\rangle \text { [0.152056] } \\
& \langle 90\rangle::=A\langle 90\rangle[0.165586] \\
& \langle 90\rangle::=G\langle 40\rangle[0.115297] \\
& \langle 90\rangle::=A\langle 40\rangle[0.011043] \\
& \langle 91\rangle::=\mathrm{G}\langle 91\rangle \text { [0.119579] } \\
& \langle 91\rangle::=A\langle 91\rangle[0.141788] \\
& \langle 91\rangle::=\mathrm{G}\langle 41\rangle[0.109669] \\
& \langle 91\rangle::=A<41\rangle[0.137210] \\
& \langle 92>::=\mathrm{G}\langle 92>[0.119947]
\end{aligned}
$$




$$
\begin{aligned}
& \langle 92\rangle::=\mathrm{U}\langle 92\rangle[0.150505] \quad\langle 92\rangle::=\mathrm{A}\langle 92\rangle[0.142353] \\
& \langle 92\rangle::=\mathrm{C}\langle 42\rangle[0.100392] \quad\langle 92\rangle::=\mathrm{G}\langle 42\rangle[0.109585] \\
& \langle 92\rangle::=\mathrm{U}\langle 42\rangle[0.127151] \quad\langle 92\rangle::=\mathrm{A}\langle 42\rangle[0.137553] \\
& \langle 93\rangle::=\mathrm{C}\langle 93\rangle[0.146966] \quad\langle 93\rangle::=\mathrm{G}\langle 93\rangle[0.179996] \\
& \langle 93\rangle::=\mathrm{U}\langle 93\rangle[0.258171] \quad\langle 93\rangle::=\mathrm{A}\langle 93\rangle[0.301805] \\
& \langle 93\rangle::=\mathrm{C}\langle 43\rangle[0.064284] \quad\langle 93\rangle::=\mathrm{G}\langle 43\rangle[0.001423] \\
& \langle 93\rangle::=\mathrm{U}\langle 43\rangle[0.045531] \quad\langle 93\rangle::=\mathrm{A}\langle 43\rangle[0.001823] \\
& \langle 94\rangle::=\mathrm{C}\langle 94\rangle[0.130862] \quad\langle 94\rangle::=\mathrm{G}\langle 94\rangle[0.148002] \\
& \langle 94\rangle::=\mathrm{U}\langle 94\rangle[0.448381] \quad\langle 94\rangle::=\mathrm{A}\langle 94\rangle[0.155554] \\
& \langle 94\rangle::=\mathrm{C}\langle 44>[0.008299] \quad\langle 94\rangle::=\mathrm{G}\langle 44\rangle[0.005484] \\
& \langle 94>::=\mathrm{U}\langle 44>[0.014983] \quad\langle 94>::=\mathrm{A}\langle 44\rangle[0.088435] \\
& \langle 95\rangle::=\mathrm{C}\langle 95\rangle[0.286602] \quad\langle 95\rangle::=\mathrm{G}\langle 95\rangle[0.296465] \\
& \langle 95\rangle::=\mathrm{U}\langle 95\rangle[0.043000] \quad\langle 95\rangle::=\mathrm{A}\langle 95\rangle[0.253582] \\
& \langle 95\rangle::=\mathrm{C}\langle 45\rangle[0.034294] \quad\langle 95\rangle::=\mathrm{G}\langle 45\rangle[0.037659] \\
& \langle 95\rangle::=\mathrm{U}\langle 45\rangle[0.039676] \quad\langle 95\rangle::=\mathrm{A}\langle 45\rangle[0.008721] \\
& \langle 96\rangle::=\mathrm{C}\langle 96\rangle[0.401537] \quad\langle 96\rangle::=\mathrm{G}\langle 96\rangle[0.143528] \\
& \langle 96\rangle::=\mathrm{U}\langle 96\rangle[0.255206] \quad\langle 96\rangle::=\mathrm{A}\langle 96\rangle[0.069289] \\
& \langle 96\rangle::=\mathrm{C}\langle 46\rangle[0.003339] \quad\langle 96\rangle::=\mathrm{G}\langle 46\rangle[0.104709] \\
& \langle 96\rangle::=\mathrm{U}\langle 46\rangle[0.014544] \quad\langle 96\rangle::=\mathrm{A}\langle 46\rangle[0.007847]
\end{aligned}
$$


; 


\section{Referências Bibliográficas}

[AB92] M. Anthony and N. Biggs. Computational Learning Theory - An Introduction. Cambridge University Press, 1992.

$\left[\mathrm{ABL}^{+} 94 \mathrm{a}\right]$ Bruce Alberts, Dennis Bray, Julian Lewis, Martin Raff, Keith Roberts, and James D. Watson. Molecular Biology of the Cell. Garland Publishing, Inc, 1994.

$\left[\mathrm{ABL}^{+} 94 \mathrm{~b}\right]$ Bruce Alberts, Dennis Bray, Julian Lewis, Martin Raff, Keith Roberts, and James D. Watson. Molecular Biology of the Cell. Garland Publishing, Inc, 1994.

[Adi00] Said Sadique Adi. Ferramentas de Auxilio ao Sequenciamento de DNA por Montagem de Fragmentos: um estudo comparativo. Master's thesis, Instituto de Matematica e Estatistica da Universidade de Sao Paulo, 2000.

[All] Lloyd Allison. Trie.

http://www.csse.monash.edu.au/ lloyd/tildeAlgDS/Tree/Trie.html.

[Ang82] Dana Angluin. Inference of reversible languages. Journal of the ACM, 29:741765, 1982.

[Ang88] Dana Angluin. Queries and concept learning. Machine Learning, 2:319-342, 1988.

[AS83] Dana Angluin and Carl H. Smith. Inductive inference: theory and methods. Computing Surveys, 15(3):237-269, 1983.

[AU72] Alfred V. Aho and Jeffrey D. Ullman. The Theory of Parsing, Translation, and Compiling, volume 1: Parsing. Prentice-Hall, Inc., Englewood Cliffs,NJ, 1972. 
[Bak79] J. K. Baker. Trainable grammars for speech recognition. Speech Communication Papers for the 97th Meeting of the Acoustical Society of America, pages 547-550, 1979.

[Bau72] L. E. Baum. An inequality and associated maximization technique in statistical estimation for probabilistic functions of markov processes. Inequalities, 3:1-8, 1972.

[BB01] Pierre Baldi and Soren Brunak. Bioinformatics: The Machine Learning Approach. MIT Press, 2001. Capítulo 11.

$\left[\mathrm{BLB}^{+}\right.$01] Ritu Banerjee, Jun Liu, Wandy Beatty, Lorraine Pelosof, Michael Klemba, and Daniel E. Goldberg. Four plasmepsins are active in the plasmodium falciparum food vacuole, including a protease with an active-site histidine. PNAS Earley Edition, 2001. http://www.pnas .org/cgi/10.1073/pnas. 022630099.

[CFS ${ }^{+}$02] Roland A. Cooper, Michael T. Ferdig, Xin-Zhuan Su, Lyann M. B. Ursos, Jianbing Mu, Takashi Nomura, Hisashi Fujioka, David A. Fidock, Paul D. Roepe, and Thomas E. Wellems. Alternative mutations at position 76 of the vacuolar transmenbrane protein pfcrt are associated with chloroquine resistence and unique stereospecific quinine and quinidine responses in plasmodium falciparum. Molecular Pharmacology, 65:35-42, 2002.

[Cho59] N. Chomsky. On certain formal properties of grammars. Information and Control, 2:137-167, 1959.

[CO97] Rafael C. Carrasco and Jose Oncina. Learning context-free grammars from stochastic structural information, 1997.

[DOE92] DOE Human Genome. Primer on Molecular Genetics, 1992. Program Report [http://www .ornl.gov/hgmis/publicat/primer/intro.html].

[Ear70] Jay Earley. An efficient context-free parsing algorithm. Communications of the ACM, 13(2):94-102, 1970.

[Fic96] James W. Fickett. The gene identification problem: an overview for developers. Computers Chem, 20(1):103-118, 1996. 
[Fla99] David Flanagan. Java in a Nutshell. O'Reilly, 1999.

[Fu82] King S. Fu. Syntactic Pattern Recognition and Applications. Prentice-Hall, Inc., Englewood Cliffs, NJ, 1982.

[GHJV99] Erich Gamma, Richard Helm, Ralph Johnson, and John Vlissides. Design Patterns - Elements of Reusable Object-Oriented Software. Addison Wesley, 1999.

[Gio94] Jean-Yves Giordano. Inference of context-free grammars by enumeration: Structural containment as an ordering bias. Lecture Notes in Computer Science, 862:212-221, 1994.

[Gol67] E. Mark Gold. Language Identification in the Limit. Information and Control, 10:447-474, 1967.

[HSF97] J. Henderson, S. Salzberg, and K. Fasman. Finding genes in DNA with a hidden Markov model. JCB, 4(2):127-142, 1997.

[HU79] John E. Hopcroft and Jeffrey D. Ullman. Introduction to Automata Theory, Languages, and Computation. Addison-Wesley Publishing Company, 1979.

[JS90] Cesar Silva Jr. and Sezar Sasson. Biologia 1. Atual Editora LTDA, 1990.

[Lee96] Lilian Lee. Learning of context-free languages: A survey of the literature. Technical report, Center of Research in Computing Technology, Harvard University, 1996.

[LJ78] Leon S. Levy and Aravind K. Joshi. Skeletal structural descriptions. Information and Control, 39:192-211, 1978.

[Lop91] Sonia Lopes. Bio - Livro Verde. Editora Saraiva, 1991.

[LY90] K. Lari and S. J. Young. The estimation of stochastic context-free grammars using the inside-outside algorithm. Computer Speech and Language, 4:35-56, 1990.

[Mak92] E. Makinen. On the structural grammatical inference problem for some classes of context-free grammars. Information Processing Letters, 42:193-199, 1992. 
[Mic93] Yasubumi Sakakibara Michael. The application of stochastic context-free grammars to folding, aligning and modeling homologous rna sequences. Technical report, University of California - Computer Science Department, 1993. Technical Report UCSC-CRL-94-14.

[Mäk98] Erkki Mäkinen. On inferring linear single-tree languages. Technical report, University of Tampere - Department of Computer Science, 1998. Technical Report A-1998-11.

[Mou00] Mariluce Moura. Pesquisa FAPESP, julho 2000. nr. 55, pags. 8-15.

[MS94] Joao Meidanis and Joao Carlos Setubal. Uma introducao a biologia computacional. In IX Escola de Computacao, Recife, 1994.

[NCB] NCBI. Fasta format description. http://www.ncbi.nlm.nih.gov/BLAST/fasta.html.

[NI00] Katsuhiko Nakamura and Takashi Ishiwata. Synthesizing context free grammars from sample strings based on inductive cyk algorithm. Lecture Notes in Artificial Intelligence, 1891:186-195, 2000.

[NSB00] Francisco Nevado, Joan-Andreu Sánchez, and José-Miguel Benedí. Combination of estimation algorithms and grammatical inference techniques to learn stochastic context-free grammars. Lecture Notes in Artificial Intelligence, 1891:196-206, 2000 .

[Sak90] Yasubumi Sakakibara. Learning context-free grammars from structural data in polynomial time. Theoretical Computer Science, 76:223-242, 1990.

[Sak92] Yasubumi Sakakibara. Efficient learning of context-free grammars from positive structural examples. Information and Computation, 97:26-60, 1992.

[Sak95] Yasubumi Sakakibara. Grammatical inference: an old and new paradigm. Lecture Notes in Artificial Intelligence, 997:1-24, 1995.

[Sak97] Yasubumi Sakakibara. Recents advances of grammatical inference. Theoretical Computer Science, 185:15-45, 1997. 
[Sal73] Arto Salomaa. Formal Languages. Academic Press, 1973.

[SBH ${ }^{+}$94a] Yasubumi Sakakibara, Michael Brown, Richard Hughey, I. Saira Mian, Kimmen Sjolander, Rebecca C. Underwood, and David Haussler. Recents Methods for RNA Modeling Using Stochastic Context-Free Grammars. In Proceedings of the Asilomar Conference on Combinatorial Pattern Matching, 1994.

[SBH+94b] Yasubumi Sakakibara, Michael Brown, Richard Hughey, I. Saira Mian, Kimmen Sjolander, Rebecca C. Underwood, and David Haussler. Stochastic context-free grammars for tRNA modeling. Nucleic Acids Research, pages 5112-5120, 1994.

[SBU+93] Yasubumi Sakakibara, Michael Brown, Rebecca C. Underwood, I. Saira Mian, and David Haussler. Stochastic context-free grammars for modeling RNA. Technical report, University of California - Computer Science Department, 1993. Technical Report UCSC-CRL-93-16.

[SBU+94] Yasubumi Sakakibara, Michael Brown, Rebecca C. Underwood, I. Saira Mian, and David Haussler. Stochastic context-free grammars for modeling RNA. In Proceedings of the Hawaii Conference on System Sciences. IEEE Computer Society Press, 1994.

[SD93] David Searls and Shan Dong. A syntatic pattern recognition system for DNA sequences. In Proceedings of the Second International Conference in Bioinformatics, Supercomputers and Complex Genome Analysis, pages 89-101, 1993.

[Sea92] David Searls. The linguistics of DNA. American Scientist, 80:579-591, 1992.

[Sea93] David Searls. String variable grammar: a logic grammar formalism for the biological language of DNA. The Journal of Logic Programming, 12:1-30, 1993.

[Sea97] David Searls. Linguistic approaches to biological sequences. CABIOS, 13(4):333$344,1997$.

[Sea99] David Searls. Formal language theory and biological macromolecules. Series in Discrete Mathematics and Theoretical Computer Science, 47:117-140, 1999.

[SF00] Jose M. Sempere and Antonio Fos. Learning linear grammars from structural information. Lecture Notes in Artificial Intelligence, 1891:126-133, 2000. 
[SM00] Yasubumi Sakakibara and Hidenori Muramatsu. Learning context-free grammars from partially structured examples. Lecture Notes in Artificial Intelligence, 1891:229-240, 2000.

[STSH00] Noriko Sugimoto, Takashi Toyoshima, Shinichi Shimozono, and Kuichi Hirata. Constructive learning of context-free languages with a subpansive tree. Lecture Notes in Artificial Intelligence, 1891:270-283, 2000.

[Tak88] Y. Takada. Grammatical inference for even linear languages based on control sets. Information Processing Letters, 28:193-199, 1988.

[TO00] Sophia Tsoka and Christos A. Ouzounis. Recent developments and future directions in computational genomics. FEBS Letters, 23897:1-7, 2000.

[Tom96] Nina Sumiko Tomita. Programação automática de máquinas morfológicas baseada em aprendizado PAC. Master's thesis, Instituto de Matematica e Estatistica da Universidade de Sao Paulo, 1996.

[Und94] Rebecca Christine Underwood. Stochastic Context-Free Grammars for Modeling Three Spliceosomal Small Nuclear Ribonucleic Acids. Master's thesis, Baskin Center for Computer Engineering and Information Sciences, University of California, 1994.

[Val84] L. G. Valiant. A Theory of the Learnable. Communications of the ACM, 27(11):1134-1142, 1984.

[Vie02] Daniel Cruz Gouveia Vieira. Construção de classificadores de seqüências genéticas utilizando gramáticas regulares. Não publicado., 2002.

[Yok91] T. Yokomori. Polynomial-time learning of very simple grammars from positive data. In Proceedings of Fourth Workshop on Computational Learning Theory, pages 213-227, 1991. 